\title{
ANALYSIS OF DATA FROM A DOWNHOLE OIL/WATER SEPARATOR FIELD TRIAL IN EAST TEXAS
}

\section{Topical Report}

February 2001

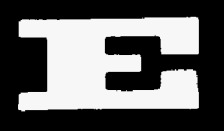

By:

John A. Veil

Arthur Langhus Layne

Date Published: April 2001

Work Performed Under Contract No. FEW 49397

Argonne National Laboratory

Washington, DC

\section{National Energy Technology Laboratory National Petroleum Technology Office U.S. DEPARTMENT OF ENERGY Tulsa, Oklahoma}




\section{DISCLAIMER}

This report was prepared as an account of work sponsored by an agency of the United States Government. Neither the United States Government nor any agency thereof, nor any of their employees, makes any warranty, expressed or implied, or assumes any legal liability or responsibility for the accuracy, completeness, or usefulness of any information, apparatus, product, or process disclosed, or represents that its use would not infringe privately owned rights. Reference herein to any specific commercial product, process, or service by trade name, trademark, manufacturer, or otherwise does not necessarily constitute or imply its endorsement, recommendation, or favoring by the United States Government or any agency thereof. The views and opinions of authors expressed herein do not necessarily state or reflect those of the United States Government.

This report has been reproduced directly from the best available copy. 
DOE/FEW 49397-2

Distribution Category UC-122

Analysis of Data from a Downhole Oil/Water Separator Field Trial in East Texas

April 2001

Work Performed Under Contract FEW 49397

Prepared for

U.S. Department of Energy

Assistant Secretary for Fossil Energy

Nancy Comstock, Technology Manager

National Petroleum Technology Office

P.O. Box 3628

Tulsa, OK 74101

Prepared by

Argonne National Laboratory

955 L'Enfant Plaza SW

Suite 6000

Washington, DC 20024 


\section{Table of Contents}

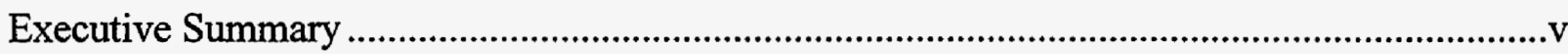

Chapter 1 - Introduction................................................................................................................

Chapter 2 - Description of DOWS.....................................................................................................

Chapter 3 - Description of the Well and DOWS Installation...................................................................7

Chapter 4 - Well Performance before DOWS Installation ………............................................................9

Chapter 5 - Well Performance Following DOWS Installation ...............................................................11

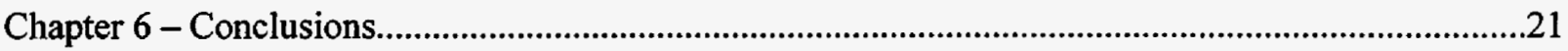

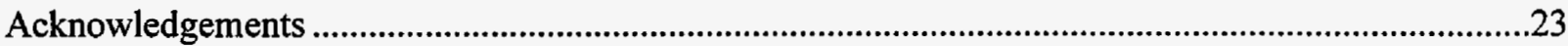

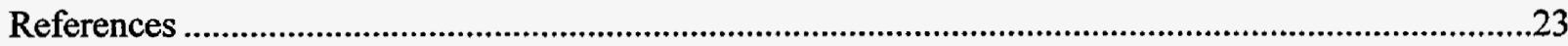

Tables

Table 1 - Daily Production and Operations Data.....................................................................25-42

Table 2 - Production and Productivity Index ..............................................................................43

Table 3 - Production Summary: October 29 to November 15, 1998 ...........................................43

Table 4 - Calculated Injection and Recycled Volumes................................................................43

Table 5 - DOWS Production Statistics.....................................................................................44

Figures

Figure 1 - Oil and Water Production During DOWS Trial.........................................................45

Figure 2 - Injection Parameters 10/29/98-11/18/98 ...................................................................46

Figure 3 - Pressure Data 10/29/98-11/18/98 ...........................................................................47

Figure 4 - Pressure and Oil Cut Data 10/29/98-11/18/98 ……..................................................48

Figure 5 - Additional Injection Parameters 10/29/98-11/18/98_.................................................49

Figure 6 - Injection Parameters 11/19/98-11/29/98 ………….................................................50

Figure 7 - Annulus Pressure 11/19/98-11/29/98 ………………...............................................

Figure 8 - Injection Rate and Annulus Pressure 11/20/98-12/1/98............................................52

Figure 9 - Injection Rate and Annulus Pressure 12/1/98-12/7/98.............................................53

Figure 10 - Apparent Injectivity 12/1/98-12/7/98.................................................................54

Figure 11 - Injection Parameters 3/11/99-3/16/99 ....................................................................5

Figure 12 - Injectivity $3 / 1$ 1/99-3/16/99..............................................................................56

Figure 13 - Injection Parameters 3/11/99-12/2/99 ....................................................................57

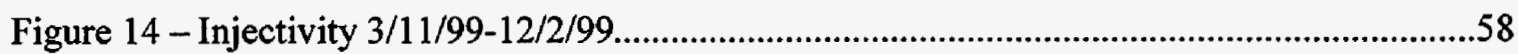

Figure 15 - Oil and Water Production to the Surface 3/11/99-12/2/99 .........................................59

Figure 16 - Data from Tracer Study.....................................................................................60

Figure 17 - Oil Cut During DOWS Installation..........................................................................61 


\section{Executive Summary}

Downhole oil/water separator (DOWS) technology is available to separate oil from produced water at the bottom of an oil well. Produced water can be injected directly to a disposal formation rather than lifting it to the surface, treating it there, and reinjecting it. Because of a lack of detailed performance data on DOWS systems, the U.S. Department of Energy (DOE) provided funding to secure DOWS performance data. A large U.S. oil and gas operator offered to share its data with Argonne National Laboratory. This report summarizes data from that DOWS installation in eastern Texas.

A REDA AQWANOT hydrocyclone-type DOWS was installed in the candidate well on October 28,1998 . Prior to installation of the DOWS, the well was producing 43 barrels per day (bpd) of oil and 3,384 bpd of water to the surface. The initial performance of the DOWS was encouraging. From October 29 to November 15, the well produced $43.1 \mathrm{bpd}$ of oil and only $448 \mathrm{bpd}$ of water to the surface. This represents an $87 \%$ reduction in water to be handled at the surface, while maintaining the same volume of oil. At the end of this period, the injection pressure had increased to undesirable levels and the well was shut in and acidized.

Following acidization, the well was returned to service, but it produced limited quantities of oll and water to the surface during the period of November 18, 1998 to February 17, 1999 , at which time the DOWS unit was removed from the well. It is interesting to note that although surface production was low, the oil cut was quite high (70\%) during this period

Upon inspection of the DOWS, it was apparent that the tubing below the DOWS unit was badly corroded, presumably by the November acid treatment. The holes in the tubing allowed fluids to return to the producing formation rather than being injected to the disposal formation. Although the DOWS processed a large volume of fluids, little of it was successfully injected or produced to the surface.

The DOWS was reinstalled on March 11, 1999 with new tubing. From that date until December 10,1999, the DOWS performed adequately. Oil production was erratic, varying from $3 \mathrm{bpd}$ to more that $20 \mathrm{bpd}$, but was still well below the pre-DOWS production levels. Water production to the surface was much lower than it had been in the pre-DOWS trial - about 250-350 bpd. During September 1999, the operator conducted a dye tracer study to look for recycling of injected water to the producing zone. The tracer study found that about $50 \%$ of the injected water was being recycled rather than disposed. The DOWS trial was discontinued on December 11 and the DOWS was removed from the well the following February.

The trial was not an economic success, but the operator was able to gain valuable experience from the trial nonetheless. The Promore instrumentation package allowed the operators to get a clearer idea of what was happening downhole. Problems with injectivity, acidization, and recycling should lead to better designs, installations, and operating practices on future DOWS. 


\section{Chapter 1 - Introduction}

The U.S. Department of Energy's (DOE's) National Petroleum Technology Office (NPTO) is interested in promoting new technologies that can produce oil and gas at a lower cost or with enhanced environmental protection at a reasonable cost. Several years ago, DOE became aware of a new technology for produced water management known as a downhole oil/water separator (or DOWS). A DOWS system separates oil from water at the bottom of a production well and injects the water directly to a disposal zone without lifting it to the surface. DOWS technology offered three potential advantages over traditional pumping systems. First, DOWS were reported to reduce the volume of produced water brought to the surface. Second, the volume of oil produced often increased. Third, because large volumes of produced water were not being lifted to the surface past drinking water zones and subsequently reinjected downward past the same drinking water zones, there was less opportunity for contamination of those zones.

DOE provided funding to Argonne National Laboratory (Argonne) to conduct an independent investigation of the technical feasibility, legality, and economic viability of the DOWS technology. Argonne, in conjunction with $\mathrm{CH} 2 \mathrm{M}-\mathrm{Hill}$ and the Nebraska Oil and Gas Conservation Commission, issued a final report on that investigation in January 1999 (Veil et al. 1999). Although the report provides considerable general information about DOWS, most operators were not willing to share the detailed day-by-day operating data on their systems. To obtain more data to share with other interested operators and to better understand how DOWS work, DOE made additional funding available to Argonne to collect detalled operating data from up to six field trials of new DOWS installations.

A large U.S. oil and gas operator installed a DOWS system in a well in eastern Texas in 1998 and ran it for about 16 months. The operator did not initially participate in the Argonne/DOE DOWS field trial program but later offered data on the well to Argonne in exchange for having the data analyzed. This summary report examines the DOWS installation and operation and associated well data.

Most of the data analysis provided in this report was performed by Bruce Langhus of Arthur Langhus Layne-LLC. Dr. Langhus was formerly employed by $\mathrm{CH} 2 \mathrm{M}-\mathrm{Hill}$ when the DOWS feasibility study (Veil et al. 1999) was prepared and was one of the principal investigators for that study. 



\section{Chapter 2 - Description of DOWS}

\section{How a DOWS Works}

The DOWS technology reduces the quantity of produced water that is handled at the surface by separating it from the oil downhole and simultaneously injecting it underground. The two primary components of a DOWS system are an oil/water separation system and at least one pump to lift oil to the surface and inject the water underground. Two basic types of DOWS have been developed - one type using hydrocyclones to mechanically separate oil and water and one relying on gravity separation that takes place in the well bore.

Hydrocyclones use centrifugal force to separate fluids of different specific gravity without any moving parts. A mixture of oil and water enters the hydrocyclone at a high velocity from the side of a conical chamber. The subsequent swirling action causes the heavier water to move to the outside of the chamber and exit through one end, while the lighter oil remains in the interior of the chamber and exits through a second opening. The water fraction is then injected, and the oil fraction is pumped to the surface. Hydrocyclone-type DOWS have been designed with electric submersible pumps, progressing cavity pumps, and rod pumps. Most of the development work on this type of DOWS was done through several joint industry projects by a Canadian organization, CFER-Technologies.

Gravity separator-type DOWS are designed to allow the oil droplets that enter a well bore through the perforations to rise and form a discrete oil layer in the well. A gravity separator tool has two intakes, one in the oil layer and the other in the water layer. The gravity separator-type DOWS use rod pumps. As the sucker rods move up and down, the oil is lifted to the surface and the water is injected. The most common gravity separator-type DOWS is the dual-action pumping system (DAPS) developed by Texaco.

\section{Advantages of a DOWS System}

The costs of lifting, treating, and disposing of produced water are important components of operating expenses. DOWS can save operators money by reducing produced water management costs. In all of the 29 DOWS installations examined by Veil et al. (1999) for which both pre- and post-installation data were available, DOWS reduced the volume of water brought to the surface. The percent reduction of produced water ranged from 14 to $97 \%$, with most installations exceeding $75 \%$ reduction.

In over half of the North American wells in which DOWS have been installed, the oil production rates increased following the installation. The percent increase ranged from $11 \%$ to over $1,100 \%$, although a few wells lost oil production (Veil et al. 1999). In some cases where surface processing or disposal capacity for produced water is a limiting factor for further production within a field, the use of DOWS to dispose of some of the produced water may allow additional production in that field.

DOWS provide a positive but unquantifiable environmental benefit by minimizing the opportunity for contamination of underground sources of drinking water through leaks in tubing and casing during the injection process. Likewise, DOWS minimize spillage of produced water onto the soil at the surface because less produced water is handled at the surface. 


\section{Economic Considerations}

Nearly all of the DOWS installations to date have been made as retrofits to existing wells with standard pumps. Conversion of a well from a regular pump to a DOWS is a relatively expensive undertaking. Total costs include the cost of the DOWS tool itself and well workover expenses. Veil et al. (1999) provide some information on costs, but many of the operators polled by the authors did not provide detailed cost information.

Costs for the hydrocyclone-type DOWS are high. For example, the cost of an electric submersible pump-type DOWS system is approximately double to triple the cost of replacing a conventional electrical submersible pump and is often in the range of $\$ 90,000-\$ 250,000$. In addition, the associated well workover costs can often exceed $\$ 100,000$. Costs are somewhat lower for the gravity separator-type DOWS, ranging from $\$ 15,000-\$ 25,000$. The cost of one complete gravity separator-type DOWS installation was $\$ 140,000$ Canadian (Veil et al.1999).

\section{Summary Statistics on North American Installations of DOWS}

As of 1999, fewer than 50 DOWS had been installed worldwide. Veil et al. (1999) provide information on the geology and performance of 37 of those installations. Some of the key findings are summarized below:

- More than half of the installations have been hydrocyclone-type DOWS (21 compared with 16 gravity separator-type DOWS).

- Twenty-seven installations have been in Canada and 10 have been in the United States.

- Of the 37 DOWS trials described, 27 have been in four producing areas - southeast Saskatchewan, east-central Alberta, the central Alberta reef trends, and East Texas.

- Seventeen installations were in 5.5-inch casing, 14 were in 7-inch casing, 1 was in 8.625inch casing, and 5 were unspecified.

- Twenty of the DOWS installations have been in wells located in carbonate formations and 16 have been in wells located in sandstone formations. One trial did not specify the lithology. DOWS appeared to work better in carbonate formations, showing an average increase in oil production of $47 \%$ (compared with an average of $17 \%$ for sandstone formations) and an average decrease in water brought to the surface of $88 \%$ (compared with $78 \%$ for sandstone formations).

- The rate of oil production increased in 19 of the trials, decreased in 12, stayed the same in 2 , and was unspecified in 4 . The top three performing hydrocyclone-type wells showed oil production increases ranging from $457 \%$ to $1,162 \%$, while one well lost all oil production. Production in the top performing well improved from 13 to 164 barrels per day (bbl/d). The top three gravity separator-type wells showed oil production increases ranging from $106 \%$ to $233 \%$, while one well lost all oil production. In terms of percent of increase, the top performing well in this group improved from 3 to $10 \mathrm{bbl} / \mathrm{d}$.

- All 29 trials for which both pre-installation and post-installation water production data were provided showed a decrease in water brought to the surface. The decrease ranged from $14 \%$ to $97 \%$, with 22 of 29 trials exceeding $75 \%$ reduction. 


\section{What Problems Have Been Experienced}

Although most of the DOWS installed to date have worked well, some of the installations have experienced problems. The problems can be broken down into several major categories, as summarized below:

- Some installations were poorly chosen or designed. Some operators didn't want to risk damaging good performing wells with a new device, so they selected less than optimal candidate wells. Particularly in the earliest installations, many of the system design flaws had not been worked out. Subsequent models avoided some of these flaws.

- Some installations did not allow a suitable difference in depth between the producing and the injection interval. If isolation between the intervals is not sufficient, the injectate can migrate back into the producing zone and then short-circuit into the producing perforations. The result will be recycling of the produced water, with oil production rates dropping to nearly zero.

- Two installations suffered from low injectivity of the receiving zone; in both cases, incompatible fluids contacted sensitive reservoir sands, which plugged part of the permeability.

- Several installations suffered from corrosion or scaling. This problem may be a result of incompatible chemistry between the producing and injection formations.

- Several other installations had problems with excessive sand collection that either clogged or eroded the DOWS. 


\section{Chapter 3 - Description of the Well and DOWS Installation}

A DOWS system was installed in a well in a large oil field in eastern Texas that has produced over 485 million barrels (bbl) of oil since its discovery in 1929. Most of the production has been from the Woodbine Formation, although minor production occurs in both deeper and shallower formations. The petroleum occurs in the Cretaceous Woodbine sands, which extend across a broad, faulted anticline that seals and traps the crude oil. The Cretaceous-age reservoir is a clean, very porous, and permeable sand that averages $29 \%$ porosity and 1,000 millidarcies (md) permeability (Galloway et al. 1983). Several fluvial and deltaic sands contain oil across the trap. Initial water saturations were extremely low (9\%). Oil gravity was medium - approximately $34^{\circ}$.

The Woodbine consists of the lower Dexter Member and the upper Lewisville Member. The Dexter sands are more laterally extensive and more productive than the Lewisville. (In the subject well, only the Dexter " $\mathrm{C}$ " and " $\mathrm{B}$ " sands were perforated. The lower " $\mathrm{C}$ " serves as injection zone and the " $\mathrm{B}$ " as producing zone.)

The DOWS unit was installed in the subject well in 1998. However, it was not the first well to be equipped with a DOWS. In the past few years, four wells in the adjacent East Texas field have been recompleted as DOWS wells using gravity separators. The East Texas wells were all low flowing, averaging 8 barrels of oil and 226 barrels of water per day. Results with the gravity separator-type DOWS units in the East Texas field have been generally good (averaging $112 \%$ increase in oil and $41 \%$ decrease in water production) but not uniform. The field in which the subject well is located produces from a similar sand but is a structural rather than stratigraphic trap. The subject well is the first well in the eastern Texas area to use a hydrocyclone-type DOWS. It is the highest producing well in the area to be converted to DOWS; it produces the most water and most oil per day.

A REDA AQWANOT ${ }^{\mathrm{TM}}$ hydrocyclone-type DOWS unit was installed in the subject well. The unit was equipped with a REDA model DN4000, $150 \mathrm{hp}$ pump with variable speed drive. No added production pump was used. The installation included a $1 / 4$-inch coiled capillary sample tube and full downhole instrumentation. The DOWS equipment was engineered to fit inside the 5.5 -inch, 15.5-pound casing with $27 / 8$-inch tubing. The unit was fitted to a 5.5-inch Seal Bore packer at a depth of 2815 feet. Production perforations were located at 2,633 to $2,635 \mathrm{ft}$ and 2,756 to 2,762 $\mathrm{ft}$; approximately 8 feet of the reservoir was perforated at eight shots per foot.

A full Promore ${ }^{\mathrm{TM}}$ downhole instrument package has been run in the well with excellent results, except for damage to the capillary tube during a work-over. Pressure sensors read the annulus pressure, as well as the pressure before the fluids enter and after they exit the hydrocyclone. This latter value is presumed to equal the injection pressure. The sensors have functioned well since the first day the bottom-hole assembly was installed (June 19, 1998). In addition, surface production records are available for oil and water production since start-up. These data can easily be compared to the data obtained from the downhole instrument package to complement the interpretation of performance and production. The subject well was thoroughly tested both before and after installation of the DOWS equipment. 


\section{Chapter 4 - Well Performance before DOWS Installation}

Information provided by the operator indicated that before the DOWS installation, the producing zone had a static pressure of 955 psi and a maximum fluid rate of 27,261 barrels per day (bpd). Production on October 27,1998 , totaled 3,383 bpd of water and 43 bpd of oil. Thus, the oil production (or oil cut) amounted to $1.27 \%$ of the fluids produced. The injection zone perforations were from 2,822 to $2,834 \mathrm{ft}$, with a static reservoir pressure of 905 pounds per square inch (psi) and a pre-DOWS injectivity index of $7.6 \mathrm{bpd} / \mathrm{psi}$. Oll measured $34.5^{\circ} \mathrm{API}$ gravity. Reservoir temperature was $144^{\circ} \mathrm{F}$. These data were supplied by the operator to REDA to provide the basis for design of the DOWS unit. However, when the unit was actually installed, the well conditions were somewhat different, as measured by the downhole instruments:

1. Producing zone was found to have static pressure of 830 psi instead of 955 psi.

2. Injection zone was found to have static pressure of 910 psi instead of 905 psi

3. Injectivity was measured in a step-rate test as being between 3.4 and $4.8 \mathrm{bpd} / \mathrm{psi}$ instead of the $7.6 \mathrm{bpd} / \mathrm{psi}$ as reported. 



\section{Chapter 5 - Well Performance Following DOWS Installation}

Production rates were highly variable in the subject well during the months of operation following DOWS installation. As indicated by the selected history summarized below, the operation with the DOWS in place was less than optimal:

1. April 1, 1998:

2. June 19, 1998:

3. June 19, 1998:

4. October 29, 1998:

5. November 15, 1998:

6. November 18, 1998:

7. February 17, 1999:

8. March 9, 1999:

9. September 8-12, 1999:

10. February 2000:
Pre-installation step-rate injectivity test

Start-up test of DOWS installation (2 hours duration)

Fall-off test conducted after shut-down of DOWS equipment

Sampled injectate at DOWS system restart; system operates for 17 days until injection pressure builds to undesirable levels.

Well shut-in for acidization of injection zone.

Well resumes operations, injectivity values appear to be extremely high and production rates to the surface were very low.

DOWS unit was shut-in, tubing found to be corroded. DOWS unit was re-run in the hole with new tubing; operation shows significant oil and water production to the surface and injectivity values similar to pre-DOWS levels. Tracer survey documented significant fluid movement behind production casing.

DOWS unit is pulled from the well.

Table 1 shows a daily compilation of production and DOWS parameters derived from downhole instrumentation. Figure 1 is a graphical depiction of the production data. Production and operating parameters are discussed in detail below for specific periods of operation.

\section{Operations Data: Start-up - October 29 to November 18, 1998}

Although a 2-hour test of the DOWS setup was conducted on June 19,1998, full-scale operation of the unit did not began until October 29. During the start-up period, the following downhole data were collected every 5 seconds: borehole pressure, upstream pressure, injection pressure, and injection rate. In addition, injectivity can be computed for every 5 seconds, and surface production rates were recorded once per day. During this portion of the field trial, the downhole instruments provided good data.

Summary Interpretation: The available downhole data and surface production data for this period provide considerable information relative to gross production, oil cut changes, injection zone plugging, possible injection zone fracturing, and possible recycling of water behind production casing. Volumes of proprietary data were reviewed to develop the interpretations discussed here.

Downhole and surface data show deterioration in injectivity as operations continue, indicating gradual plugging of the injection zone. The data indicate a steady increase in borehole pressure, indicating possible circulation of injectate behind the casing into the producing zone. 
Good data on sustained decay of injectivity were seen between October 29 and November 5 . as shown in Figure 2. The graph shows five cycles of injection separated by pump shutdown. Each cycle begins with relatively low injection pressure and high injectivity and ends with high injection pressures and low injectivity values. As the cycles progress, starting and ending pressures increase and injectivity values decrease.

Injectivity decreased from approximately $3.0 \mathrm{bpd} / \mathrm{psi}$ to less than $0.8 \mathrm{bpd} / \mathrm{psi}$. This injectivity trend was a recurring phenomenon and was most likely due to partial plugging of the reservoir near the borehole by fines contained in the injectate. The presence of fines and crude oil in the injectate was documented by the operator during the April 1998 injectivity test and the June 19 start-up test of the injectate recovered via the capillary tube. Assuming a 175-ppm combined load of fines and oil in the injectate and a variable injection rate between 4,000 and $1,600 \mathrm{bpd}$, the weight of plugging material injected during that time varied from 94 to $235 \mathrm{lb} /$ day. About $80 \%$ of the fines exceeded $10 \mu \mathrm{m}$ in diameter and were composed primarily of quartz. It is likely that these silt-sized particles plugged pore-throats near the borehole. Although the injection reservoir appeared to be plugging off, the rate of decrease flattened at approximately $0.70 \mathrm{bpd} / \mathrm{psi}$, compared with injectivity values that dropped below $0.40 \mathrm{bpd} / \mathrm{psi}$ during the June 19,1998 , short-lived test of the DOWS unit. Whether injectivity would have continued to decline or would have stabilized at $0.70 \mathrm{bpd} / \mathrm{psi}$ is unknown. During the period graphed in Figure 2, the injectivity curve showed no signs of fracturing, even though injection pressures were very high.

Fracture pressure was determined to be approximately $1,800 \mathrm{psi}$ (surface pressure) during the April 1, 1998, step-rate injectivity test. During that test, injection pressure reached 1,871 psi with a rate of 5,760 bpd. An unknown section of the injection zone (Woodbine " $\mathrm{C}$ ") was used for the step-rate injection test. After installation of the DOWS equipment, surface injection pressures reached a plateau during the June 19 trial at approximately 2,500 psi with no signs of fracturing. Later, after the well was worked over and the DOWS equipment reinstalled, injection pressures increased as shown in Figure 3.

Injection pressures regularly exceeded the estimated fracture pressure of the receiving interval (Figure 3); however, no sign of fracturing is seen until November 5 . This situation is further evidence of plugging of the injection zone - the significant pressure drop across the sand face protected the formation and prevented fracturing. Late on November 5,1998 , injection broke through to the producing zone either through a hole in the injection tubing below the hydrocyclone or behind the casing to connect the injection zone and the producing zone. The immediate effect was elevation of the annulus pressures above the static reservoir pressure of approximately $830 \mathrm{psi}$. Injectivity did not appear to change after the breakthrough, suggesting that the path between the injection and production zones was tortuous and restricted, such as a microannulus in the cement behind the casing. This condition continued until November 15 , when the injection zone was acidized.

When interpreting the data around November 5 , one must keep in mind that annulus pressure is caused by the following factors:

1. Static reservoir pressure communicating through the perforations,

2. Withdrawal rate as controlled by the DOWS pumping from the annulus, 
3. Leakage of injectate from the tubing into the annulus, and

4. Recycling of injectate from the injection zone into the production zone in the vicinity of the borehole.

The pressure/oil cut plot (Figure 4) also shows daily production figures; these numbers do not show the clear correlation between low borehole pressure and higher oil cuts that would be expected. Pre-DOWS production stood at a total oil cut of $1.27 \%$ (43 bpd of oil and $3,384 \mathrm{bpd}$ of water). That oil cut was exceeded throughout the DOWS start-up test, although produced oil was often less than $43 \mathrm{bpd}$. The high oil cut level at the beginning of the DOWS trial was very likely due to draw down of accumulated oil in the borehole. The similarly high initial oil cut following the restart of the pump early on November 2, 1999, may also have been due to production of oil that had accumulated in the borehole. The lack of correlation between borehole pressure and oil cut may be due to intermittent recycling of salt water from the injection zone into the producing zone.

Detailed Operational Parameters: An expanded set of operational parameters covering the period from October 29 to November 18 provides a nearly complete data set. While the DOWS unit was operating, downhole parameters stabilized so that injection pressures held at approximately $2,520 \mathrm{psi}$ and injectivity stabilized at approximately $0.54 \mathrm{bpd} / \mathrm{psi}$. However, beginning on November 5, mechanical problems caused injection pressure to drop to hydrostatic levels while the injection rate dropped to zero for varying periods of time. During this operating period, increased injection pressure was transmitted to the borehole above the packer, suggesting a degree of connection either across the packer or behind the production casing.

Injection pressures (Figure 3) fluctuated from well above fracture pressure (stabilizing at 2,556, 2,528 , and $2,544 \mathrm{psi}$ ) to near the formation pressure of the injection zone (approximately $910 \mathrm{psi}$ ). Injection pressure cycling was a function of intermittent pump shutdown due to an unknown cause. On November 15, the well was shut-in to acidize the injection zone; an acid treatment of unknown volume was poured into the annulus of the well. Immediately after acidizing, injection pressure dropped to static except during a brief, moderate-pressure pump off. From after acidization through the end of the period, injection pressure never exceeded fracture pressure.

The injection rate data documented gradual plugging of the injection zone; this situation was further indicated by the cyclic changes in injectivity as operations continued (Figure 5). Injection rates stabilized at approximately $1,478,1,446,1,385$, and $1,331 \mathrm{bpd}$ as injection progressed in cycles. As was pointed out above, the fracturing noted on November 5 is barely discernable on the injection rate graph. During pump-off operations on November 18,5-second rates as high as 7,652 bpd were measured.

Injectivity was measured prior to the DOWS installation at between 3.4 and $4.8 \mathrm{bpd} / \mathrm{psi}$. Relatively stabilized injectivity during this period of operations (Figure 5) declined from $0.61 \mathrm{bpd} / \mathrm{psi}$ to $0.51 \mathrm{bpd} / \mathrm{psi}$; apparently as a result of continued plugging at the sand face. The acid slug was placed in the hole at 8:00 a.m. on November 15 and remained there until 9:00 a.m. on November 18, when the DOWS pump was run for approximately one hour at very high speeds to pump away the acid. The period of erratic high-rate injection on November 18 was the only example of injectivity displaying evidence of fracturing of the injection formation. During that short period, injectivity increased to over $8.0 \mathrm{bbl} / \mathrm{psi}$ from its stabilized (pre-acidization) value of less than $0.6 \mathrm{bbl} / \mathrm{psi}$. Throughout the November 18 episode, however, injection 
pressures never exceeded the fracture pressure. In summary, it seems most likely that fracturing was not occurring during November 18 , but rather that the very high injectivity rates were due to acid corrosion and perforation effects upon the injection zone and upon the tubing above the packer.

Annulus pressure and injection pressure were closely correlated during most of this period (Figure 3); initial pressure was drawn down by production, but pressure soon increased as injection rate decreased. This is the expected behavior of pressure in the borehole - initial static value followed by low drawdown pressure that gradually increases as borehole fluid level stabilizes at a higher and higher value, always below the static level and pressure. The borehole pressure displayed expected behavior during two cycles of zero injection: (1) pressure was stabilizing at values in excess of 824 psi in the operational cycle from October 29 to November 2 (approximately 14-foot fluid-level drop); and (2) pressure stabilized at 827 psi during the cycle from November 2 to November 6 (approximately 7-ft fluid-level drop). The productivity index can be calculated by relating withdrawal rates to pressure drops in Table 2. The average productivity index was $442 \mathrm{bpd} / \mathrm{psi}$.

The data summarized in Table 2 are for the period when the DOWS installation was operating correctly - injection was not connected with the annulus above the packer. Later, on November 6 , borehole pressure began to exceed static values, reaching a high of about 833 psi on November 15, when injection pressure had stabilized at approximately $2,540 \mathrm{psi}$. When the injection rate went to 0 for an extended period of time, the borehole pressure decreased to approximately 828 psi, suggesting a close connection between the borehole above the packer and the injection zone. When injection pressures and rates increased briefly, borehole pressures spiked at the same time, further supporting the idea of communication between the injection zone and the annulus.

Oil and water production during the period October 29 to November 15 totaled $6,723 \mathrm{bb}$ water and $647 \mathrm{bbl}$ oil brought to the surface during 15 days of DOWS operation and 18 days total elapsed time. Production statistics shown in Table 3 compare pre-installation and postinstallation conditions. The DOWS production data are presented in two ways - (1) production to the surface only and (2) total production (oil and water to the surface plus water injection). Total production is a measure of the ability of the reservoir to give up fluid, while surface production is a measure of separation efficiency. The increased total oil cut produced with DOWS may have been caused by the idle time prior to start-up that allowed oil to collect near the borehole. Increased pumping efficiency with DOWS equipment usually translates to increased fluid production, but because of decreased injectivity, less total fluid was produced into the borehole, and that factor reduced oil production. The average decrease in water to the surface was $87 \%$, very similar to historical field trials elsewhere in the United States and Canada.

\section{Acidization of Injection Zone: November 16, 1998}

Sustained, cyclic plugging of the injection zone between October 29 and November 15 was obvious in the Promore data. In an effort to alleviate the problem, the well was acidized down the annulus with the DOWS assembly in place. No records of the acidizing procedure were maintained, but acid was not flushed for an extended period of time, which caused corrosion and perforation of the tubing. This damage was not seen until February 17, 1999, when the DOWS bottom-hole assembly was pulled from the well. 


\section{Operations Data: November 19 and November 20, 1998}

Data from operations during the two days following the acidization showed hydrostatic pressure on the injection zone and stable pressure on the producing zone. The ability of the injection zone to accept salt water after that period was apparently greatly increased, although no fluids were lifted to the surface.

Injection pressure (Figure 6) during these two days was significantly less than sustained rates experienced before. Except for instantaneous excursions, pressures stabilized at approximately $878 \mathrm{psi}$, which is about 32 psi below the static reservoir pressure measured in falloff tests and seen in no-flow points during operation of the DOWS unit. The acidization of the injection zone could explain the drop in reservoir pressure at the borehole if communication was established with another zone. A much more likely explanation is that tubing was corroded by the acid, allowing the injection stream to communicate with the annulus above the packer. In this scenario, the produced fluids would exit the hydrocyclone and be pumped back into the top of the hydrocyclone, with relatively little fluid being pumped into the injection zone. Apparent injection rates (rates measured by the instrumentation package) stabilized at levels much higher than seen previously during the DOWS trial. Rates varied from approximately 4,550 to $4,800 \mathrm{bpd}$, however, part of the water was likely injected back into the producing formation. Injection and recycle rates can be estimated from annulus pressures during operation.

Annulus pressure (Figure 7) remained stable at approximately 827 psi except for a short time when the pressure held at approximately $823 \mathrm{psi}$. These pressures most likely represent drawdown of the producing zone and injection of a portion of the fluid. A dynamic reservoir pressure of 827 psi represents a pressure drop of 3 psi from static pressure. Using the productivity index calculated above, this equates to a withdrawal of approximately $1,300 \mathrm{bpd}$. It would seem then that the remaining 3,250 to $3,500 \mathrm{bpd}$ of produced fluid was being recycled into the producing formation. No fluids were produced to the surface during these two days because of the very low operating pressures.

\section{Operations Data: November 20 to December 1, 1998}

Operations during the period November 20 to December 1, 1998, included apparent low pressure-high injection rates. Injectivity and the injection rate were extremely high, demonstrating that the tubing had been damaged by the acidization. Because injection pressures were low, very little water or oil was produced to the surface throughout this period.

Injection pressure remained in the range 860 to 920 psi. Pressure rose from approximately $880 \mathrm{psi}$ at the beginning of the period to approximately $910 \mathrm{psi}$ on November 27 . The pressure then dropped and varied from approximately 860 to $890 \mathrm{psi}$.

Injection rates varied from 4,400 to 4,900 bpd during this period of operation. The rates do not appear to depend on injection pressure during this period. Indeed, in several periods, the rate actually decreased as pressure increased (e.g., November 20 through November 24).

Annulus pressure varied between approximately 828 and 821 psi and appeared to be inversely related to injection (Figure 8 ) in that high apparent rates of injection occurred during periods of low pressure within the well bore. Annulus pressure can be used to calculate estimated volumes of fluid injected and recycled, as shown in Table 4. 
Production rate includes salt water injected into the injection perforations and salt water recycled into the annulus through corroded tubing. Annulus pressure drawdown is related to production through the productivity index calculated in Table 2. As shown in Table 4, annulus pressure as measured by the Promore unit determines net production. The recycled volume is calculated by subtracting net production from the total production. Actual injection volume was not, therefore, related to injection pressure, and recycling was apparently variable.

Production of fluids to the surface was insignificant. Because of the very low operating pressures, a total of only $49 \mathrm{bbl}$ of oil and $38 \mathrm{bbl}$ of salt water were produced to the surface during this period of operation.

\section{Operations Data from December 1, 1998 to January 8, 1999}

Operations continued with varying amounts of recycling through perforations in the tubing above the packer. Only small amounts of fluid were produced to the surface during the period December 1, 1998, to January 8,1999 (14.2 bpd of oil and $2.0 \mathrm{bpd}$ of water), but the oil cut from these fluids was quite high (87\%). Large volumes of fluid were processed in the hydrocyclone, but only part of the output was injected into the disposal zone.

Injection pressures varied between approximately 870 psi and 940 psi; the majority of the period was spent injecting at pressures less than the static reservoir pressure of the injection zone. During several periods of pump shutdown, the injection zone showed a static pressure of approximately 919 psi (December 21-31 and January 3); this value is approximately 9 psi over the static reservoir pressure measured as late as November 18 during the acid job. Injection reservoir pressure was measured at 909 psi on March 11, 1999; this measurement was taken after less than 5 minutes of shut-in, and the true static reservoir pressure may be different.

Measured injection rates (Figure 9) followed a common pattern during the period - the rate typically began at a low level, gradually increased, stabilized, then finally fell off. The rates ranged from about 4,400 to 4,800 bpd. A typical cycle is noted in Figure 9 between December 5 and 6,1998 . These cycles were repeated numerous times during the period. The sharp drop in injection rate at the end of each cycle was perhaps due to changes in power to the electric submersible pump, but information is not available to confirm this possibility. Injection pressure did not show similar cycles, but the pattern was repeated in the annulus pressure data (Figure 9).

Apparent (measured) injectivity (Figure 10) was in a limited range, most of the time from 5.0 to $5.40 \mathrm{bpd} / \mathrm{psi}$, slightly higher than measured prior to installation of the DOWS unit and approximately 10 times the levels seen during the early part of the DOWS trial before acidization of the injection zone. However, true injectivity (as calculated in Table 4) varied from 3.3 to $4.1 \mathrm{bpd} / \mathrm{psi}$, almost identical to that measured prior to the DOWS installation ( 3.4 and $4.8 \mathrm{bpd} / \mathrm{psi})$.

Annulus pressure ranged between 820 and 833 psi during this period of operation. This range represents approximately 3,000 to 3,500 bpd that was actually injected, the remainder of the fluid (approximately $1,500 \mathrm{bpd}$ ) being recycled into the producing formation through holes in the tubing. 


\section{Operations Data from January 9 to February 17, 1999}

Production from January 9-25 continued to be very low with high oil cuts. The oil produced to the surface averaged $14.9 \mathrm{bpd}$ and the water produced to the surface averaged $7.3 \mathrm{bpd}$. The oil cut was $67 \%$. However, after January 25 , no more oil was produced during this period. The water produced to the surface ranged from 2 to $3 \mathrm{bpd}$.

\section{Dows Unit Down from February 17 to March 9, 1999}

The DOWS unit failed on February 17, 1999, and was pulled from the well the same day. At that time it was discovered that the tubing below the DOWS assembly was corroded and perforated. A new DOWS unit was installed on March 9 and began operations on March 11.

\section{Operations Data from March 11 to March 22, 1999}

The new DOWS unit functioned stably from March 11 to March 22, 1999. Injection pressures and rates were moderate, while volume of oil and water produced was at low. On March 15, injection was stepped up. Although the injection rate was raised, there was no influence on fluid production.

Injection pressures gradually declined from about 1,600 psi on March 11 to about 1,560 psi on March 15. During most of this period, pressures varied back and forth between a gradually declining pressure and an alternate pressure drop of about 40 psi (Figure 11). The plot of pressure against time shows a bimodal distribution, with the majority of the points scattered along the 1,600 to 1,560 psi trend, and the rest plotting about 40 psi less. Very few points were outside that bimodal pattern. After pump speed was increased, pressures increased to approximately 1,620 psi and continued at about that value until the end of the period. Pressure was not consistent, varying from 1,600 to 1,650 psi; minor fluctuations in injection pressure were not reflected in the injection rate, which remained on a consistent trend. In addition, pressures continued to switch between trends approximately $40 \mathrm{psi}$ apart, even after pump speed was increased. The 40-psi variance between pressure readings is most likely an artifact of the functioning of downhole sensors.

The injection rate remained fairly constant at approximately 2,720 bpd from March 11 to March 15. On March 15, the increase in injection pressure raised injection rates to about $3,000 \mathrm{bpd}$. The injection rate continued to climb during the period to about $3,020 \mathrm{bpd}$.

As shown in Figure 12, injectivity increased from about 1.7 to $1.9 \mathrm{bpd} / \mathrm{psi}$ during the period. This magnitude of injectivity is only half the pre-DOWS rate, half of the calculated injectivity from December 1 to January 8 (see above), and one-third the apparent injectivity rate measured in that period.

The borehole pressure sensor did not function after the reinstallation.

\section{Operating Data from March 23 to December 10, 1999}

Detailed Promore downhole data were not saved for the period March 23 to December 10 , 1999 , nor was the borehole pressure sensor working. Injection and production parameters were stable during the period, and water production to the surface was consistent, although oil production was low.

Injection pressure (Figure 13) gradually declined from a starting value of about 1,600 psi to 
$1,400 \mathrm{psi}$. The injection rate gradually varied from a starting value of about $3,150 \mathrm{bpd}$ to about $3,400 \mathrm{bpd}$ at the end of the period. Injectivity (Figure 14) rose gradually from about $2.0 \mathrm{bpd} / \mathrm{psi}$ to about $2.4 \mathrm{bpd} / \mathrm{psi}$. These injectivity values represent a significant drop from the calculated injectivity values of 3.3 to $4.1 \mathrm{bpd} / \mathrm{psi}$ between December 1,1998 , and January 8,1999 , as well as from the pre-DOWS values of 3.4 to $4.8 \mathrm{bpd} / \mathrm{psi}$. The decrease could be due to plugging of the injection zone as was noted in the initial DOWS run.

Surface water production during this period varied from approximately 250 to $350 \mathrm{bpd}$. Oil production was erratic, typically varying from approximately 3 to more than 20 bpd (Figure 15). Total oil cuts were quite erratic, varying from $0.1 \%$ to $0.8 \%$. The decrease in oil production and in oil cut from pre-DOWS operation ( $43 \mathrm{bpd}$ of oil, $1.25 \%$ ) and the initial DOWS run (43.4 bpd of oil, $1.68 \%$ ) is significant.

\section{Tracer Survey September 8-12, 1999}

A tracer survey was conducted on the well September 8-12,1999, in an attempt to document recycling of injectate behind the casing into the production zone. The survey results are shown graphically in Figure 16.

The tracer survey followed a spike of lithium-charged water added to the borehole. This survey was conducted at a time when the well was averaging $3,304 \mathrm{bpd}$ total production - $252 \mathrm{bpd}$ to the surface and 3,052 bpd injected. During the time represented in Figure 16, the well averaged $6.2 \%$ oil in the produced fluid, but this rate varied in detail during the survey from nearly $0 \%$ to almost $100 \%$.

Only trace amounts of lithium were seen until 60 minutes after injection of the lithium solution. (Sixty minutes was the time required for the lithium to travel down the annulus, through the DOWS system, and up the tubing to the surface). The spike that began at 60 minutes was the dominant feature in lithium recovery, although the lithium continued to appear even in the last sample taken at 6,100 minutes. Of the total $16.715 \mathrm{~kg}$ of lithium placed in the well, $15.44 \mathrm{~kg}$ was injected underground, and approximately $1.27 \mathrm{~kg}(7.6 \%)$ should have been brought to the surface along with the produced fluids. However, $8.14 \mathrm{~kg}(48.7 \%)$ was actually recovered. These numbers strongly suggest that significant recycling of injectate was occurring, beginning with the 90-minute sample. In fact, the data indicate that $6.87 \mathrm{~kg}$ of lithium brought to the surface was from recycled injectate. This means that $44.5 \%$ of the injected lithium was eventually recycled and produced to the surface. Most of this recycling happened 30 minutes after the initial lithium spike came to the surface. These findings can be interpreted as meaning that nearly $50 \%$ of the injectate was being recycled during the operational history of this DOWS well. A further extrapolation is that the oil/water mixture brought to the surface was approximately $50 \%$ recycled fluid, and the oil was being diluted by previously extracted fluid.

Total oil cut (the percent of oil in the total volume of produced fluids) varied during the entire DOWS test from October 29, 1998, to December 10, 1999 (Figure 17). Total oil cut can be a measure of the reservoir's performance. Surface oil cut, defined as the percentage of the fluid produced to the surface that is oil, also is shown in Figure 17. Surface oil cut is a measure of the separation efficiency of the DOWS assembly. During the lithium survey, the well averaged $0.48 \%$ total oil cut, but this figure actually represents $50 \%$ reservoir fluids and $50 \%$ recycled fluid. The virgin reservoir fluid, therefore, had a total oil cut of approximately $0.96 \%$ compared to the pre-DOWS level of $1.25 \%$ and the initial DOWS test rate of $1.68 \%$. Most of the time during the second DOWS test (from March 11 to December 10), the total oil cut was approximately 
$0.20 \%$; assuming a $50 \%$ dilution factor, these values are significantly below the pre-DOWS levels. The decrease from $1.25 \%$ total oil at pre-DOWS to approximately $0.40 \%$ during an extended DOWS test suggests that recycling of injectate may actually have been more extensive than indicated during the tracer survey.

\section{Production Summary}

The volumes of oil and water produced to the surface during DOWS operation are listed in Table 5. Except for the first 18 days after start-up, oil production was well below baseline (before installation of the DOWS). Total fluid withdrawal from the producing zone remained approximately the same throughout the test as during pre-installation conditions. The first 18 days of DOWS operation was much like forecast for production with a DOWS in place - drastic reduction in water production while maintaining oil production, indeed oil cut actually increased. 



\section{Chapter 6 - Conclusions}

The examination of the details regarding the installation, testing, and operation of the DOWS unit, as well as the associated problems, lead to a number of conclusions regarding the specific operation and the DOWS technology in general. Some of the more relevant conclusions are itemized below:

1. The DOWS system was not an economic success, except for a short period at the start of the field trial.

2. Less oil was brought to the surface during the DOWS test than before the test when the well was equipped with a conventional electric submersible pump. The most serious problem was the corroding of the tubing below the hydrocyclone that allowed injectate to recycle into the annulus. The corrosion problem might have been due to mechanical or electrical problems at the well and may have been unavoidable, but the presence of this problem could have been seen almost immediately on the downhole sensor data. In addition, the lack of significant volumes of oil and water at the surface could have been a warning of irregular DOWS performance.

3. Very early in the field trial, downhole sensors in the well showed breakthrough between the injection and the production zones. Although minor when it began, by the time of the tracer survey, communication was approximately $50 \%$ of the injected volume. Communication appeared to be happening intermittently, demonstrating that bypass is not always a catastrophic failure of the confining zone. Failure of the confining zone may be due to fracturing or may be less sudden. Without the help of reliable downhole data, however, it may be impossible to detect fracturing or partial bypass. The problem could probably have been avoided by using lower injection pressures below the fracture pressure of approximately $1,800 \mathrm{psi}$.

4. Downhole instrumentation is vital for interpreting the results of a DOWS installation. Without the detailed information supplied by the Promore ${ }^{T M}$ pressure instruments, the surface production data would have been meaningless. The pressure and flow data from the subject well were reliable, repeatable, and comparable to pre-DOWS test data.

5. Lack of produced fluid to the surface can be caused by many problems that may be difficult to diagnose without downhole instrumentation. In the case of the subject well, the cessation of fluid was caused by corrosion through the tubing resulting in lack of pressure from the pump.

6. Injection zone plugging-off from formation fines is a significant problem, especially with clastic reservoirs. Downhole data will identify plugging and alert the operator to upcoming problems. The subject field trial demonstrated that well treatments can be accomplished while the DOWS unit is in place. However, the acidization job also highlighted some of the problems that can occur downhole.

7. Durability of the DOWS tools is highly variable, depending on many factors. In the case of the subject well, operation of the well created a significant amount of formation fines, but the hydrocyclone was not harmed after 16 months of use. 


\section{Acknowledgments}

Argonne's work was sponsored by the U.S. Department of Energy, Office of Fossil Energy, National Petroleum Technology Office (NPTO), under Contract W-31-109-Eng-38. Nancy Comstock served as the NPTO's contract officer. Argonne also wishes to acknowledge the cooperation and support of the operator who supplied the data for this study. Argonne's John DePue provided valuable editing of the report.

\section{References}

Galloway, W.E., et al., 1983, Atlas of Major Oil and Gas Reservoirs, Texas Bureau of Economic Geology, Austin, Texas.

Veil, J.A., B.G. Langhus, and S. Belieu, 1999, Feasibility Evaluation of Downhole OillWater Separation (DOWS) Technology, prepared for U.S. Department of Energy, Office of Fossil Energy, National Petroleum Technology Office, by Argonne National Laboratory, CH2M-Hill, and Nebraska Oil and Gas Conservation Commission, January. 

Table 1: Daily Production and Operations Data

\begin{tabular}{|c|c|c|c|c|c|c|c|c|c|c|}
\hline Date & Time & $\begin{array}{l}\text { Oil } \\
\text { Production } \\
\text { (bpd) }\end{array}$ & $\begin{array}{c}\text { Water } \\
\text { Production } \\
\text { (bpd) }\end{array}$ & $\begin{array}{l}\text { Total Fluid } \\
\text { Production } \\
\text { (bpd) }\end{array}$ & $\begin{array}{c}\text { Surface } \\
\text { oil cut } \\
(\%)\end{array}$ & $\begin{array}{c}\text { Total } \\
\text { Oil Cut } \\
(\%)\end{array}$ & $\begin{array}{c}\text { Injection } \\
\text { Pressure } \\
\text { (psi) }\end{array}$ & $\begin{array}{c}\text { Injection } \\
\text { Rate } \\
\text { (bpd) }\end{array}$ & $\begin{array}{c}\text { Injectivity } \\
\text { (bbl/psi) }\end{array}$ & $\begin{array}{c}\text { Annulus } \\
\text { Pressure (psi) } \\
\end{array}$ \\
\hline $10 / 29 / 1998$ & 1:45 PM & 0 & 0 & 0 & 0.0 & 0.0 & 1,180 & 3,780 & 3.2 & 818 \\
\hline $10 / 30 / 1998$ & $6: 30 \mathrm{AM}$ & 66 & 361 & 427 & 15.5 & 2.0 & 1,646 & 2,838 & 1.7 & 822 \\
\hline $10 / 31 / 1998$ & 8:00 AM & 61 & 463 & 524 & 11.6 & 2.2 & 1,860 & 2,310 & 1.2 & 822 \\
\hline $11 / 1 / 1998$ & 6:30 AM & 52 & 574 & 626 & 8.3 & 2.0 & 1,992 & 2,002 & 1.0 & 823 \\
\hline $11 / 2 / 1998$ & 6:30 AM & 44 & 627 & 671 & 6.6 & 1.8 & 2,104 & 1,730 & 0.8 & 825 \\
\hline $11 / 3 / 1998$ & 6:30 AM & 50 & 600 & 650 & 7.7 & 2.1 & 2,121 & 1,691 & 0.8 & 825 \\
\hline $11 / 4 / 1998$ & $6: 30$ AM & 40 & 579 & 619 & 6.5 & 1.7 & 2,300 & 1,679 & 0.7 & 825 \\
\hline $11 / 5 / 1998$ & $6: 30$ AM & 39 & 607 & 646 & 6.0 & 1.9 & 2,390 & 1,456 & 0.6 & 826 \\
\hline 11/6/1998 & $6: 30 \mathrm{AM}$ & 26 & 381 & 407 & 6.4 & 1.2 & 2,314 & 1,846 & 0.8 & 829 \\
\hline $11 / 7 / 1998$ & $6: 30 \mathrm{AM}$ & 41 & 402 & 443 & 9.3 & 2.1 & 2,548 & 1,479 & 0.6 & 831 \\
\hline $11 / 8 / 1998$ & $6: 30 \mathrm{AM}$ & 29 & 273 & 302 & 9.6 & 9.6 & 908 & & 0.0 & 829 \\
\hline $11 / 9 / 1998$ & $6: 30 \mathrm{AM}$ & & & & 0.0 & 0.0 & 909 & & 0.0 & 829 \\
\hline $11 / 10 / 1998$ & $6: 30 \mathrm{AM}$ & 32 & 362 & 394 & 8.1 & 1.7 & 2,478 & 1,494 & 0.6 & 830 \\
\hline $11 / 11 / 1998$ & $3: 15 \mathrm{AM}$ & 40 & 443 & 483 & 8.3 & 8.3 & & & 0.0 & \\
\hline $11 / 12 / 1998$ & Field Shutdown & & & & 0.0 & 0.0 & & & 0.0 & \\
\hline $11 / 13 / 1998$ & $6: 30 \mathrm{AM}$ & 38 & 521 & 559 & 6.8 & 2.0 & 2,491 & 1,381 & 0.6 & 833 \\
\hline $11 / 14 / 1998$ & $6: 45$ AM & 48 & 514 & 562 & 8.5 & 2.5 & 2,534 & 1,394 & 0.6 & 833 \\
\hline $11 / 15 / 1998$ & $6: 45 \mathrm{AM}$ & 41 & 520 & 561 & 7.3 & 2.2 & 2,545 & 1,334 & 0.5 & 833 \\
\hline $11 / 16 / 1998$ & Shutdown Due To High Amps & & & & 0.0 & 0.0 & & & 0.0 & \\
\hline $11 / 17 / 1998$ & Shutdown Due To High Amps & & & & 0.0 & 0.0 & & & 0.0 & \\
\hline 11/18/1998 & Shutdown Due To High Amps & & & & 0.0 & 0.0 & & & 0.0 & \\
\hline $11 / 19 / 1998$ & $6: 45$ AM & & & & 0.0 & 0.0 & 879 & 4,572 & 5.2 & 827 \\
\hline $11 / 20 / 1998$ & $6: 45 \mathrm{AM}$ & & & & 0.0 & 0.0 & 880 & 4,741 & 5.4 & 828 \\
\hline
\end{tabular}


Table 1: Daily Production and Operations Data

\begin{tabular}{|c|c|c|c|c|c|c|c|c|c|c|}
\hline Date & Time & $\begin{array}{c}\text { Oil } \\
\text { Production } \\
\text { (bpd) }\end{array}$ & $\begin{array}{c}\text { Water } \\
\text { Production } \\
\text { (bpd) }\end{array}$ & $\begin{array}{c}\text { Total Fluid } \\
\text { Production } \\
\text { (bpd) }\end{array}$ & \begin{tabular}{|c|}
$\begin{array}{c}\text { Surface } \\
\text { oil cut } \\
(\%)\end{array}$ \\
\end{tabular} & $\begin{array}{c}\text { Total } \\
\text { Oil Cut } \\
(\%) \\
\end{array}$ & $\begin{array}{c}\text { Injection } \\
\text { Pressure } \\
\text { (psi) }\end{array}$ & $\begin{array}{c}\text { Injection } \\
\text { Rate } \\
\text { (bpd) } \\
\end{array}$ & $\begin{array}{l}\text { Injectivity } \\
\text { (bbl/psi) }\end{array}$ & $\begin{array}{c}\text { Annulus } \\
\text { Pressure (psi) }\end{array}$ \\
\hline $11 / 21 / 1998$ & $6: 45 \mathrm{AM}$ & & & & 0.0 & 0.0 & 880 & 4,690 & 5.3 & 829 \\
\hline $11 / 22 / 1998$ & $6: 45 \mathrm{AM}$ & & & & 0.0 & 0.0 & 888 & 4,571 & 5.1 & 829 \\
\hline $11 / 23 / 1998$ & $6: 45 \mathrm{AM}$ & & & & 0.0 & 0.0 & 887 & 4,510 & 5.1 & 829 \\
\hline $11 / 24 / 1998$ & $6: 45$ AM & & & & 0.0 & 0.0 & 891 & 4,532 & 5.1 & 829 \\
\hline $11 / 25 / 1998$ & $6: 45$ AM & & & & 0.0 & 0.0 & 897 & 4,486 & 5.0 & 828 \\
\hline $11 / 26 / 1998$ & $6: 45$ AM & & & & 0.0 & 0.0 & 899 & 4,571 & 5.1 & 828 \\
\hline $11 / 27 / 1998$ & $6: 45$ AM & & & & 0.0 & 0.0 & 908 & 4,571 & 5.0 & 827 \\
\hline $11 / 28 / 1998$ & $6: 45$ AM & & & & 0.0 & 0.0 & 893 & 4,615 & 5.2 & 829 \\
\hline $11 / 29 / 1998$ & $6: 45$ AM & 9 & 17 & 26 & 34.6 & 0.2 & 880 & 4,708 & 5.4 & 826 \\
\hline $11 / 30 / 1998$ & $6: 45 \mathrm{AM}$ & 19 & 16 & 35 & 54.3 & 0.4 & 881 & 4,678 & 5.3 & 822 \\
\hline $12 / 1 / 1998$ & $6: 45 \mathrm{AM}$ & 21 & 5 & 26 & 80.8 & 0.4 & 833 & 4,662 & 5.6 & 822 \\
\hline $12 / 2 / 1998$ & 6:45 AM & 16 & 0 & 16 & 100.0 & 0.4 & 886 & 4,552 & 5.1 & 820 \\
\hline $12 / 3 / 1998$ & $6: 45 \mathrm{AM}$ & 17 & 3 & 20 & 85.0 & 0.4 & 883 & 4,661 & 5.3 & 827 \\
\hline $12 / 4 / 1998$ & $6: 45$ AM & 16 & 3 & 19 & 84.2 & 0.3 & 882 & 4,590 & 5.2 & 827 \\
\hline $12 / 5 / 1998$ & $6: 45$ AM & 31 & 3 & 34 & 91.2 & 0.7 & 894 & 4,514 & 5.0 & 820 \\
\hline $12 / 6 / 1998$ & $6: 45 \mathrm{AM}$ & 21 & 7 & 28 & 75.0 & 0.5 & 890 & 4,518 & 5.1 & 826 \\
\hline $12 / 7 / 1998$ & $6: 45$ AM & 15 & 3 & 18 & 83.3 & 0.3 & 888 & 4,532 & 5.1 & 822 \\
\hline $12 / 8 / 1998$ & $6: 45 \mathrm{AM}$ & 18 & 3 & 21 & 85.7 & 0.4 & 884 & 4,591 & 5.2 & 823 \\
\hline $12 / 9 / 1998$ & $6: 45 \mathrm{AM}$ & 23 & 2 & 25 & 92.0 & 0.5 & 876 & 4,592 & 5.2 & 823 \\
\hline $12 / 10 / 1998$ & $6: 45 \mathrm{AM}$ & 0 & 0 & 0 & 0.0 & 0.0 & 876 & 4,613 & 5.3 & 821 \\
\hline $12 / 11 / 1998$ & $6: 45 \mathrm{AM}$ & 24 & 2 & 26 & 92.3 & 0.5 & 877 & 4,582 & 5.2 & 824 \\
\hline $12 / 12 / 1998$ & $6: 45 \mathrm{AM}$ & 0 & 0 & 0 & 0.0 & 0.0 & 880 & 4,593 & 5.2 & 824 \\
\hline $12 / 13 / 1998$ & $6: 45 \mathrm{AM}$ & 24 & 4 & 28. & 85.7 & 0.5 & 877 & 4,599 & 5.2 & 824 \\
\hline $12 / 14 / 1998$ & $6: 45 \mathrm{AM}$ & 이 & 0 & 0 & 0.0 & 0.0 & 877 & 4,517 & 5.2 & 822 \\
\hline
\end{tabular}


Table 1: Daily Production and Operations Data

\begin{tabular}{|c|c|c|c|c|c|c|c|c|c|c|}
\hline Date & Time & $\begin{array}{c}\text { Oil } \\
\text { Production } \\
\text { (bpd) }\end{array}$ & $\begin{array}{c}\text { Water } \\
\text { Production } \\
\text { (bpd) }\end{array}$ & $\begin{array}{c}\text { Total Fluid } \\
\text { Production } \\
\text { (bpd) }\end{array}$ & \begin{tabular}{|c|}
$\begin{array}{c}\text { Surface } \\
\text { oil cut } \\
(\%)\end{array}$ \\
\end{tabular} & \begin{tabular}{|c|} 
Total \\
Oil Cut \\
$(\%)$ \\
\end{tabular} & $\begin{array}{c}\text { Injection } \\
\text { Pressure } \\
\text { (psi) } \\
\end{array}$ & \begin{tabular}{|c|}
$\begin{array}{c}\text { Injection } \\
\text { Rate } \\
\text { (bpd) }\end{array}$ \\
\end{tabular} & $\begin{array}{c}\text { Injectivity } \\
\text { (bbl/psi) }\end{array}$ & $\begin{array}{c}\text { Annulus } \\
\text { Pressure (psi) }\end{array}$ \\
\hline $12 / 15 / 1998$ & $6: 45 \mathrm{AM}$ & 24 & 2 & 26 & \begin{tabular}{|r|}
92.3 \\
\end{tabular} & 0.5 & 876 & 4,609 & 5.3 & 824 \\
\hline $12 / 16 / 1998$ & $6: 45 \mathrm{AM}$ & 26 & 3 & 29 & 89.7 & 0.6 & 877 & 4,564 & 5.2 & 823 \\
\hline $12 / 17 / 1998$ & $6: 45 \mathrm{AM}$ & & & & 0.0 & 0.0 & 881 & 4,593 & 5.2 & 823 \\
\hline $12 / 18 / 1998$ & $6: 45 \mathrm{AM}$ & 22 & 2 & 24 & 91.7 & 0.5 & 881 & 4,597 & 5.2 & 823 \\
\hline $12 / 19 / 1998$ & 6:45 AM & 25 & 3 & 28 & 89.3 & 0.5 & 879 & 4,558 & 5.2 & 823 \\
\hline $12 / 20 / 1998$ & $6: 45 \mathrm{AM}$ & 0 & 0 & 0 & 0.0 & 0.0 & 879 & 4,610 & 5.2 & 823 \\
\hline $12 / 21 / 1998$ & $6: 45 \mathrm{AM}$ & 25 & 2 & 27 & 92.6 & 0.5 & 880 & 4,553 & 5.2 & 823 \\
\hline $12 / 22 / 1998$ & $6: 45 \mathrm{AM}$ & & & & 0.0 & 0.0 & & & 0.0 & 0 \\
\hline $12 / 23 / 1998$ & $6: 45 \mathrm{AM}$ & & & & 0.0 & 0.0 & 869 & 4,644 & 5.3 & 824 \\
\hline $12 / 24 / 1998$ & $6: 45 \mathrm{AM}$ & 11 & 0 & 11 & 100.0 & 0.2 & 878 & 4,624 & 5.3 & 823 \\
\hline $12 / 25 / 1998$ & $6: 45 \mathrm{AM}$ & 23 & 2 & 25 & 92.0 & 0.5 & 871 & 4,778 & 5.5 & 822 \\
\hline $12 / 26 / 1998$ & $6: 45 \mathrm{AM}$ & 0 & $\underline{0}$ & 0 & 0.0 & 0.0 & 883 & 4,496 & 5.1 & 829 \\
\hline $12 / 27 / 1998$ & $6: 45 \mathrm{AM}$ & 25 & 2 & 27 & 92.6 & 0.5 & 877 & 4,600 & 5.2 & 823 \\
\hline $12 / 28 / 1998$ & 6:45 AM & 24 & 3 & 27 & 88.9 & 0.5 & 879 & 4,566 & 5.2 & 824 \\
\hline $12 / 29 / 1998$ & $6: 45 \mathrm{AM}$ & & & & 0.0 & 0.0 & 883 & 4,558 & 5.2 & 822 \\
\hline $12 / 30 / 1998$ & $6: 45 \mathrm{AM}$ & 25 & 2 & 27 & 92.6 & 0.5 & 885 & 4,539 & 5.1 & 822 \\
\hline $12 / 31 / 1998$ & $6: 45 \mathrm{AM}$ & & & & 0.0 & 0.0 & 882 & 4,473 & 5.1 & 822 \\
\hline $1 / 1 / 1999$ & $6: 45 \mathrm{AM}$ & 25 & 3 & 28 & 89.3 & 0.5 & 881 & 4,528 & 5.1 & 824 \\
\hline $1 / 2 / 1999$ & $6: 45 \mathrm{AM}$ & 26 & 2 & 28 & 92.9 & 0.6 & 877 & 4,537 & 5.2 & 822 \\
\hline $1 / 3 / 1999$ & $6: 45 \mathrm{AM}$ & 1 & & 1 & 100.0 & 0.0 & 921 & & 0.0 & 833 \\
\hline $1 / 4 / 1999$ & $6: 45 \mathrm{AM}$ & & & & 0.0 & 0.0 & 920 & & 0.0 & 832 \\
\hline 1/5/1999 & $6: 45 \mathrm{AM}$ & & & & 0.0 & 0.0 & 921 & & 0.0 & 833 \\
\hline $1 / 6 / 1999$ & 6:45 AM & & & & 0.0 & 0.0 & 878 & 4,425 & 5.0 & 829 \\
\hline $1 / 7 / 1999$ & $6: 45 \mathrm{AM}$ & 14 & 2 & 16 & 0.0 & 0.3 & 878 & 4,490 & 5.1) & 829 \\
\hline
\end{tabular}




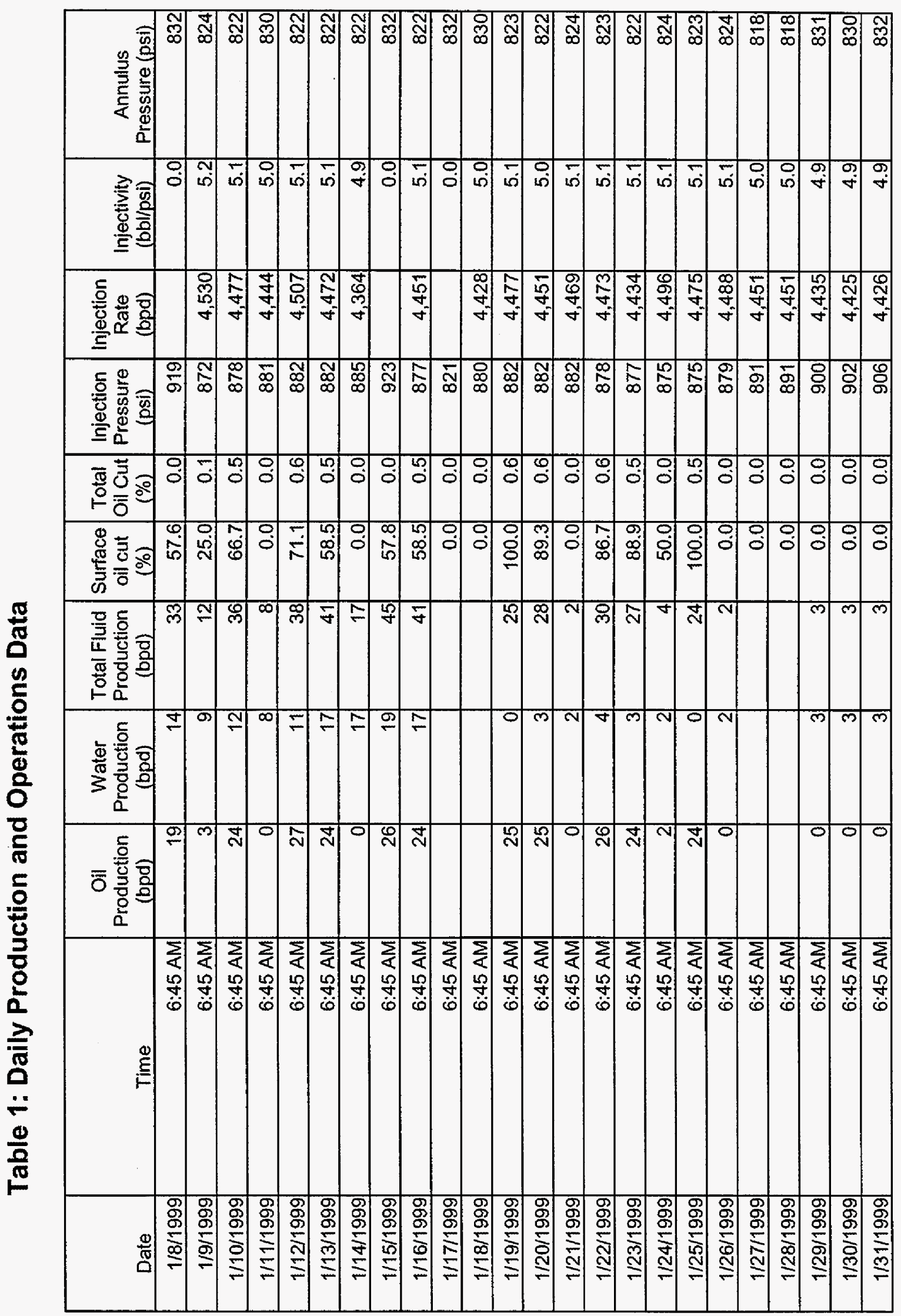


Table 1: Daily Production and Operations Data

\begin{tabular}{|c|c|c|c|c|c|c|c|c|c|c|}
\hline Date & Time & $\begin{array}{c}\text { Oil } \\
\text { Production } \\
\text { (bpd) }\end{array}$ & $\begin{array}{c}\begin{array}{c}\text { Water } \\
\text { Production } \\
\text { (bpd) }\end{array} \\
\end{array}$ & $\begin{array}{l}\text { Total Fluid } \\
\text { Production } \\
\text { (bpd) }\end{array}$ & $\begin{array}{c}\text { Surface } \\
\text { oil cut } \\
(\%)\end{array}$ & $\begin{array}{c}\text { Total } \\
\text { Oil Cut } \\
(\%) \\
\end{array}$ & $\begin{array}{l}\text { Injection } \\
\text { Pressure } \\
\text { (psi) }\end{array}$ & $\begin{array}{c}\text { Injection } \\
\text { Rate } \\
\text { (bpd) } \\
\end{array}$ & $\begin{array}{c}\text { Injectivity } \\
\text { (bbl/psi) }\end{array}$ & $\begin{array}{c}\text { Annulus } \\
\text { Pressure (psi) }\end{array}$ \\
\hline $2 / 1 / 1999$ & $6: 45 \mathrm{AM}$ & 0 & 3 & 3 & $\quad 0.0$ & 0.0 & $\begin{array}{r}910 \\
\end{array}$ & $\begin{array}{r}4,432 \\
\end{array}$ & 4.9 & 832 \\
\hline 2/2/1999 & $6: 45 \mathrm{AM}$ & 0 & 4. & 4 & 0.0 & 0.0 & 913 & 4,465 & 4.9 & 833 \\
\hline 2/3/1999 & $6: 45 \mathrm{AM}$ & 0 & 5 & 5 & 0.0 & 0.0 & 918 & 4,450 & 4.8 & 833 \\
\hline $2 / 4 / 1999$ & $6: 45 \mathrm{AM}$ & 0 & 6 & 6 & 0.0 & 0.0 & 922 & 4,440 & 4.8 & 833 \\
\hline 2/5/1999 & 6:45 AM & 0 & 3 & 3 & 0.0 & 0.0 & 930 & 4,424 & 4.8 & 833 \\
\hline $2 / 6 / 1999$ & 6:45 AM & 0 & 4 & 4 & 0.0 & 0.0 & 938 & 4,396 & 4.7 & 833 \\
\hline 2/7/1999 & $6: 45 \mathrm{AM}$ & 0 & 8 & 8 & 0.0 & 0.0 & 944 & 4,372 & 4.6 & 833 \\
\hline 2/8/1999 & $6: 45 \mathrm{AM}$ & 0 & 9 & 9 & 0.0 & 0.0 & 953 & 4,328 & 4.5 & 833 \\
\hline $2 / 9 / 1999$ & $6: 45 \mathrm{AM}$ & 0 & 10 & 10 & 0.0 & 0.0 & 988 & 4,222 & 4.3 & 833 \\
\hline $2 / 10 / 1999$ & $6: 45 \mathrm{AM}$ & 0 & 13 & 13 & 0.0 & 0.0 & 990 & 4,385 & 4.4 & 833 \\
\hline $2 / 11 / 1999$ & $6: 45 \mathrm{AM}$ & 0 & 13 & 13 & 0.0 & 0.0 & 966 & 4,622 & 4.8 & 834 \\
\hline $2 / 12 / 1999$ & 6:45 AM & 0 & 10 & 10 & 0.0 & 0.0 & 979 & 4,678 & 4.8 & 849 \\
\hline 2/13/1999 & $6: 45 \mathrm{AM}$ & 0 & 6 & 6 & 0.0 & 0.0 & 972 & 4,681 & 4.8 & 842 \\
\hline $2 / 14 / 1999$ & $6: 45 \mathrm{AM}$ & 0 & 5 & 5 & 0.0 & 0.0 & 980 & 4,530 & 4.6 & 856 \\
\hline $2 / 15 / 1999$ & $6: 45 \mathrm{AM}$ & 0 & 5 & 5 & 0.0 & 0.0 & 1,038 & 4,846 & 4.7 & 860 \\
\hline 2/16/1999 & 6:45 AM & 0 & 6 & 6 & 0.0 & 0.0 & 1,102 & 4,951 & 4.5 & 864 \\
\hline $2 / 17 / 1999$ & 12:00 AM & & & & 0.0 & 0.0 & & & 0.0 & \\
\hline $2 / 18 / 1999$ & $12: 00 \mathrm{AM}$ & & & & 0.0 & 0.0 & & & 0.0 & \\
\hline $2 / 19 / 1999$ & $12: 00 \mathrm{AM}$ & & & & 0.0 & 0.0 & & & 0.0 & \\
\hline $2 / 20 / 1999$ & $12: 00 \mathrm{AM}$ & & & & 0.0 & 0.0 & & & 0.0 & \\
\hline $2 / 21 / 1999$ & $12: 00 \mathrm{AM}$ & & & & 0.0 & 0.0 & & & 0.0 & \\
\hline 2/22/1999 & $12: 00 \mathrm{AM}$ & & & & 0.0 & 0.0 & & & 0.0 & \\
\hline $2 / 23 / 1999$ & $12: 00 \mathrm{AM}$ & & & & 0.0 & 0.0 & & & 0.0 & \\
\hline $2 / 24 / 1999$ & $12: 00 \mathrm{AM}$ & & & & 0.0 & 0.0 & & & 0.0 & \\
\hline
\end{tabular}




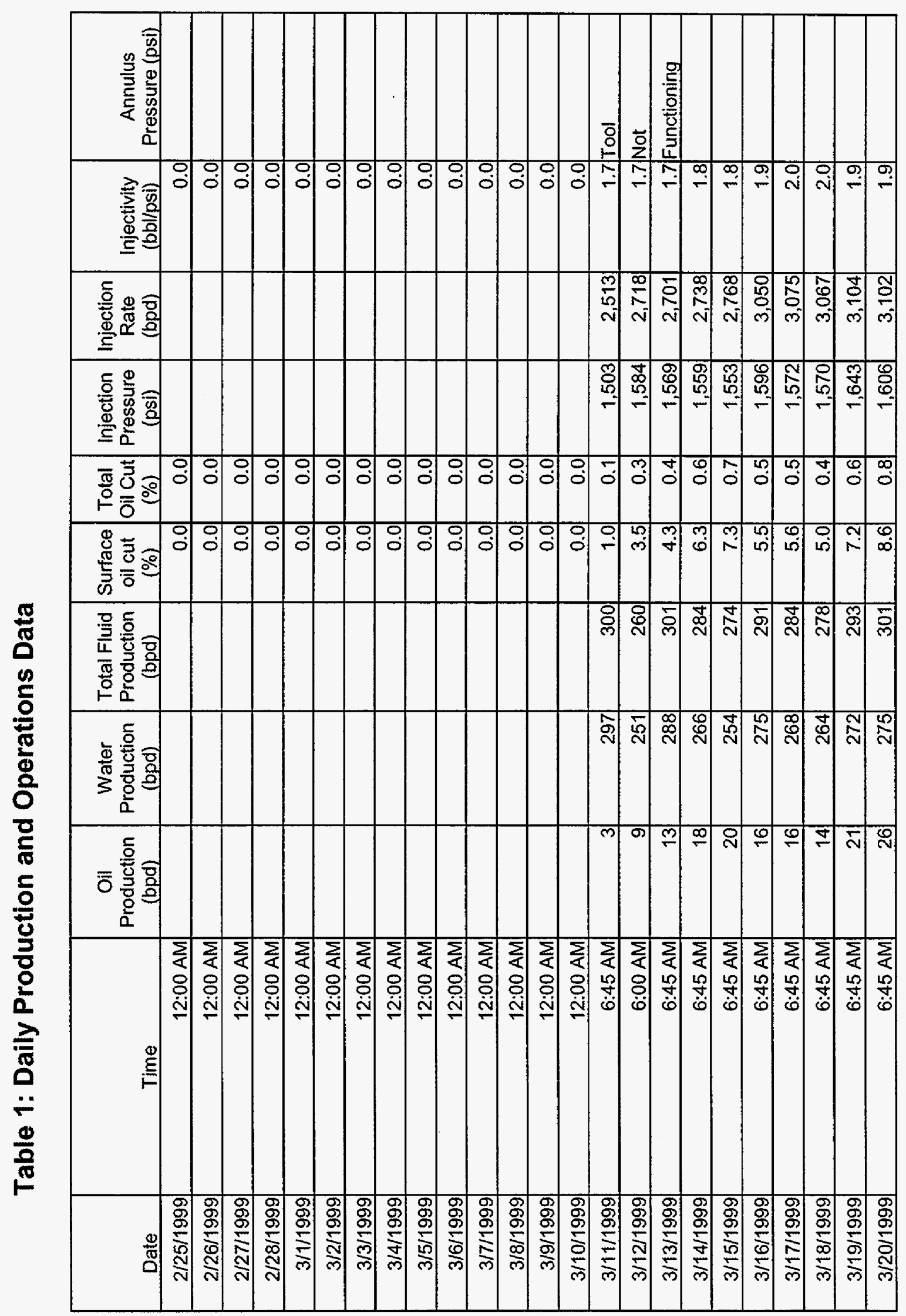


Table 1: Daily Production and Operations Data

\begin{tabular}{|c|c|c|c|c|c|c|c|c|c|c|}
\hline Date & Time & $\begin{array}{c}\text { Oil } \\
\begin{array}{c}\text { Production } \\
\text { (bpd) }\end{array} \\
\end{array}$ & $\begin{array}{c}\text { Water } \\
\text { Production } \\
\text { (bpd) }\end{array}$ & $\begin{array}{c}\text { Total Fluid } \\
\text { Production } \\
\text { (bpd) }\end{array}$ & $\begin{array}{c}\text { Surface } \\
\text { oil cut } \\
(\%)\end{array}$ & $\begin{array}{c}\text { Total } \\
\text { Oil Cut } \\
(\%) \\
\end{array}$ & $\begin{array}{c}\text { Injection } \\
\text { Pressure } \\
\text { (psi) }\end{array}$ & $\begin{array}{c}\text { Injection } \\
\text { Rate } \\
\text { (bpd) } \\
\end{array}$ & $\begin{array}{l}\text { Injectivity } \\
\text { (bbl/psi) }\end{array}$ & $\begin{array}{c}\text { Annulus } \\
\text { Pressure (psi) }\end{array}$ \\
\hline $3 / 21 / 1999$ & $6: 45 \mathrm{AM}$ & 24 & 267 & 291 & \begin{tabular}{|l}
8.2 \\
\end{tabular} & 0.7 & 1,590 & 3,195 & 2.0 & \\
\hline $3 / 22 / 1999$ & 6:45 AM & 11 & 265 & 276 & 4.0 & 0.3 & 1,619 & 3,092 & 1.9 & \\
\hline $3 / 23 / 1999$ & $6: 45 \mathrm{AM}$ & 9 & 273 & 282 & 3.2 & 0.3 & 1,623 & 3,089 & 1.9 & \\
\hline $3 / 24 / 1999$ & $6: 45 \mathrm{AM}$ & 4 & 280 & 284 & 1.4 & 0.1 & 1,592 & 3,024 & 1.9 & \\
\hline $3 / 25 / 1999$ & $6: 45 \mathrm{AM}$ & 5 & 281 & 286 & 1.7 & 0.1 & 1,605 & 3,131 & 2.0 & \\
\hline $3 / 26 / 1999$ & $6: 45 \mathrm{AM}$ & 12 & 284 & 296 & 4.1 & 0.4 & 1,602 & 3,114 & 1.9 & \\
\hline $3 / 27 / 1999$ & 6:45 AM & 14 & 288 & 302 & 4.6 & 0.4 & 1,598 & $\underline{3}, 139$ & 2.0 & \\
\hline $3 / 28 / 1999$ & $6: 45 \mathrm{AM}$ & 13 & 286 & 299 & 4.3 & 0.4 & 1,597 & 3,132 & 2.0 & \\
\hline $3 / 29 / 1999$ & $6: 45 \mathrm{AM}$ & 16 & 283 & 299 & 5.4 & 0.5 & 1,591 & 3,167 & 2.0 & \\
\hline $3 / 30 / 1999$ & 6:45 AM & 16 & 242 & 258 & 6.2 & 0.5 & 1,543 & 3,047 & 2.0 & \\
\hline $3 / 31 / 1999$ & $6: 45 \mathrm{AM}$ & 20 & 263 & 283 & 7.1 & 0.6 & 1,508 & 3,175 & 2.1 & \\
\hline $4 / 1 / 1999$ & 6:45 AM & 8 & 261 & 269 & 3.0 & 0.2 & 1,590 & 3,178 & 2.0 & \\
\hline $4 / 2 / 1999$ & 6:45 AM & 7 & 278 & 285 & 2.5 & 0.2 & 1,573 & 3,143 & 2.0 & \\
\hline $4 / 3 / 1999$ & 6:45 AM & 7 & 281 & 288 & 2.4 & 0.2 & 1,577 & 3,131 & 2.0 & \\
\hline 4/4/1999 & 6:45 AM & 8 & 280 & 288 & 2.8 & 0.2 & 1,573 & 3,163 & 2.0 & \\
\hline $4 / 5 / 1999$ & 6:45 AM & 9 & 279 & 288 & 3.1 & 0.3 & 1,566 & 3,161 & 2.0 & \\
\hline $4 / 6 / 1999$ & 6:45 AM & 6 & 250 & 256 & 2.3 & 0.2 & 1,566 & 3,149 & 2.0 & \\
\hline $4 / 7 / 1999$ & $6: 45 \mathrm{AM}$ & 8 & 283 & 291 & 2.7 & 0.2 & 1,566 & 3,151 & 2.0 & \\
\hline $4 / 8 / 1999$ & 6:45 AM & 7 & 280 & 287 & 2.4 & 0.2 & 1,533 & 3,082 & 2.0 & \\
\hline $4 / 9 / 1999$ & $6: 45 \mathrm{AM}$ & 9 & 291 & 300 & 3.0 & 0.3 & 1,548 & 3,128 & 2.0 & \\
\hline $4 / 10 / 1999$ & $6: 45 \mathrm{AM}$ & 16 & 232 & 248 & 6.5 & 0.5 & 1,540 & 3,087 & 2.0 & \\
\hline $4 / 11 / 1999$ & $6: 45 \mathrm{AM}$ & 3 & 256 & 259 & 1.2 & 0.1 & 1,527 & 3,205 & 2.1 & \\
\hline 4/12/1999 & 6:45 AM & 3 & 256 & 259 & 1.2 & 0.1 & 1,561 & 3,118 & 2.0 & \\
\hline $4 / 13 / 1999$ & $6: 45 \mathrm{AM}$ & 17 & 249 & 266 & 6.4 & 0.5 & 1,562 & 3,111 & 2.0 & \\
\hline
\end{tabular}


Table 1: Daily Production and Operations Data

\begin{tabular}{|c|c|c|c|c|c|c|c|c|c|c|}
\hline Date & Time & $\begin{array}{c}\text { Oil } \\
\text { Production } \\
\text { (bpd) }\end{array}$ & $\begin{array}{c}\text { Water } \\
\text { Production } \\
\text { (bpd) }\end{array}$ & $\begin{array}{c}\text { Total Fluid } \\
\text { Production } \\
\text { (bpd) }\end{array}$ & $\begin{array}{c}\text { Surface } \\
\text { oil cut } \\
(\%)\end{array}$ & $\begin{array}{c}\text { Total } \\
\text { Oil Cut } \\
(\%) \\
\end{array}$ & $\begin{array}{c}\text { Injection } \\
\text { Pressure } \\
\text { (psi) }\end{array}$ & $\begin{array}{c}\text { Injection } \\
\text { Rate } \\
\text { (bpd) }\end{array}$ & $\begin{array}{c}\text { Injectivity } \\
\text { (bbl/psi) }\end{array}$ & $\begin{array}{c}\text { Annulus } \\
\text { Pressure (psi) }\end{array}$ \\
\hline $4 / 14 / 1999$ & $6: 45 \mathrm{AM}$ & 16 & 268 & 284 & 5.6 & $\begin{array}{l}0.5 \\
\end{array}$ & 1,555 & 3,115 & 2.0 & \\
\hline $4 / 15 / 1999$ & $6: 45$ AM & 16 & 268 & 284 & 5.6 & 0.5 & 1,555 & 3,127 & 2.0 & \\
\hline $4 / 16 / 1999$ & $6: 45 \mathrm{AM}$ & 25 & 265 & 290 & 8.6 & 0.7 & 1,554 & 3,123 & 2.0 & \\
\hline $4 / 17 / 1999$ & $6: 45 \mathrm{AM}$ & 16 & 245 & 261 & 6.1 & 0.5 & 1,528 & 3,055 & 2.0 & \\
\hline $4 / 18 / 1999$ & $6: 45 \mathrm{AM}$ & 10 & 266 & 276 & 3.6 & 0.3 & 1,529 & 3,128 & 2.0 & \\
\hline $4 / 19 / 1999$ & $6: 45 \mathrm{AM}$ & 8 & 265 & 273 & 2.9 & 0.2 & 1,563 & 3,099 & 2.0 & \\
\hline $4 / 20 / 1999$ & $6: 45 \mathrm{AM}$ & 17 & 257 & 274 & 6.2 & 0.5 & 1,549 & 3,088 & 2.0 & \\
\hline $4 / 21 / 1999$ & $6: 45 \mathrm{AM}$ & 17 & 265 & 282 & 6.0 & 0.5 & 1,553 & 3,129 & 2.0 & \\
\hline $4 / 22 / 1999$ & $6: 45 \mathrm{AM}$ & 16 & 265 & 281 & 5.7 & 0.4 & 1,519 & 3,478 & 2.3 & \\
\hline $4 / 23 / 1999$ & $6: 45 \mathrm{AM}$ & 12 & 259 & 271 & 4.4 & 0.4 & 1,555 & 3,145 & 2.0 & \\
\hline 4/24/1999 & $6: 45 \mathrm{AM}$ & 12 & 259 & 271 & 4.4 & 0.4 & 1,557 & 3,135 & 2.0 & \\
\hline $4 / 25 / 1999$ & $6: 45 \mathrm{AM}$ & 15 & 256 & 271 & 5.5 & 0.4 & 1,538 & 3,074 & 2.0 & \\
\hline $4 / 26 / 1999$ & $6: 45 \mathrm{AM}$ & 11 & 265 & 276 & 4.0 & 0.3 & 1,565 & 3,120 & 2.0 & \\
\hline $4 / 27 / 1999$ & $6: 45 \mathrm{AM}$ & 11 & 265 & 276 & 4.0 & 0.3 & 1,564 & 3,103 & 2.0 & \\
\hline $4 / 28 / 1999$ & $6: 45 \mathrm{AM}$ & 21 & 259 & 280 & 7.5 & 0.6 & 1,524 & 3,145 & 2.1 & \\
\hline $4 / 29 / 1999$ & $6: 45 \mathrm{AM}$ & 21 & 259 & 280 & 7.5 & 0.6 & 1,557 & 3,119 & 2.0 & \\
\hline $4 / 30 / 1999$ & $6: 45 \mathrm{AM}$ & 18 & 256 & 274 & 6.6 & 0.5 & 1,554 & 3,020 & 1.9 & \\
\hline $5 / 1 / 1999$ & $6: 45 \mathrm{AM}$ & 21 & 259 & 280 & 7.5 & 0.6 & 1,558 & 3,143 & 2.0 & \\
\hline $5 / 2 / 1999$ & $6: 45 \mathrm{AM}$ & 12 & 269 & 281 & 4.3 & 0.4 & 1,564 & 3,085 & 2.0 & \\
\hline $5 / 3 / 1999$ & $6: 45 \mathrm{AM}$ & 12 & 256 & 268 & 4.5 & 0.4 & 1,528 & 3,088 & 2.0 & \\
\hline $5 / 4 / 1999$ & $6: 45 \mathrm{AM}$ & 12 & 269 & 281 & 4.3 & 0.4 & 1,565 & 3,100 & 2.0 & \\
\hline $5 / 5 / 1999$ & $6: 45 \mathrm{AM}$ & 18 & 259 & 277 & 6.5 & 0.5 & 1,536 & 3,048 & 2.0 & \\
\hline $5 / 6 / 1999$ & $6: 45 \mathrm{AM}$ & 8 & 268 & 276 & 2.9 & 0.2 & 1,553 & 3,094 & 2.0 & \\
\hline $5 / 7 / 1999$ & $6: 45 \mathrm{AM}$ & 8 & 268 & 276 & 2.9 & 0.2 & 1,551 & 3,119 & 2.0 & \\
\hline
\end{tabular}


Table 1: Daily Production and Operations Data

\begin{tabular}{|c|c|c|c|c|c|c|c|c|c|c|}
\hline Date & Time & $\begin{array}{c}\text { Oil } \\
\text { Production } \\
\text { (bpd) }\end{array}$ & $\begin{array}{c}\text { Water } \\
\text { Production } \\
\text { (bpd) }\end{array}$ & $\begin{array}{c}\text { Total Fluid } \\
\text { Production } \\
\text { (bpd) }\end{array}$ & $\begin{array}{c}\text { Surface } \\
\text { oil cut } \\
(\%)\end{array}$ & $\begin{array}{c}\text { Total } \\
\text { Oil Cut } \\
(\%) \\
\end{array}$ & $\begin{array}{c}\text { Injection } \\
\text { Pressure } \\
\text { (psi) }\end{array}$ & $\begin{array}{l}\text { Injection } \\
\text { Rate } \\
\text { (bpd) }\end{array}$ & $\begin{array}{c}\text { Injectivity } \\
\text { (bbl/psi) }\end{array}$ & $\begin{array}{c}\text { Annulus } \\
\text { Pressure (psi) }\end{array}$ \\
\hline $5 / 8 / 1999$ & $6: 45 \mathrm{AM}$ & 8 & 268 & 276 & $\begin{array}{r}2.9 \\
\end{array}$ & 0.2 & 1,553 & 3,108 & 2.0 & \\
\hline $5 / 9 / 1999$ & $6: 45 \mathrm{AM}$ & 22 & 266 & 288 & 7.6 & 0.6 & 1,547 & 3,198 & 2.1 & \\
\hline $5 / 10 / 1999$ & $6: 45 \mathrm{AM}$ & 22 & 266 & 288 & 7.6 & 0.6 & 1,564 & 3,147 & 2.0 & \\
\hline $5 / 11 / 1999$ & $6: 45 \mathrm{AM}$ & 12 & 266 & 278 & 4.3 & 0.4 & 1,550 & 3,101 & 2.0 & \\
\hline $5 / 12 / 1999$ & $6: 45 \mathrm{AM}$ & 12 & 266 & 278 & 4.3 & 0.4 & 1,554 & 3,109 & 2.0 & \\
\hline $5 / 13 / 1999$ & $6: 45 \mathrm{AM}$ & 15 & 259 & 274 & 5.5 & 0.4 & 1,549 & 3,108 & 2.0 & \\
\hline $5 / 14 / 1999$ & $6: 45 \mathrm{AM}$ & 15 & 259 & 274 & 5.5 & 0.4 & 1,554 & 3,126 & 2.0 & \\
\hline $5 / 15 / 1999$ & $6: 45 \mathrm{AM}$ & 16 & 253 & 269 & 5.9 & 0.5 & 1,551 & 3,151 & 2.0 & \\
\hline $5 / 16 / 1999$ & $6: 45 \mathrm{AM}$ & 12 & 255 & 267 & 4.5 & 0.4 & 1,557 & 3,096 & 2.0 & \\
\hline $5 / 17 / 1999$ & $6: 45 \mathrm{AM}$ & 14 & 259 & 273 & 5.1 & 0.4 & 1,548 & 3,127 & 2.0 & \\
\hline $5 / 18 / 1999$ & $6: 45 \mathrm{AM}$ & 18 & 263 & 281 & 6.4 & 0.5 & 1,548 & 3,127 & 2.0 & \\
\hline $5 / 19 / 1999$ & $6: 45 \mathrm{AM}$ & 12 & 257 & 269 & 4.5 & 0.4 & 1,492 & 2,991 & 2.0 & \\
\hline $5 / 20 / 1999$ & $6: 45 \mathrm{AM}$ & 13 & 240 & 253 & 5.1 & 0.4 & 1,544 & 3,070 & 2.0 & \\
\hline $5 / 21 / 1999$ & $6: 45 \mathrm{AM}$ & 14 & 251 & 265 & 5.3 & 0.4 & 1,497 & 2,986 & 2.0 & \\
\hline $5 / 22 / 1999$ & $6: 45$ AM & 18 & 234 & 252 & 7.1 & 0.6 & 1,587 & 2,959 & 1.9 & \\
\hline $5 / 23 / 1999$ & $6: 45 \mathrm{AM}$ & 16 & 249 & 265 & 6.0 & 0.5 & 1,535 & 3,098 & 2.0 & \\
\hline $5 / 24 / 1999$ & $6: 45 \mathrm{AM}$ & 14 & 252 & 266 & 5.3 & 0.4 & 1,566 & 3,242 & 2.1 & \\
\hline $5 / 25 / 1999$ & $6: 45 \mathrm{AM}$ & 12 & 259 & 271 & 4.4 & 0.4 & 1,536 & 3,093 & 2.0 & \\
\hline $5 / 26 / 1999$ & $6: 45 \mathrm{AM}$ & 15 & 252 & 267 & 5.6 & 0.4 & 1,483 & 3,121 & 2.1 & \\
\hline $5 / 27 / 1999$ & $6: 45 \mathrm{AM}$ & 17 & 249 & 266 & 6.4 & 0.5 & 1,504 & 3,104 & 2.1 & \\
\hline $5 / 28 / 1999$ & $6: 45$ AM & 16 & 253 & 269 & 5.9 & 0.5 & 1,509 & 3,046 & 2.0 & \\
\hline $5 / 29 / 1999$ & $6: 45 \mathrm{AM}$ & 13 & 228 & 241 & 5.4 & 0.4 & 1,545 & 3,099 & 2.0 & \\
\hline $5 / 30 / 1999$ & $6: 45 \mathrm{AM}$ & 10 & 231 & 241 & 4.1 & 0.3 & 1,511 & 3,029 & 2.0 & \\
\hline $5 / 31 / 1999$ & $6: 45 \mathrm{AM}$ & 12 & 247 & 259 & 4.6 & 0.4 & 1,556 & 3,146 & 2.0 & \\
\hline
\end{tabular}


Table 1: Daily Production and Operations Data

\begin{tabular}{|c|c|c|c|c|c|c|c|c|c|c|}
\hline Date & Time & $\begin{array}{c}\text { Oil } \\
\text { Production } \\
\text { (bpd) }\end{array}$ & $\begin{array}{c}\text { Water } \\
\text { Production } \\
\text { (bpd) }\end{array}$ & $\begin{array}{c}\text { Total Fluid } \\
\text { Production } \\
\text { (bpd) }\end{array}$ & $\begin{array}{c}\text { Surface } \\
\text { oil cut } \\
(\%)\end{array}$ & $\begin{array}{c}\text { Total } \\
\text { Oil Cut } \\
(\%) \\
\end{array}$ & $\begin{array}{c}\text { Injection } \\
\text { Pressure } \\
\text { (psi) }\end{array}$ & $\begin{array}{c}\text { Injection } \\
\text { Rate } \\
\text { (bpd) } \\
\end{array}$ & $\begin{array}{l}\text { Injectivity } \\
\text { (bbl/psi) }\end{array}$ & $\begin{array}{c}\text { Annulus } \\
\text { Pressure (psi) }\end{array}$ \\
\hline $6 / 1 / 1999$ & $6: 45 \mathrm{AM}$ & 11 & 264 & 275 & 4.0 & 0.3 & 1,564 & 3,166 & 2.0 & \\
\hline $6 / 2 / 1999$ & $6: 45$ AM & 10 & 255 & 265 & 3.8 & 0.3 & 1,550 & 3,300 & 2.1 & \\
\hline $6 / 3 / 1999$ & $6: 45$ AM & 9 & 248 & 257 & 3.5 & 0.2 & 1,524 & 3,449 & 2.3 & \\
\hline $6 / 4 / 1999$ & $6: 45 \mathrm{AM}$ & 8 & 243 & 251 & 3.2 & 0.2 & 1,556 & 3,097 & 2.0 & \\
\hline $6 / 5 / 1999$ & $6: 45 \mathrm{AM}$ & 9 & 249 & 258 & 3.5 & 0.3 & 1,547 & 3,118 & 2.0 & \\
\hline $6 / 6 / 1999$ & $6: 45 \mathrm{AM}$ & 10 & 253 & 263 & 3.8 & 0.3 & 1,545 & 3,149 & 2.0 & \\
\hline $6 / 7 / 1999$ & $6: 45$ AM & 9 & 246 & 255 & 3.5 & 0.3 & 1,547 & 3,130 & 2.0 & \\
\hline $6 / 8 / 1999$ & $6: 45 \mathrm{AM}$ & 21 & 255 & 276 & 7.6 & 0.6 & 1,503 & 2,974 & 2.0 & \\
\hline $6 / 9 / 1999$ & $6: 45 \mathrm{AM}$ & 11 & 244 & 255 & 4.3 & 0.3 & 1,562 & 3,039 & 1.9 & \\
\hline $6 / 10 / 1999$ & $6: 45$ AM & 8 & 246 & 254 & 3.1 & 0.2 & 1,553 & 3,094 & 2.0 & \\
\hline $6 / 11 / 1999$ & $6: 45 \mathrm{AM}$ & 13 & 246 & 259 & 5.0 & 0.4 & 1,550 & 3,134 & 2.0 & \\
\hline $6 / 12 / 1999$ & $6: 45 \mathrm{AM}$ & 13 & 244 & 257 & 5.1 & 0.4 & 1,553 & 3,079 & 2.0 & \\
\hline $6 / 13 / 1999$ & $6: 45 \mathrm{AM}$ & 18 & 250 & 268 & 6.7 & 0.5 & 1,543 & 3,103 & 2.0 & \\
\hline $6 / 14 / 1999$ & $6: 45$ AM & 19 & 265 & 284 & 6.7 & 0.6 & 1,525 & 3,074 & 2.0 & \\
\hline $6 / 15 / 1999$ & $6: 45$ AM & 12 & 252 & 264 & 4.5 & 0.4 & 1,519 & 3,063 & 2.0 & \\
\hline $6 / 16 / 1999$ & $6: 45$ AM & 11 & 244 & 255 & 4.3 & 0.3 & 1,491 & 3,107 & 2.1 & \\
\hline $6 / 17 / 1999$ & $6: 45 \mathrm{AM}$ & 8 & 250 & 258 & 3.1 & 0.2 & 1,546 & 3,224 & 2.1 & \\
\hline $6 / 18 / 1999$ & $6: 45 \mathrm{AM}$ & 9 & 247 & 256 & 3.5 & 0.3 & 1,549 & 3,096 & 2.0 & \\
\hline $6 / 19 / 1999$ & $6: 45 \mathrm{AM}$ & 12 & 251 & 263 & 4.6 & 0.4 & 1,506 & 3,044 & 2.0 & \\
\hline $6 / 20 / 1999$ & $6: 45 \mathrm{AM}$ & 10 & 254 & 264 & 3.8 & 0.3 & 1,544 & 3,058 & 2.0 & \\
\hline $6 / 21 / 1999$ & $6: 45 \mathrm{AM}$ & 9 & 249 & 258 & 3.5 & 0.3 & 1,536 & 3,087 & 2.0 & \\
\hline $6 / 22 / 1999$ & $6: 45$ AM & 8 & 247 & 255 & 3.1 & 0.2 & 1,499 & 3,070 & 2.0 & \\
\hline $6 / 23 / 1999$ & $6: 45 \mathrm{AM}$ & 11 & 248 & 259 & 4.2 & 0.3 & 1,509 & 3,005 & 2.0 & \\
\hline $6 / 24 / 1999$ & $6: 45 \mathrm{AM}$ & 11] & 252 & 263 & 4.2 & 0.3 & 1,493 & 2,896 & 1.9 & \\
\hline
\end{tabular}


Table 1: Daily Production and Operations Data

\begin{tabular}{|c|c|c|c|c|c|c|c|c|c|c|}
\hline Date & Time & $\begin{array}{c}\text { Oil } \\
\text { Production } \\
\text { (bpd) }\end{array}$ & $\begin{array}{c}\begin{array}{c}\text { Water } \\
\text { Production } \\
\text { (bpd) }\end{array} \\
\end{array}$ & $\begin{array}{c}\text { Total Fluid } \\
\text { Production } \\
\text { (bpd) }\end{array}$ & \begin{tabular}{|c|}
$\begin{array}{c}\text { Surface } \\
\text { oil cut } \\
(\%)\end{array}$ \\
\end{tabular} & $\begin{array}{c}\text { Total } \\
\text { Oil Cut } \\
(\%) \\
\end{array}$ & $\begin{array}{c}\text { Injection } \\
\text { Pressure } \\
\text { (psi) } \\
\end{array}$ & $\begin{array}{c}\text { Injection } \\
\text { Rate } \\
\text { (bpd) } \\
\end{array}$ & $\begin{array}{l}\text { Injectivity } \\
\text { (bbl/psi) }\end{array}$ & $\begin{array}{c}\text { Annulus } \\
\text { Pressure (psi) }\end{array}$ \\
\hline $6 / 25 / 1999$ & $6: 45 \mathrm{AM}$ & 9 & 250 & 259 & 3.5 & 0.3 & 1,542 & 3,025 & 2.0 & \\
\hline $6 / 26 / 1999$ & $6: 45 \mathrm{AM}$ & 10 & 254 & 264 & 3.8 & 0.3 & 1,539 & 3,133 & 2.0 & \\
\hline $6 / 27 / 1999$ & 6:45 AM & 8 & 249 & 257 & 3.1 & 0.2 & 1,464 & 3,203 & 2.2 & \\
\hline $6 / 28 / 1999$ & $6: 45 \mathrm{AM}$ & 11 & 249 & 260 & 4.2 & 0.3 & 1,533 & 3,049 & 2.0 & \\
\hline $6 / 29 / 1999$ & 6:45 AM & 17 & 240 & 257 & 6.6 & 0.5 & 1,498 & 3,031 & 2.0 & \\
\hline $6 / 30 / 1999$ & $6: 45 \mathrm{AM}$ & 20 & 240 & 260 & 7.7 & 0.6 & 1,548 & 3,066 & 2.0 & \\
\hline $7 / 1 / 1999$ & 6:45 AM & 20 & 250 & 270 & 7.4 & 0.6 & 1,517 & 2,959 & 2.0 & \\
\hline $7 / 2 / 1999$ & $6: 45 \mathrm{AM}$ & 14 & 236 & 250 & 5.6 & 0.4 & 1,539 & 3,120 & 2.0 & \\
\hline $7 / 3 / 1999$ & $6: 45 \mathrm{AM}$ & 5 & 244 & 249 & 2.0 & 0.2 & 1,503 & 3,008 & 2.0 & \\
\hline $7 / 4 / 1999$ & $6: 45 \mathrm{AM}$ & 7 & 241 & 248 & 2.8 & 0.2 & 1,496 & 3,015 & 2.0 & \\
\hline $7 / 5 / 1999$ & 6:45 AM & 6 & 236 & 242 & 2.5 & 0.2 & 1,476 & 3,019 & 2.0 & \\
\hline $7 / 6 / 1999$ & 6:45 AM & 8 & 244 & 252 & 3.2 & 0.2 & 1,533 & 3,117 & 2.0 & \\
\hline $7 / 7 / 1999$ & $6: 45 \mathrm{AM}$ & 12 & 252 & 264 & 4.5 & 0.8 & 1,530 & 1,303 & 0.9 & \\
\hline $7 / 8 / 1999$ & 6:45 AM & 9 & 251 & 260 & 3.5 & 0.3 & 1,498 & 3,002 & 2.0 & \\
\hline $7 / 9 / 1999$ & $6: 45 \mathrm{AM}$ & 10 & 249 & 259 & 3.9 & 0.3 & 1,498 & 3,012 & 2.0 & \\
\hline $7 / 10 / 1999$ & $6: 45 \mathrm{AM}$ & 9 & 250 & 259 & 3.5 & 0.3 & 1,542 & 3,066 & 2.0 & \\
\hline $7 / 11 / 1999$ & 6:45 AM & 10 & 253 & 263 & 3.8 & 0.3 & 1,497 & 3,010 & 2.0 & \\
\hline $7 / 12 / 1999$ & $6: 45 \mathrm{AM}$ & 8 & 245 & 253 & 3.2 & 0.2 & 1,542 & 3,063 & 2.0 & \\
\hline $7 / 13 / 1999$ & $6: 45 \mathrm{AM}$ & 4 & 250 & 254 & 1.6 & 0.1 & 1,466 & 3,061 & 2.1 & \\
\hline $7 / 14 / 1999$ & 6:45 AM & 6 & 240 & 246 & 2.4 & 0.2 & 1,494 & 3,045 & 2.0 & \\
\hline $7 / 15 / 1999$ & $6: 45 \mathrm{AM}$ & 7 & 258 & 265 & 2.6 & 0.2 & 1,539 & 3,073 & 2.0 & \\
\hline $7 / 16 / 1999$ & $6: 45 \mathrm{AM}$ & 12 & 251 & 263 & 4.6 & 0.4 & 1,506 & 2,967 & 2.0 & \\
\hline $7 / 17 / 1999$ & $6: 45 \mathrm{AM}$ & 13 & 271 & 284 & 4.6 & 0.4 & 1,510 & 2,996 & 2.0 & \\
\hline $7 / 18 / 1999$ & $6: 45 \mathrm{AM}$ & 9 & 265 & 274 & 3.3 & 0.3 & 1,498 & 3,033 & 2.0 & \\
\hline
\end{tabular}


Table 1: Daily Production and Operations Data

\begin{tabular}{|c|c|c|c|c|c|c|c|c|c|c|}
\hline Date & Time & $\begin{array}{c}\text { Oil } \\
\text { Production } \\
\text { (bpd) }\end{array}$ & $\begin{array}{c}\text { Water } \\
\text { Production } \\
\text { (bpd) }\end{array}$ & \begin{tabular}{|c|}
$\begin{array}{c}\text { Total Fluid } \\
\text { Production } \\
\text { (bpd) }\end{array}$ \\
\end{tabular} & $\begin{array}{c}\text { Surface } \\
\text { oil cut } \\
(\%)\end{array}$ & $\begin{array}{c}\text { Total } \\
\text { Oil Cut } \\
(\%)\end{array}$ & $\begin{array}{c}\text { Injection } \\
\text { Pressure } \\
\text { (psi) }\end{array}$ & $\begin{array}{c}\text { Injection } \\
\text { Rate } \\
\text { (bpd) } \\
\end{array}$ & $\begin{array}{c}\text { Injectivity } \\
\text { (bbl/psi) }\end{array}$ & $\begin{array}{c}\text { Annulus } \\
\text { Pressure (psi) }\end{array}$ \\
\hline $7 / 19 / 1999$ & 6:45 AM & 6 & 272 & 278 & 2.2 & 0.2 & 1,539 & 3,131 & 2.0 & \\
\hline $7 / 20 / 1999$ & $6: 45 \mathrm{AM}$ & 8 & 261 & 269 & 3.0 & 0.2 & 1,467 & 3,126 & 2.1 & \\
\hline $7 / 21 / 1999$ & $6: 45 \mathrm{AM}$ & 10 & 254 & 264 & 3.8 & 0.3 & 1,473 & 3,044 & 2.1 & \\
\hline $7 / 22 / 1999$ & $6: 45 \mathrm{AM}$ & 7 & 257 & 264 & 2.7 & 0.2 & 1,477 & 2,976 & 2.0 & \\
\hline $7 / 23 / 1999$ & 6:45 AM & 8 & 255 & 263 & 3.0 & 0.2 & 1,531 & 3,115 & 2.0 & \\
\hline $7 / 24 / 1999$ & $6: 45 \mathrm{AM}$ & 9 & 250 & 259 & 3.5 & 0.3 & 1,500 & 3,041 & 2.0 & \\
\hline $7 / 25 / 1999$ & $6: 45 \mathrm{AM}$ & 11 & 247 & 258 & 4.3 & 0.3 & 1,511 & 3,105 & 2.1 & \\
\hline $7 / 26 / 1999$ & $6: 45 \mathrm{AM}$ & 7 & 228 & 235 & 3.0 & 0.2 & 1,501 & 3,018 & 2.0 & \\
\hline $7 / 27 / 1999$ & 6:45 AM & 10 & 239 & 249 & 4.0 & 0.3 & 1,578 & 3,081 & 2.0 & \\
\hline $7 / 28 / 1999$ & 6:45 AM & 7 & 229 & 236 & 3.0 & 0.2 & 1,500 & 3,046 & 2.0 & \\
\hline $7 / 29 / 1999$ & $6: 45 \mathrm{AM}$ & 11 & 223 & 234 & 4.7 & 0.3 & 1,467 & 3,029 & 2.1 & \\
\hline $7 / 30 / 1999$ & 6:45 AM & 11 & 234 & 245 & 4.5 & 0.3 & 1,497 & 3,083 & 2.1 & \\
\hline 7/31/1999 & $6: 45 \mathrm{AM}$ & 6 & 234 & 240 & 2.5 & 0.2 & 1,510 & 2,969 & 2.0 & \\
\hline $8 / 1 / 1999$ & 6:45 AM & 15 & 227 & 242 & 6.2 & 0.5 & 1,505 & 2,914 & 1.9 & \\
\hline $8 / 2 / 1999$ & $6: 45 \mathrm{AM}$ & 14 & 241 & 255 & 5.5 & 0.4 & 1,550 & 3,063 & 2.0 & \\
\hline $8 / 3 / 1999$ & $6: 45 \mathrm{AM}$ & 11 & 253 & 264 & 4.2 & 0.3 & 1,560 & 3,103 & 2.0 & \\
\hline $8 / 4 / 1999$ & $6: 45 \mathrm{AM}$ & 9 & 258 & 267 & 3.4 & 0.3 & 1,503 & 3,016 & 2.0 & \\
\hline $8 / 5 / 1999$ & $6: 45 \mathrm{AM}$ & 8 & 248 & 256 & 3.1 & 0.2 & 1,545 & 3,137 & 2.0 & \\
\hline $8 / 6 / 1999$ & 6:45 AM & 7 & 252 & 259 & 2.7 & 0.2 & 1,540 & 3,126 & 2.0 & \\
\hline $8 / 7 / 1999$ & $6: 45 \mathrm{AM}$ & 6 & 240 & 246 & 2.4 & 0.2 & & 3,104 & 0.0 & \\
\hline $8 / 8 / 1999$ & $6: 45 \mathrm{AM}$ & 8 & 252 & 260 & 3.1 & 0.2 & & 3,104 & 0.0 & \\
\hline $8 / 9 / 1999$ & $6: 45 \mathrm{AM}$ & 12 & 240 & 252 & 4.8 & 0.4 & & 3,104 & 0.0 & \\
\hline $8 / 10 / 1999$ & 6:45 AM & 18 & 250 & 268 & 6.7 & 0.5 & & 3,104 & 0.0 & \\
\hline $8 / 11 / 1999$ & $6: 45$ AM & 6 & 240 & 246 & 2.4 & 0.2 & 1,588 & 3,017 & 1.9 & \\
\hline
\end{tabular}


Table 1: Daily Production and Operations Data

\begin{tabular}{|c|c|c|c|c|c|c|c|c|c|c|}
\hline Date & Time & $\begin{array}{c}\text { Oil } \\
\text { Production } \\
\text { (bpd) }\end{array}$ & $\begin{array}{c}\begin{array}{c}\text { Water } \\
\text { Production } \\
\text { (bpd) }\end{array} \\
\end{array}$ & $\begin{array}{c}\text { Total Fluid } \\
\text { Production } \\
\text { (bpd) }\end{array}$ & \begin{tabular}{|c|} 
Surface \\
oil cut \\
$(\%)$
\end{tabular} & $\begin{array}{c}\text { Total } \\
\text { Oil Cut } \\
(\%)\end{array}$ & $\begin{array}{c}\text { Injection } \\
\text { Pressure } \\
\text { (psi) } \\
\end{array}$ & $\begin{array}{c}\text { Injection } \\
\text { Rate } \\
\text { (bpd) }\end{array}$ & $\begin{array}{c}\text { Injectivity } \\
\text { (bbl/psi) }\end{array}$ & $\begin{array}{c}\text { Annulus } \\
\text { Pressure (psi) }\end{array}$ \\
\hline $8 / 12 / 1999$ & $6: 45 \mathrm{AM}$ & 10 & 245 & $\begin{array}{r}255 \\
\end{array}$ & 3.9 & $\begin{array}{l}0.3 \\
\end{array}$ & $\begin{array}{r}1,497 \\
\end{array}$ & 2,945 & $\begin{array}{r}2.0 \\
\end{array}$ & \\
\hline $8 / 13 / 1999$ & $6: 45 \mathrm{AM}$ & 14 & 234 & 248 & 5.6 & 0.4 & 1,503 & 2,878 & 1.9 & \\
\hline $8 / 14 / 1999$ & $6: 45 \mathrm{AM}$ & 8 & 242 & 250 & 3.2 & 0.2 & 1,552 & 3,069 & 2.0 & \\
\hline $8 / 15 / 1999$ & $6: 45 \mathrm{AM}$ & 11 & 221 & 232 & 4.7 & 0.3 & 1,547 & 3,084 & 2.0 & \\
\hline $8 / 16 / 1999$ & $6: 45 \mathrm{AM}$ & 10 & 232 & 242 & 4.1 & 0.3 & 1,500 & 3,001 & 2.0 & \\
\hline $8 / 17 / 1999$ & $6: 45 \mathrm{AM}$ & 7 & 241 & 248 & 2.8 & 0.2 & 1,468 & 3,027 & 2.1 & \\
\hline $8 / 18 / 1999$ & 6:45 AM & 8 & 246 & 254 & 3.1 & 0.2 & 1,499 & 3,022 & 2.0 & \\
\hline $8 / 19 / 1999$ & $6: 45 \mathrm{AM}$ & 10 & 238 & 248 & 4.0 & 0.3 & 1,494 & 3,008 & 2.0 & \\
\hline $8 / 20 / 1999$ & 6:45 AM & 12 & 240 & 252 & 4.8 & 0.4 & 1,503 & 2,932 & 2.0 & \\
\hline $8 / 21 / 1999$ & $6: 45 \mathrm{AM}$ & 8 & 246 & 254 & 3.1 & 0.2 & 1,414 & 3,205 & 2.3 & \\
\hline $8 / 22 / 1999$ & $6: 45 \mathrm{AM}$ & 16 & 250 & 266 & 6.0 & 0.5 & 1,498 & 2,932 & 2.0 & \\
\hline $8 / 23 / 1999$ & $6: 45 \mathrm{AM}$ & 5 & 248 & 253 & 2.0 & 0.2 & 1,499 & 2,977 & 2.0 & \\
\hline $8 / 24 / 1999$ & $6: 45 \mathrm{AM}$ & 6 & 240 & 246 & 2.4 & 0.2 & 1,490 & 2,940 & 2.0 & \\
\hline $8 / 25 / 1999$ & 6:45 AM & 6 & 240 & 246 & 2.4 & 0.2 & 1,510 & 2,916 & 1.9 & \\
\hline $8 / 26 / 1999$ & $6: 45$ AM & 10 & 250 & 260 & 3.8 & 0.3 & 1,502 & 2,996 & 2.0 & \\
\hline $8 / 27 / 1999$ & $6: 45 \mathrm{AM}$ & 16 & 239 & 255 & 6.3 & 0.5 & 1,504 & 2,972 & 2.0 & \\
\hline $8 / 28 / 1999$ & $6: 45 \mathrm{AM}$ & 9 & 248 & 257 & 3.5 & 0.3 & 1,533 & 3,060 & 2.0 & \\
\hline $8 / 29 / 1999$ & $6: 45 \mathrm{AM}$ & 14 & 241 & 255 & 5.5 & 0.4 & 1,497 & 2,949 & 2.0 & \\
\hline $8 / 30 / 1999$ & $6: 45 \mathrm{AM}$ & 22 & 232 & 254 & 8.7 & 0.7 & 1,499 & 2,879 & 1.9 & \\
\hline $8 / 31 / 1999$ & $6: 45 \mathrm{AM}$ & 16 & 244 & 260 & 6.2 & 0.5 & 1,497 & 2,999 & 2.0 & \\
\hline $9 / 1 / 1999$ & 6:45 AM & 21 & 229 & 250 & 8.4 & 0.7 & 1,515 & 2,930 & 1.9 & \\
\hline $9 / 2 / 1999$ & Down & & & & 0.0 & 0.0 & & & 0.0 & \\
\hline $9 / 3 / 1999$ & 6:45 AM & 6 & 220 & 226 & 2.7 & 0.0 & & No Data & 0.0 & \\
\hline $9 / 4 / 1999$ & $6: 45 \mathrm{AM}$ & 6 & 228 & 234 & 2.6 & 0.2 & 1,499 & 2,969 & 2.0 & \\
\hline
\end{tabular}


Table 1: Daily Production and Operations Data

\begin{tabular}{|c|c|c|c|c|c|c|c|c|c|c|}
\hline Date & Time & $\begin{array}{c}\text { Oil } \\
\text { Production } \\
\text { (bpd) }\end{array}$ & $\begin{array}{c}\begin{array}{c}\text { Water } \\
\text { Production } \\
\text { (bpd) }\end{array} \\
\end{array}$ & $\begin{array}{c}\text { Total Fluid } \\
\text { Production } \\
\text { (bpd) }\end{array}$ & $\begin{array}{c}\text { Surface } \\
\text { oil cut } \\
(\%)\end{array}$ & $\begin{array}{c}\text { Total } \\
\text { Oil Cut } \\
\text { (\%) }\end{array}$ & $\begin{array}{c}\text { Injection } \\
\text { Pressure } \\
\text { (psi) }\end{array}$ & $\begin{array}{c}\text { Injection } \\
\text { Rate } \\
\text { (bpd) } \\
\end{array}$ & $\begin{array}{c}\text { Injectivity } \\
\text { (bbl/psi) }\end{array}$ & $\begin{array}{c}\text { Annulus } \\
\text { Pressure (psi) }\end{array}$ \\
\hline $9 / 5 / 1999$ & 6:45 AM & 6 & 230 & 236 & 2.5 & 0.2 & 1,585 & 2,982 & 1.9 & \\
\hline $9 / 6 / 1999$ & 6:45 AM & 11 & 242 & 253 & 4.3 & 0.3 & 1,507 & 2,976 & 2.0 & \\
\hline $9 / 7 / 1999$ & 6:45 AM & 16 & 238 & 254 & 6.3 & 0.5 & 1,535 & 3,098 & 2.0 & \\
\hline $9 / 8 / 1999$ & $6: 45 \mathrm{AM}$ & 16 & 240 & 256 & 6.3 & 0.5 & 1,497 & 3,073 & 2.1 & \\
\hline 9/9/1999 & 6:45 AM & 15 & 232 & 247 & 6.1 & 0.5 & 1,499 & 2,986 & 2.0 & \\
\hline $9 / 10 / 1999$ & $6: 45 \mathrm{AM}$ & 12 & 241 & 253 & 4.7 & 0.4 & 1,512 & 3,021 & 2.0 & \\
\hline $9 / 11 / 1999$ & 6:45 AM & 13 & 238 & 251 & 5.2 & 0.4 & 1,560 & 3,035 & 1.9 & \\
\hline $9 / 12 / 1999$ & $6: 45 \mathrm{AM}$ & 18 & 233 & 251 & 7.2 & 0.5 & 1,544 & 3,147 & 2.0 & \\
\hline $9 / 13 / 1999$ & 6:45 AM & 11 & 244 & 255 & 4.3 & 0.3 & 1,547 & 3,087 & 2.0 & \\
\hline $9 / 14 / 1999$ & $6: 45 \mathrm{AM}$ & 12 & 246 & 258 & 4.7 & 0.4 & 1,487 & 3,119 & 2.1 & \\
\hline $9 / 15 / 1999$ & $6: 45 \mathrm{AM}$ & 14 & 239 & 253 & 5.5 & 0.4 & 1,536 & 2,928 & 1.9 & \\
\hline $9 / 16 / 1999$ & 6:45 AM & 13 & 241 & 254 & 5.1 & 0.4 & 1,609 & 2,923 & 1.8 & \\
\hline $9 / 17 / 1999$ & $6: 45 \mathrm{AM}$ & 8 & 245 & 253 & 3.2 & 0.3 & 1,644 & 2,934 & 1,8 & \\
\hline $9 / 18 / 1999$ & 6:45 AM & 7 & 313 & 320 & 2.2 & 0.2 & 1,594 & 3,017 & 1.9 & \\
\hline $9 / 19 / 1999$ & $6: 45 \mathrm{AM}$ & 5 & 310 & 315 & 1.6 & 0.1 & 1,609 & 3,051 & 1.9 & \\
\hline $9 / 20 / 1999$ & $6: 45 \mathrm{AM}$ & 8 & 312 & 320 & 2.5 & 0.2 & 1,607 & 3,051 & 1.9 & \\
\hline $9 / 21 / 1999$ & 6:45 AM & 7 & 313 & 320 & 2.2 & 0.2 & 1,584 & 3,388 & 2.1 & \\
\hline $9 / 22 / 1999$ & $6: 45 \mathrm{AM}$ & 5 & 250 & 255 & 2.0 & 0.1 & 1,624 & 3,214 & 2.0 & \\
\hline $9 / 23 / 1999$ & 6:45 AM & 6 & 260 & 266 & 2.3 & 0.2 & 1,616 & 3,394 & 2.1 & \\
\hline $9 / 24 / 1999$ & $6: 45$ AM & 7 & 261 & 268 & 2.6 & 0.2 & 1,632 & 3,473 & 2.1 & \\
\hline $9 / 25 / 1999$ & 6:45 AM & 7 & 257 & 264 & 2.7 & 0.2 & 1,649 & 3,571 & 2.2 & \\
\hline $9 / 26 / 1999$ & 6:45 AM & 12 & 395 & 407 & 2.9 & 0.3 & 1,668 & 3,601 & 2.2 & \\
\hline $9 / 27 / 1999$ & 6:45 AM & 9 & 369 & 378 & 2.4 & 0.2 & 1,670 & 3,731 & 2.2 & \\
\hline $9 / 28 / 1999$ & $6: 45 \mathrm{AM}$ & 8 & 372 & 380 & 2.1 & 0.2 & 1,695 & 3,699 & 2.2 & \\
\hline
\end{tabular}


Table 1: Daily Production and Operations Data

\begin{tabular}{|c|c|c|c|c|c|c|c|c|c|c|}
\hline Date & Time & $\begin{array}{c}\text { Oil } \\
\text { Production } \\
\text { (bpd) }\end{array}$ & $\begin{array}{c}\text { Water } \\
\text { Production } \\
\text { (bpd) }\end{array}$ & $\begin{array}{c}\text { Total Fluid } \\
\text { Production } \\
\text { (bpd) }\end{array}$ & $\begin{array}{c}\text { Surface } \\
\text { oil cut } \\
(\%)\end{array}$ & $\begin{array}{c}\text { Total } \\
\text { Oil Cut } \\
(\%)\end{array}$ & $\begin{array}{c}\text { Injection } \\
\text { Pressure } \\
\text { (psi) }\end{array}$ & $\begin{array}{c}\text { Injection } \\
\text { Rate } \\
\text { (bpd) } \\
\end{array}$ & $\begin{array}{c}\text { Injectivity } \\
\text { (bbl/psi) }\end{array}$ & $\begin{array}{c}\text { Annulus } \\
\text { Pressure (psi) }\end{array}$ \\
\hline $9 / 29 / 1999$ & 6:45 AM & 7 & 391 & 398 & 1.8 & 0.2 & 1,686 & 3,853 & 2.3 & \\
\hline $9 / 30 / 1999$ & $6: 45 \mathrm{AM}$ & 2 & 201 & 203 & 1.0 & 0.1 & 1,516 & 3,425 & 2.3 & \\
\hline $10 / 1 / 1999$ & $6: 45$ AM & 7 & 300 & 307 & 2.3 & 0.2 & 1,518 & 3,373 & 2.2 & \\
\hline $10 / 2 / 1999$ & $6: 45 \mathrm{AM}$ & 7 & 301 & 308 & 2.3 & 0.2 & 1,502 & 3,444 & 2.3 & \\
\hline $10 / 3 / 1999$ & $6: 45 \mathrm{AM}$ & 7 & 300 & 307 & 2.3 & 0.2 & 1,504 & 3,515 & 2.3 & \\
\hline $10 / 4 / 1999$ & $6: 45 \mathrm{AM}$ & 7 & 304 & 311 & 2.3 & 0.2 & 1,504 & 3,526 & 2.3 & \\
\hline $10 / 5 / 1999$ & $6: 45 \mathrm{AM}$ & 5 & 249 & 254 & 2.0 & 0.1 & 1,417 & 3,257 & 2.3 & \\
\hline $10 / 6 / 1999$ & $6: 45 \mathrm{AM}$ & 6 & 249 & 255 & 2.4 & 0.2 & 1,415 & 3,276 & 2.3 & \\
\hline $10 / 7 / 1999$ & $6: 45 \mathrm{AM}$ & 6 & 250 & 256 & 2.3 & 0.2 & 1,416 & 3,281 & 2.3 & \\
\hline $10 / 8 / 1999$ & $6: 45 \mathrm{AM}$ & 5 & 261 & 266 & 1.9 & 0.1 & 1,417 & 3,273 & 2.3 & \\
\hline $10 / 9 / 1999$ & $6: 45 \mathrm{AM}$ & 5 & 253 & 258 & 1.9 & 0.1 & 1,410 & 3,313 & 2.3 & \\
\hline $10 / 10 / 1999$ & $6: 45 \mathrm{AM}$ & 6 & 254 & 260 & 2.3 & 0.2 & 1,406 & 3,322 & 2.4 & \\
\hline $10 / 11 / 1999$ & 6:45 AM & 6 & 251 & 257 & 2.3 & 0.2 & 1,402 & 3,298 & 2.4 & \\
\hline $10 / 12 / 1999$ & 6:45 AM & 7 & 255 & 262 & 2.7 & 0.2 & 1,402 & 3,297 & 2.4 & \\
\hline $10 / 13 / 1999$ & $6: 45 \mathrm{AM}$ & 6 & 249 & 255 & 2.4 & 0.2 & 1,400 & 3,288 & 2.3 & \\
\hline $10 / 14 / 1999$ & 6:45 AM & 6 & 260 & 266 & 2.3 & 0.2 & 1,392 & 3,320 & 2.4 & \\
\hline $10 / 15 / 1999$ & 6:45 AM & 5 & 258 & 263 & 1.9 & 0.1 & 1,398 & 3,404 & 2.4 & \\
\hline $10 / 16 / 1999$ & 6:45 AM & 5 & 249 & 254 & 2.0 & 0.1 & 1,398 & 3,378 & 2.4 & \\
\hline $10 / 17 / 1999$ & $6: 45 \mathrm{AM}$ & 4 & 246 & 250 & 1.6 & 0.1 & 1,397 & 3,397 & 2.4 & \\
\hline $10 / 18 / 1999$ & $6: 45 \mathrm{AM}$ & 4 & 245 & 249 & 1.6 & 0.1 & 1,400 & 3,376 & 2.4 & \\
\hline $10 / 19 / 1999$ & $6: 45 \mathrm{AM}$ & 3 & 244 & 247 & 1.2 & 0.1 & 1,398 & 3,381 & 2.4 & \\
\hline $10 / 20 / 1999$ & $6: 45 \mathrm{AM}$ & 6 & 240 & 246 & 2.4 & 0.2 & 1,399 & 3,370 & 2.4 & \\
\hline $10 / 21 / 1999$ & $6: 45 \mathrm{AM}$ & 4 & 243 & 247 & 1.6 & 0.1 & 1,397 & 3,380 & 2.4 & \\
\hline $10 / 22 / 1999$ & $6: 45 \mathrm{AM}$ & 8 & 246 & 254 & 3.1 & 0.2 & 1,397 & 3,374 & 2.4 & \\
\hline
\end{tabular}


Table 1: Daily Production and Operations Data

\begin{tabular}{|c|c|c|c|c|c|c|c|c|c|c|}
\hline Date & Time & $\begin{array}{c}\text { Oil } \\
\text { Production } \\
\text { (bpd) }\end{array}$ & $\begin{array}{c}\begin{array}{c}\text { Water } \\
\text { Production } \\
\text { (bpd) }\end{array} \\
\end{array}$ & $\begin{array}{c}\text { Total Fluid } \\
\text { Production } \\
\text { (bpd) }\end{array}$ & $\begin{array}{c}\text { Surface } \\
\text { oil cut } \\
(\%)\end{array}$ & \begin{tabular}{|c|} 
Total \\
Oil Cut \\
$(\%)$
\end{tabular} & $\begin{array}{c}\text { Injection } \\
\text { Pressure } \\
\text { (psi) }\end{array}$ & \begin{tabular}{|c|} 
Injection \\
Rate \\
(bpd) \\
\end{tabular} & $\begin{array}{l}\text { Injectivity } \\
\text { (bbl/psi) }\end{array}$ & $\begin{array}{c}\text { Annulus } \\
\text { Pressure (psi) }\end{array}$ \\
\hline $10 / 23 / 1999$ & $6: 45 \mathrm{AM}$ & 5 & 249 & 254 & 2.0 & 0.1 & 1,397 & 3,370 & 2.4 & \\
\hline $10 / 24 / 1999$ & $6: 45 \mathrm{AM}$ & 10 & 246 & 256 & 3.9 & 0.3 & 1,395 & 3,380 & 2.4 & \\
\hline $10 / 25 / 1999$ & $6: 45$ AM & 11 & 249 & 260 & 4.2 & 0.3 & 1,399 & 3,399 & 2.4 & \\
\hline $10 / 26 / 1999$ & $6: 45$ AM & 9 & 252 & 261 & 3.4 & 0.2 & 1,397 & 3,391 & 2.4 & \\
\hline $10 / 27 / 1999$ & $6: 45 \mathrm{AM}$ & 7 & 256 & 263 & 2.7 & 0.2 & 1,395 & 3,400 & 2.4 & \\
\hline $10 / 28 / 1999$ & $6: 45 \mathrm{AM}$ & 10 & 245 & 255 & 3.9 & 0.3 & 1,395 & 3,393 & 2.4 & \\
\hline $10 / 29 / 1999$ & $6: 45$ AM & 5 & 249 & 254 & 2.0 & 0.1 & 1,396 & 3,375 & 2.4 & \\
\hline $10 / 30 / 1999$ & $6: 45 \mathrm{AM}$ & 13 & 248 & 261 & 5.0 & 0.4 & 1,394 & 3,387 & 2.4 & \\
\hline $10 / 31 / 1999$ & $6: 45$ AM & 9 & 251 & 260 & 3.5 & 0.2 & 1,395 & 3,384 & 2.4 & \\
\hline $11 / 1 / 1999$ & $6: 45 \mathrm{AM}$ & 5 & 242 & 247 & 2.0 & 0.1 & 1,391 & 3,410 & 2.5 & \\
\hline 11/2/1999 & $6: 45 \mathrm{AM}$ & 4 & 240 & 244 & 1.6 & 0.1 & 1,399 & 3,340 & 2.4 & \\
\hline $11 / 3 / 1999$ & $6: 45 \mathrm{AM}$ & 6 & 252 & 258 & 2.3 & 0.2 & 1,397 & 3,351 & 2.4 & \\
\hline $11 / 4 / 1999$ & $6: 45 \mathrm{AM}$ & 3 & 245 & 248 & 1.2 & 0.1 & 1,394 & 3,376 & 2.4 & \\
\hline $11 / 5 / 1999$ & $6: 45$ AM & 9 & 244 & 253 & 3.6 & 0.2 & 1,395 & 3,382 & 2.4 & \\
\hline $11 / 6 / 1999$ & $6: 45 \mathrm{AM}$ & 8 & 240 & 248 & 3.2 & 0.2 & 1,397 & 3,360 & 2.4 & \\
\hline $11 / 7 / 1999$ & $6: 45$ AM & 5 & 251 & 256 & 2.0 & 0.1 & 1,396 & 3,372 & 2.4 & \\
\hline $11 / 8 / 1999$ & $6: 45$ AM & 16 & 244 & 260 & 6.2 & 0.4 & 1,399 & 3,373 & 2.4 & \\
\hline $11 / 9 / 1999$ & $6: 45 \mathrm{AM}$ & 12 & 248 & 260 & 4.6 & 0.3 & 1,393 & 3,416 & 2.5 & \\
\hline $11 / 10 / 1999$ & $6: 45$ AM & 14 & 251 & 265 & 5.3 & 0.4 & 1,396 & 3,378 & 2.4 & \\
\hline $11 / 11 / 1999$ & $6: 45 \mathrm{AM}$ & 10 & 244 & 254 & 3.9 & 0.3 & 1,399 & 3,373 & 2.4 & \\
\hline $11 / 12 / 1999$ & $6: 45 \mathrm{AM}$ & 5 & 250 & 255 & 2.0 & 0.1 & 1,397 & 3,377 & 2.4 & \\
\hline $11 / 13 / 1999$ & $6: 45 \mathrm{AM}$ & 10 & 241 & 251 & 4.0 & 0.3 & 1,398 & 3,363 & 2.4 & \\
\hline $11 / 14 / 1999$ & $6: 45 \mathrm{AM}$ & 13 & 245 & 258 & 5.0 & 0.4 & 1,396 & 3,372 & 2.4 & \\
\hline $11 / 15 / 1999$ & $6: 45$ AM & 13 & 244 & 257 & 5.1 & 0.4 & 1,397 & 3,377 & 2.4 & \\
\hline
\end{tabular}


Table 1: Daily Production and Operations Data

\begin{tabular}{|c|c|c|c|c|c|c|c|c|c|c|}
\hline Date & Time & $\begin{array}{c}\text { Oil } \\
\text { Production } \\
\text { (bpd) }\end{array}$ & $\begin{array}{c}\text { Water } \\
\text { Production } \\
\text { (bpd) }\end{array}$ & $\begin{array}{c}\text { Total Fluid } \\
\text { Production } \\
\text { (bpd) }\end{array}$ & \begin{tabular}{|c|} 
Surface \\
oil cut \\
$(\%)$
\end{tabular} & $\begin{array}{c}\text { Total } \\
\text { Oil Cut } \\
(\%)\end{array}$ & $\begin{array}{c}\text { Injection } \\
\begin{array}{c}\text { Pressure } \\
\text { (psi) }\end{array} \\
\end{array}$ & $\begin{array}{c}\text { Injection } \\
\text { Rate } \\
\text { (bpd) } \\
\end{array}$ & $\begin{array}{c}\text { Injectivity } \\
\text { (bbl/psi) }\end{array}$ & $\begin{array}{c}\text { Annulus } \\
\text { Pressure (psi) }\end{array}$ \\
\hline $11 / 16 / 1999$ & $6: 45 \mathrm{AM}$ & 10 & 248 & 258 & 3.9 & 0.3 & 1,393 & 3,373 & 2.4 & \\
\hline $11 / 17 / 1999$ & $6: 45 \mathrm{AM}$ & 13 & 243 & 256 & 5.1 & 0.4 & 1,397 & 3,370 & 2.4 & \\
\hline $11 / 18 / 1999$ & $6: 45 \mathrm{AM}$ & 10 & 244 & 254 & 3.9 & 0.3 & 1,396 & 3,377 & 2.4 & \\
\hline $11 / 19 / 1999$ & $6: 45 \mathrm{AM}$ & 11 & 251 & 262 & 4.2 & 0.3 & 1,397 & 3,370 & 2.4 & \\
\hline $11 / 20 / 1999$ & $6: 45 \mathrm{AM}$ & 12 & 247 & 259 & 4.6 & 0.3 & 1,393 & 3,413 & 2.5 & \\
\hline $11 / 21 / 1999$ & $6: 45 \mathrm{AM}$ & 12 & 245 & 257 & 4.7 & 0.3 & 1,397 & 3,376 & 2.4 & \\
\hline $11 / 22 / 1999$ & $6: 45 \mathrm{AM}$ & 14 & 249 & 263 & 5.3 & 0.4 & 1,396 & 3,391 & 2.4 & \\
\hline $11 / 23 / 1999$ & $6: 45 \mathrm{AM}$ & 13 & 245 & 258 & 5.0 & 0.4 & 1,396 & 3,393 & 2.4 & \\
\hline $11 / 24 / 1999$ & $6: 45 \mathrm{AM}$ & 12 & 248 & 260 & 4.6 & 0.3 & 1,391 & 3,427 & 2.5 & \\
\hline $11 / 25 / 1999$ & $6: 45 \mathrm{AM}$ & 14 & 242 & 256 & 5.5 & 0.4 & 1,398 & 3,360 & 2.4 & \\
\hline $11 / 26 / 1999$ & $6: 45 \mathrm{AM}$ & 12 & 247 & 259 & 4.6 & 0.3 & 1,396 & 3,383 & 2.4 & \\
\hline $11 / 27 / 1999$ & $6: 45$ AM & 13 & 241 & 254 & 5.1 & 0.4 & 1,395 & 3,383 & 2.4 & \\
\hline $11 / 28 / 1999$ & $6: 45 \mathrm{AM}$ & 12 & 243 & 255 & 4.7 & 0.3 & 1,398 & 3,370 & 2.4 & \\
\hline $11 / 29 / 1999$ & $6: 45 \mathrm{AM}$ & 13 & 244 & 257 & 5.1 & 0.4 & 1,395 & 3,387 & 2.4 & \\
\hline $11 / 30 / 1999$ & $6: 45 \mathrm{AM}$ & 13 & 248 & 261 & 5.0 & 0.4 & 1,396 & 3,384 & 2.4 & \\
\hline $12 / 1 / 1999$ & $6: 45 \mathrm{AM}$ & 12 & 244 & 256 & 4.7 & 0.3 & 1,396 & 3,396 & 2.4 & \\
\hline $12 / 2 / 1999$ & $6: 45$ AM & 13 & 240 & 253 & 5.1 & 0.4 & 1,396 & 3,368 & 2.4 & \\
\hline $12 / 3 / 1999$ & $6: 45 \mathrm{AM}$ & 15 & 251 & 266 & 5.6 & 0.4 & 1,399 & 3,337 & 2.4 & \\
\hline $12 / 4 / 1999$ & $6: 45 \mathrm{AM}$ & 13 & 238 & 251 & 5.2 & 0.4 & 1,395 & 3,371 & 2.4 & \\
\hline $12 / 5 / 1999$ & $6: 45 \mathrm{AM}$ & 14 & 249 & 263 & 5.3 & 0.4 & 1,391 & 3,397 & 2.4 & \\
\hline $12 / 6 / 1999$ & $6: 45 \mathrm{AM}$ & 12 & 255 & 267 & 4.5 & 0.3 & 1,393 & 3,386 & 2.4 & \\
\hline $12 / 7 / 1999$ & $6: 45 \mathrm{AM}$ & 11 & 250 & 261 & 4.2 & 0.3 & 1,400 & 3,352 & 2.4 & \\
\hline $12 / 8 / 1999$ & $6: 45 \mathrm{AM}$ & 13 & 247 & 260 & 5.0 & 0.4 & 1,393 & 3,410 & 2.4 & \\
\hline $12 / 9 / 1999$ & $6: 45 \mathrm{AM}$ & 10 & 242 & 252 & 4.0 & 0.3 & 1,397 & 3,375 & 2.4 & \\
\hline
\end{tabular}


Table 1: Daily Production and Operations Data

\begin{tabular}{|c|cc|c|c|c|c|c|c|c|c|}
\hline Date & Time & $\begin{array}{c}\text { Oil } \\
\text { Production } \\
\text { (bpd) }\end{array}$ & $\begin{array}{c}\text { Water } \\
\text { Production } \\
\text { (bpd) }\end{array}$ & $\begin{array}{c}\text { Total Fluid } \\
\text { Production } \\
\text { (bpd) }\end{array}$ & $\begin{array}{c}\text { Surface } \\
\text { oil cut } \\
\text { (\%) }\end{array}$ & $\begin{array}{c}\text { Total } \\
\text { oil Cut } \\
\text { (\%) }\end{array}$ & $\begin{array}{c}\text { Injection } \\
\text { Pressure } \\
\text { (psi) }\end{array}$ & $\begin{array}{c}\text { Injection } \\
\text { Rate } \\
\text { (bpd) }\end{array}$ & $\begin{array}{c}\text { Annulus } \\
\text { Injectivity } \\
\text { (bbl/psi) }\end{array}$ & $\begin{array}{c}\text { Anessure (psi) } \\
\text { Press }\end{array}$ \\
\hline $12 / 10 / 1999$ & & $6: 45 \mathrm{AM}$ & 10 & 249 & 259 & 3.9 & 0.3 & 1,395 & 3,377 & 2.4 \\
\hline
\end{tabular}


Table 2 - Production and Productivity Index

\begin{tabular}{|c|c|c|c|l|}
\hline Date & $\begin{array}{c}\text { Total Production } \\
\text { (bpd) }\end{array}$ & $\begin{array}{c}\text { Annulus } \\
\text { Pressure } \\
\text { (psi) }\end{array}$ & $\begin{array}{c}\text { Pressure Drop } \\
\text { from Static }{ }^{{ }^{2}}\end{array}$ & $\begin{array}{c}\text { Productivity } \\
\text { (psi) }\end{array}$ \\
\hline $10 / 29 / 98$ & 3,780 & 818 & 12 & 315 \\
\hline $10 / 30 / 98$ & 3,265 & 822 & 8 & 408 \\
\hline $10 / 31 / 98$ & 2,834 & 822 & 8 & 354 \\
\hline $11 / 2 / 98$ & 2,401 & 825 & 5 & 480 \\
\hline $11 / 5 / 98$ & 2,298 & 825 & 5 & 460 \\
\hline \multicolumn{2}{|r|}{ Average Productivity Index } & & & $442 \mathrm{bpd} / \mathrm{psi}$ \\
\hline
\end{tabular}

Static pressure was 830 psi.

Table 3 - Production Summary: October 29 to November 15, 1998

\begin{tabular}{|c|c|l|c|c|c|}
\hline $\begin{array}{c}\text { Production } \\
\text { Period }\end{array}$ & $\begin{array}{c}\text { Average } \\
\text { Oil } \\
\text { Produced } \\
\text { (bpd) }\end{array}$ & $\begin{array}{l}\text { Average } \\
\text { Water } \\
\text { Produced } \\
\text { to Surface } \\
\text { (bpd) }\end{array}$ & $\begin{array}{c}\text { Average } \\
\text { Water } \\
\text { Injected } \\
\text { (bpd) }\end{array}$ & $\begin{array}{c}\text { Average } \\
\text { Total Water } \\
\text { Produced } \\
\text { (bpd) }\end{array}$ & $\begin{array}{c}\text { Average } \\
\text { Oil Cut (\%) }\end{array}$ \\
\hline $\begin{array}{c}\text { Pre- } \\
\text { Installation } \\
\text { 30-Day Test }\end{array}$ & 43 & 3,384 & 0 & 3,384 & 1.25 \\
\hline $\begin{array}{c}\text { DOWS Test: } \\
\text { 10/29/98 to } \\
11 / 15 / 98\end{array}$ & 43.1 & 448 & 1,815 & 2,263 & $\begin{array}{c}8.7 \text { (surface) } \\
1.90 \text { (total) }\end{array}$ \\
\hline
\end{tabular}

Table 4 - Calculated Injection and Recycled Volumes

\begin{tabular}{|c|c|c|c|c|c|}
\hline & Annulus & $\begin{array}{c}\text { Pressure } \\
\text { Drawdown } \\
(830- \\
\text { annulus } \\
\text { pressure) } \\
\text { (psi) }\end{array}$ & $\begin{array}{c}\text { Net Production } \\
\text { (Drawdown } \\
\text { Productivity Index } \\
\text { = Injected Volume) } \\
\text { (bpd) }\end{array}$ & $\begin{array}{c}\text { Recycled } \\
\text { Volume } \\
\text { (bpd) }\end{array}$ & $\begin{array}{c}\text { Injection } \\
\text { Pressure } \\
\text { (psi) }\end{array}$ \\
\hline $11 / 21 / 98$ & 4690 & 1 & 442 & 4,248 & 880 \\
\hline $11 / 23 / 98$ & 4510 & 1 & 442 & 4,068 & 887 \\
\hline $11 / 26 / 98$ & 4571 & 2 & 884 & 3,687 & 899 \\
\hline $11 / 29 / 98$ & 4708 & 4 & 1768 & 2,940 & 880 \\
\hline $11 / 30 / 98$ & 4678 & 8 & 3536 & 1,142 & 881 \\
\hline
\end{tabular}


Table 5 - DOWS Production Statistics

\begin{tabular}{|c|c|c|c|c|c|}
\hline $\begin{array}{c}\text { Production } \\
\text { Period }\end{array}$ & $\begin{array}{c}\text { Average Oil } \\
\text { Production } \\
\text { (bpd) }\end{array}$ & $\begin{array}{c}\text { Average } \\
\text { Water } \\
\text { Produced to } \\
\text { Surface (bpd) } \\
\text { and Percent } \\
\text { of Pre-DOWS } \\
\text { Volume }\end{array}$ & $\begin{array}{l}\text { Average } \\
\text { Water } \\
\text { Injected } \\
\text { (bpd) }\end{array}$ & $\begin{array}{l}\text { Average } \\
\text { Total } \\
\text { Water } \\
\text { Produced } \\
\text { (bpd) }\end{array}$ & $\begin{array}{c}\text { Average } \\
\text { Oil Cut (\%) }\end{array}$ \\
\hline $\begin{array}{c}\text { Pre- } \\
\text { Installation } \\
\text { 30-Day Test }\end{array}$ & 43 & 3,384 & 0.0 & 3,384 & 1.25 \\
\hline $\begin{array}{c}\text { DOWS } \\
\text { Test: } \\
\text { 10/29/98 to } \\
11 / 15 / 98\end{array}$ & 43.1 & $\begin{array}{l}448 \\
13 \%\end{array}$ & 1,815 & 2,263 & $\begin{array}{c}8.7 \text { surface } \\
1.90 \text { total }\end{array}$ \\
\hline \multicolumn{6}{|c|}{ 11/16/98: Acidize Injection Zone to Improve Injectivity } \\
\hline $\begin{array}{c}11 / 29 / 98 \text { to } \\
2 / 17 / 99 \\
\end{array}$ & 10.4 & \begin{tabular}{l|l|}
4.5 \\
$1 \%$ \\
\end{tabular} & 4,500 & 4,500 & $\begin{array}{l}70 \text { surface } \\
0.2 \text { total }\end{array}$ \\
\hline \multicolumn{6}{|c|}{ 2/17/99 to 3/10/99: Tear Down and Replace Corroded Tubing } \\
\hline $\begin{array}{l}\text { Reinstalled } \\
\text { DOWS } \\
3 / 11 / 99 \text { to } \\
3 / 22 / 99\end{array}$ & 16 & $\begin{array}{l}270 \\
8 \%\end{array}$ & 3,004 & 3,274 & $\begin{array}{c}5.6 \text { surface } \\
0.5 \text { total } \\
\text { (1.0 undiluted) }\end{array}$ \\
\hline $\begin{array}{c}3 / 23 / 99 \text { to } \\
9 / 15 / 99\end{array}$ & 11.4 & $\begin{array}{l}253 \\
8 \%\end{array}$ & 3,053 & 3,306 & $\begin{array}{c}4.5 \text { surface } \\
0.3 \text { total } \\
(0.6 \text { undiluted })\end{array}$ \\
\hline $\begin{array}{l}9 / 16 / 99 \text { to } \\
12 / 10 / 99\end{array}$ & 9.0 & $\begin{array}{l}260 \\
8 \%\end{array}$ & 3,439 & 3,699 & $\begin{array}{c}3.5 \text { surface } \\
0.2 \text { total } \\
(0.4 \text { undiluted })\end{array}$ \\
\hline
\end{tabular}




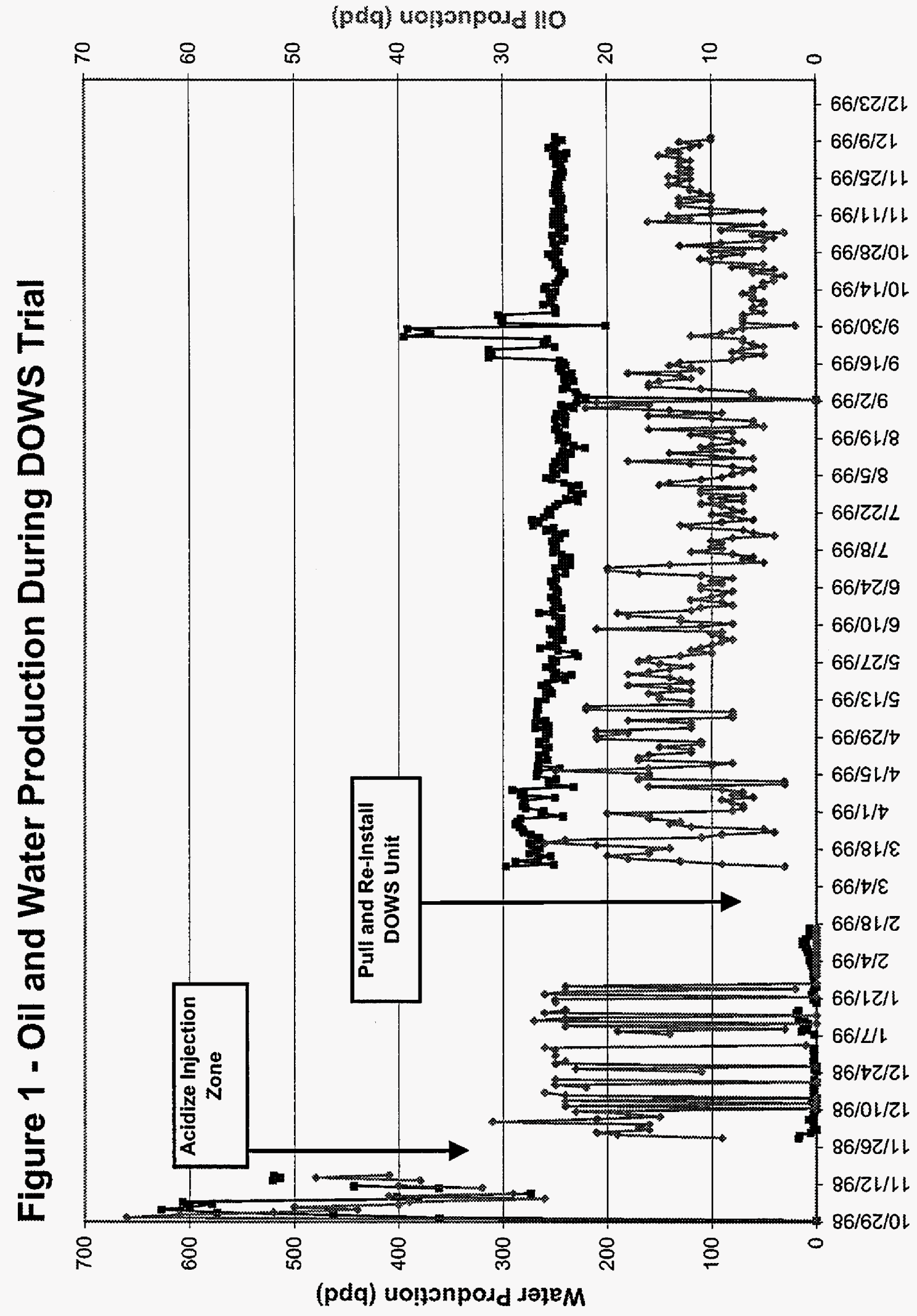




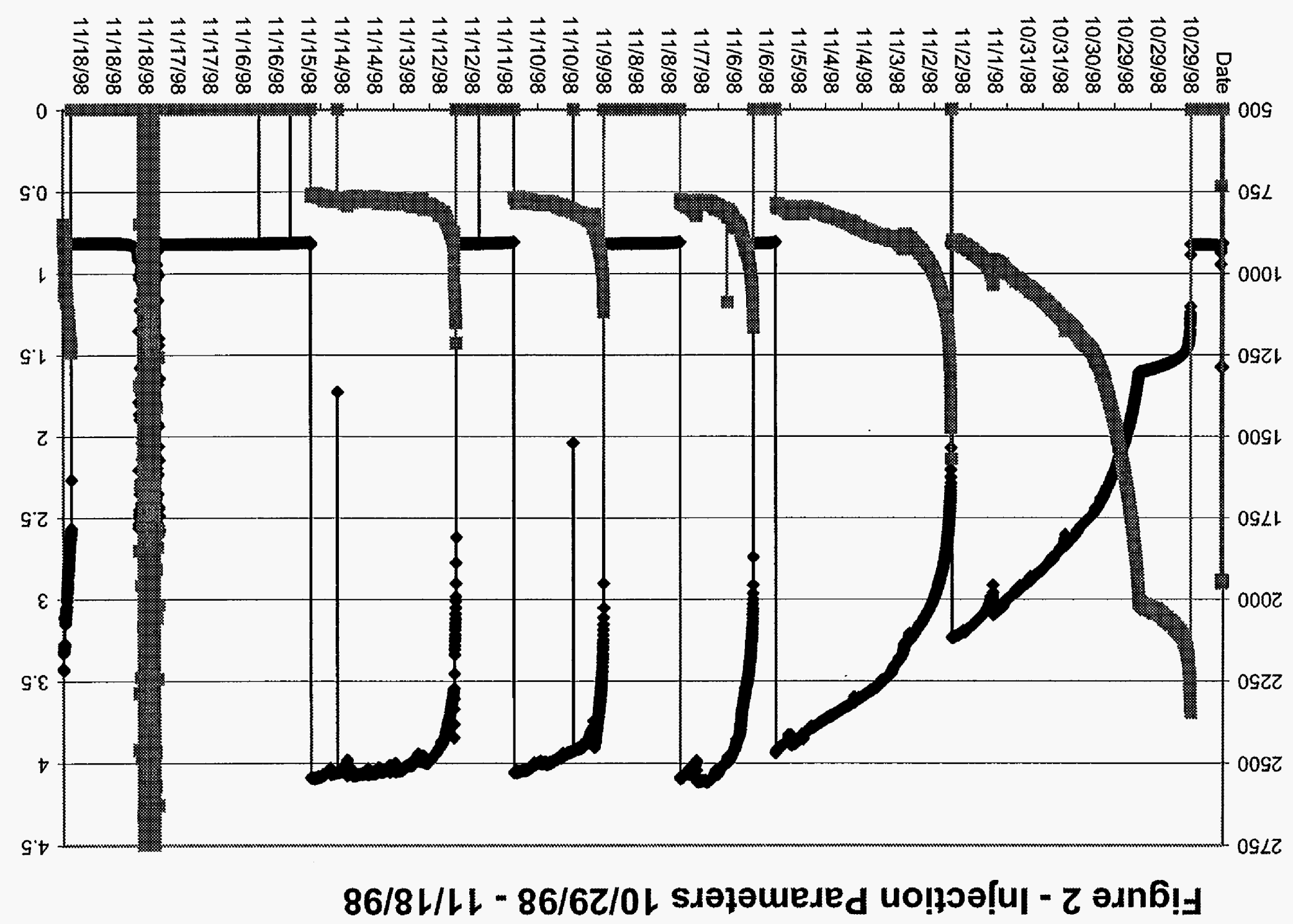




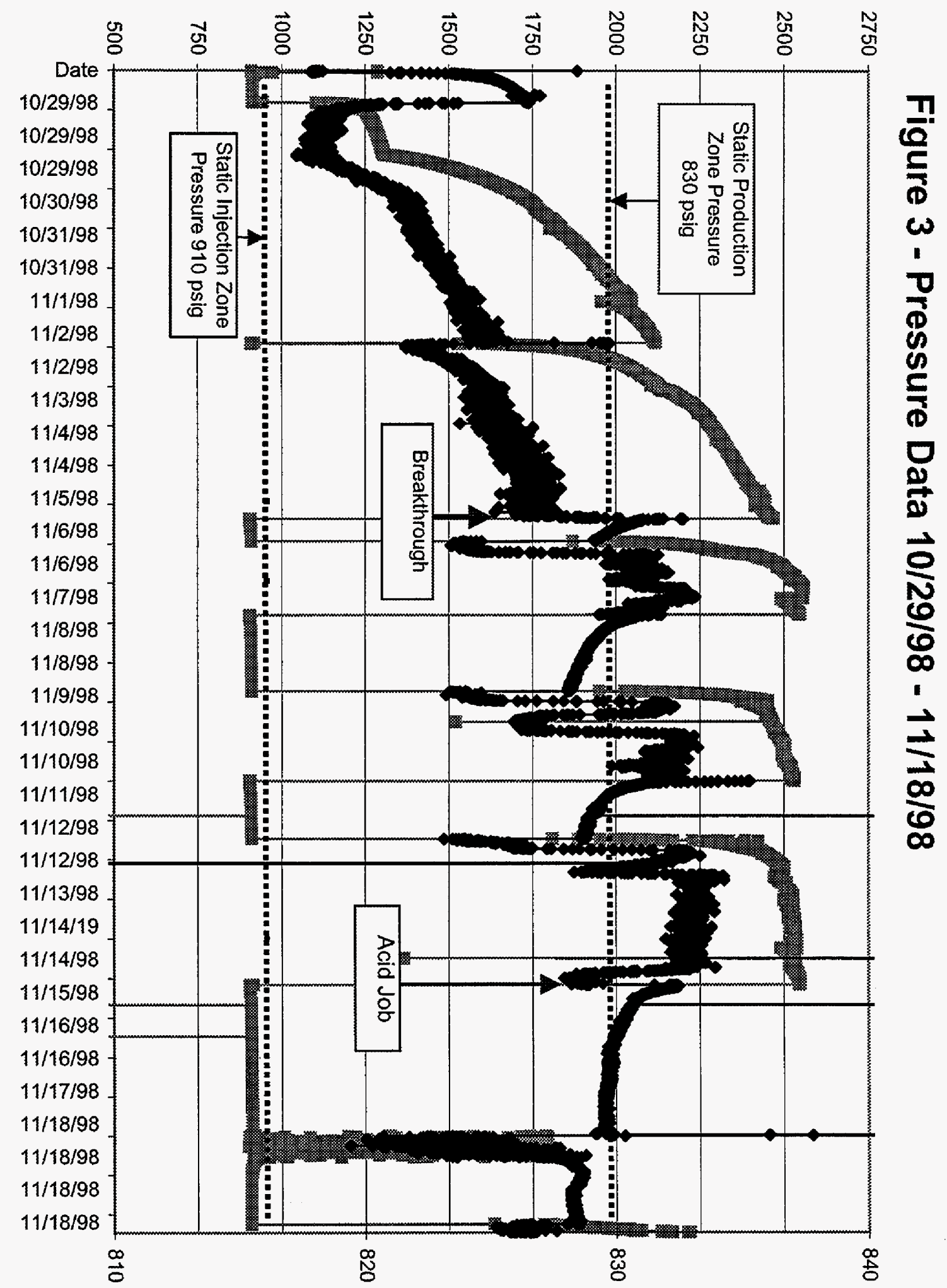




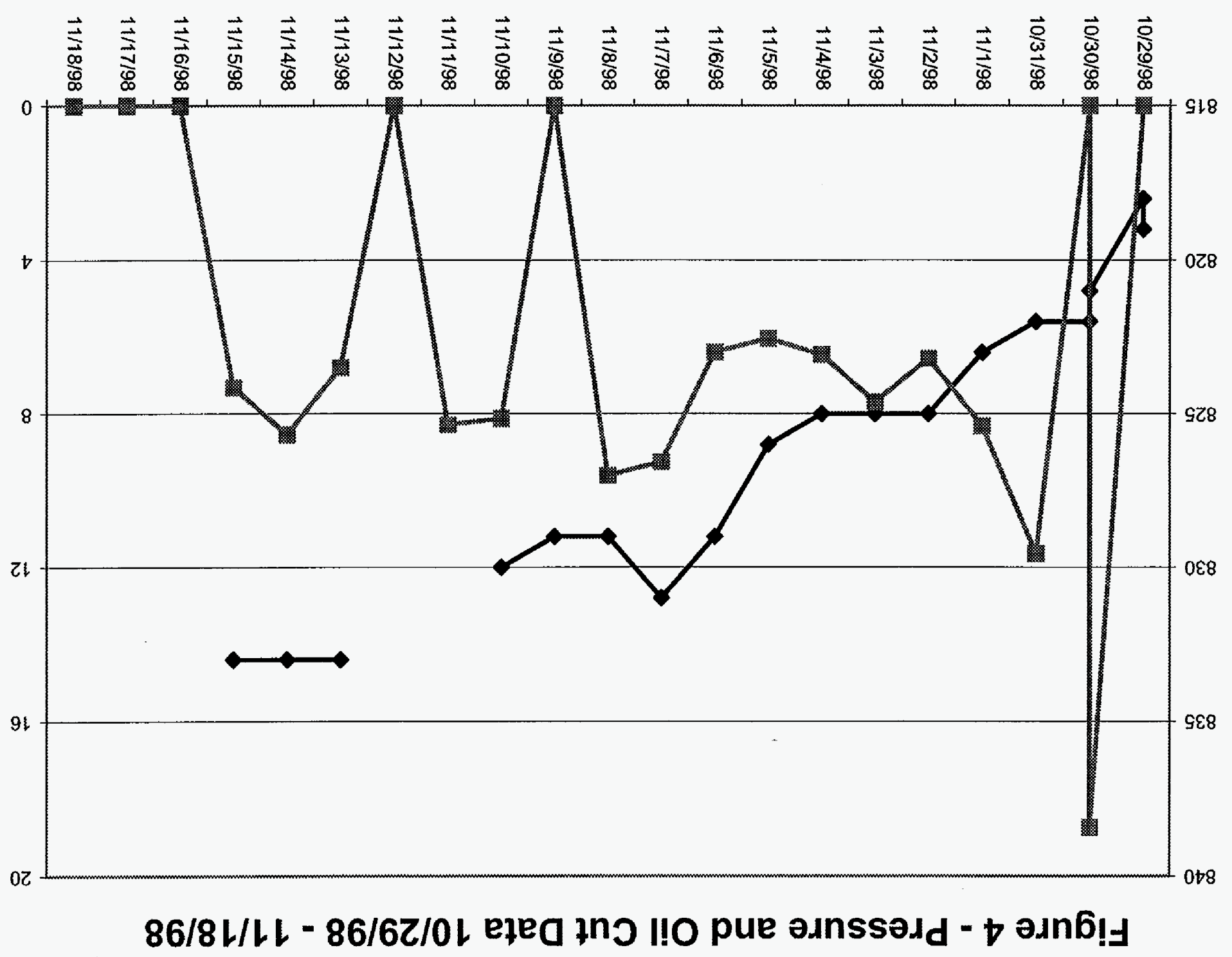




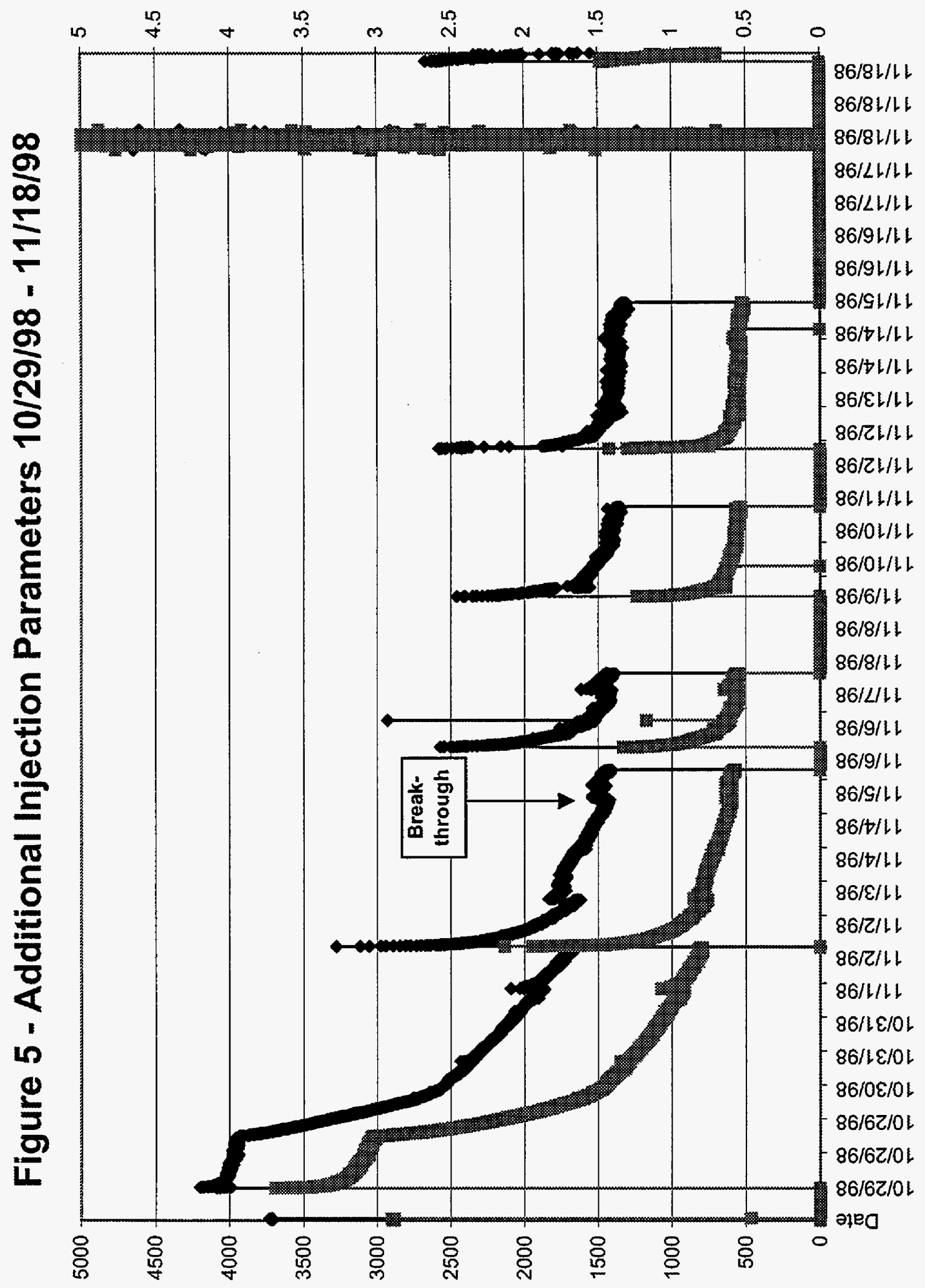




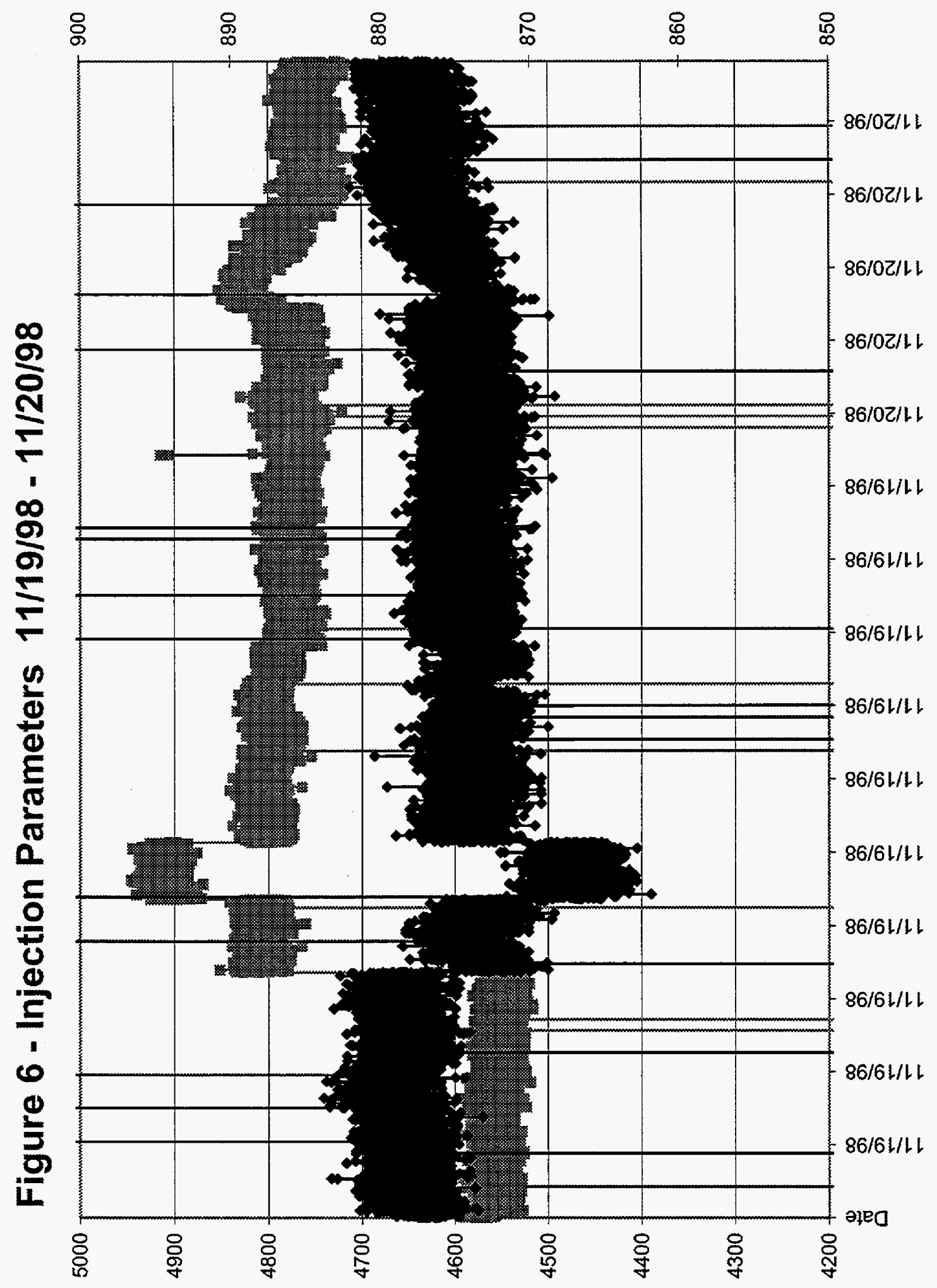




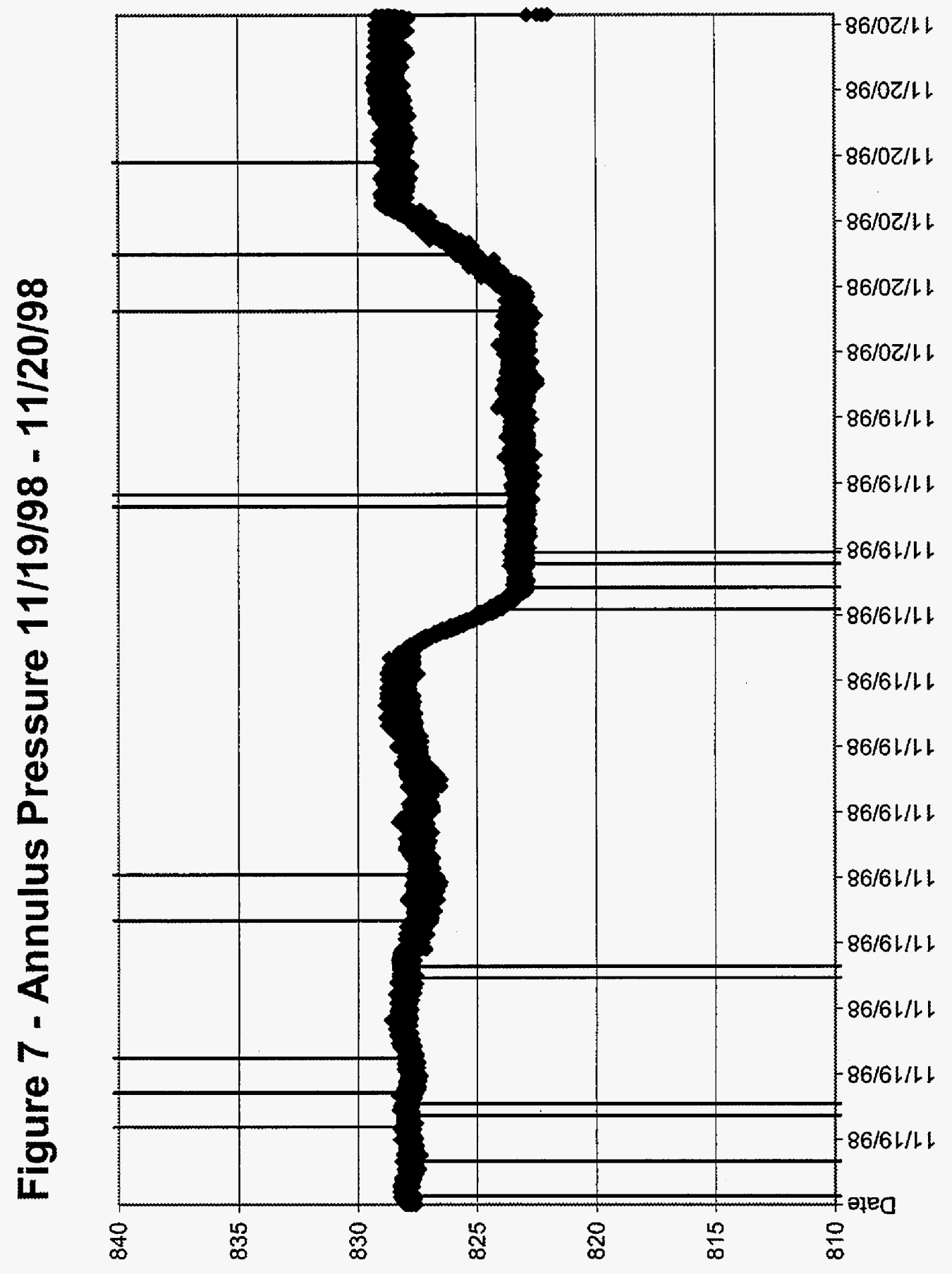




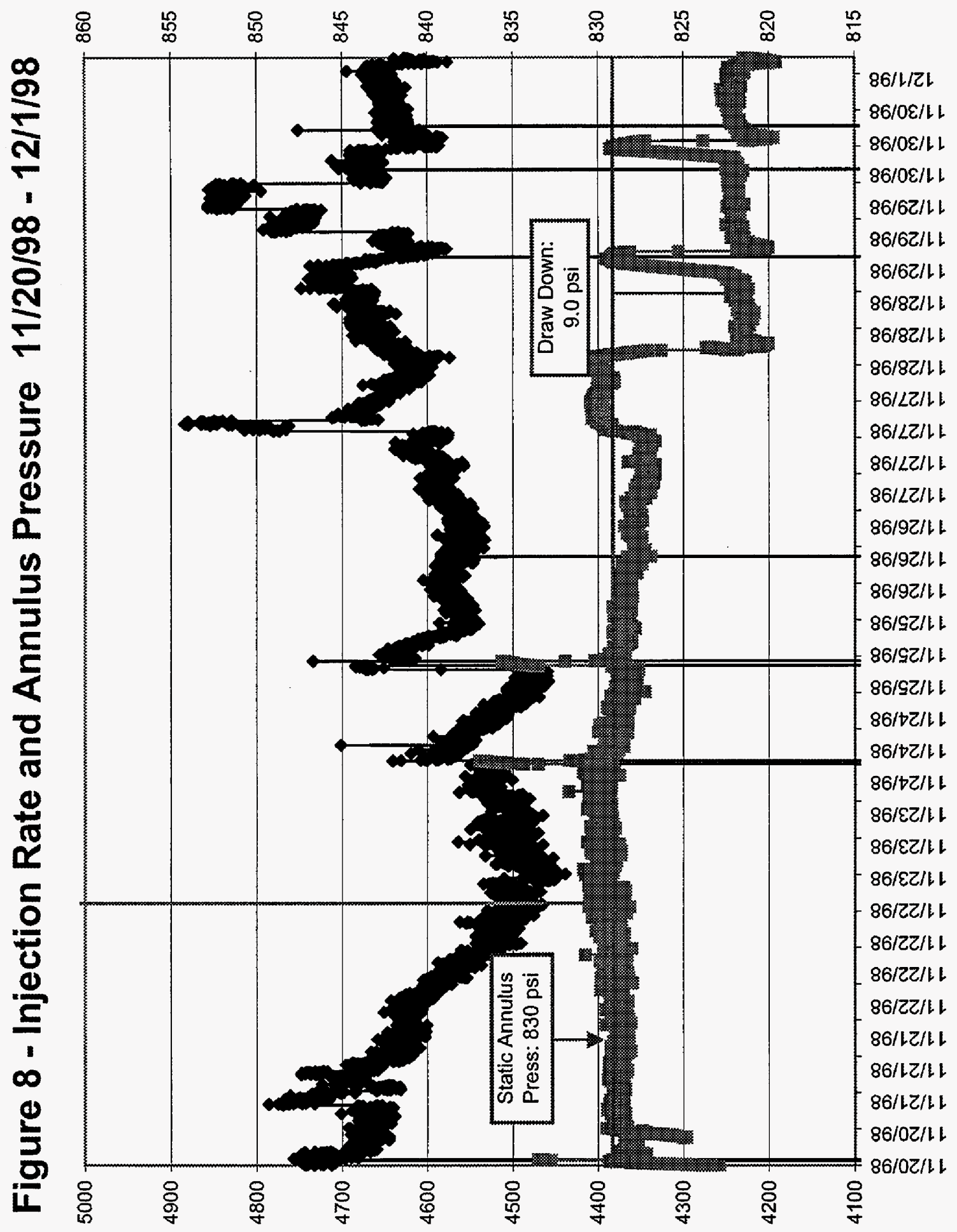




\section{Figure 9 - Injection Rate and Annulus Pressure 12/1/98 - 12/7/98}

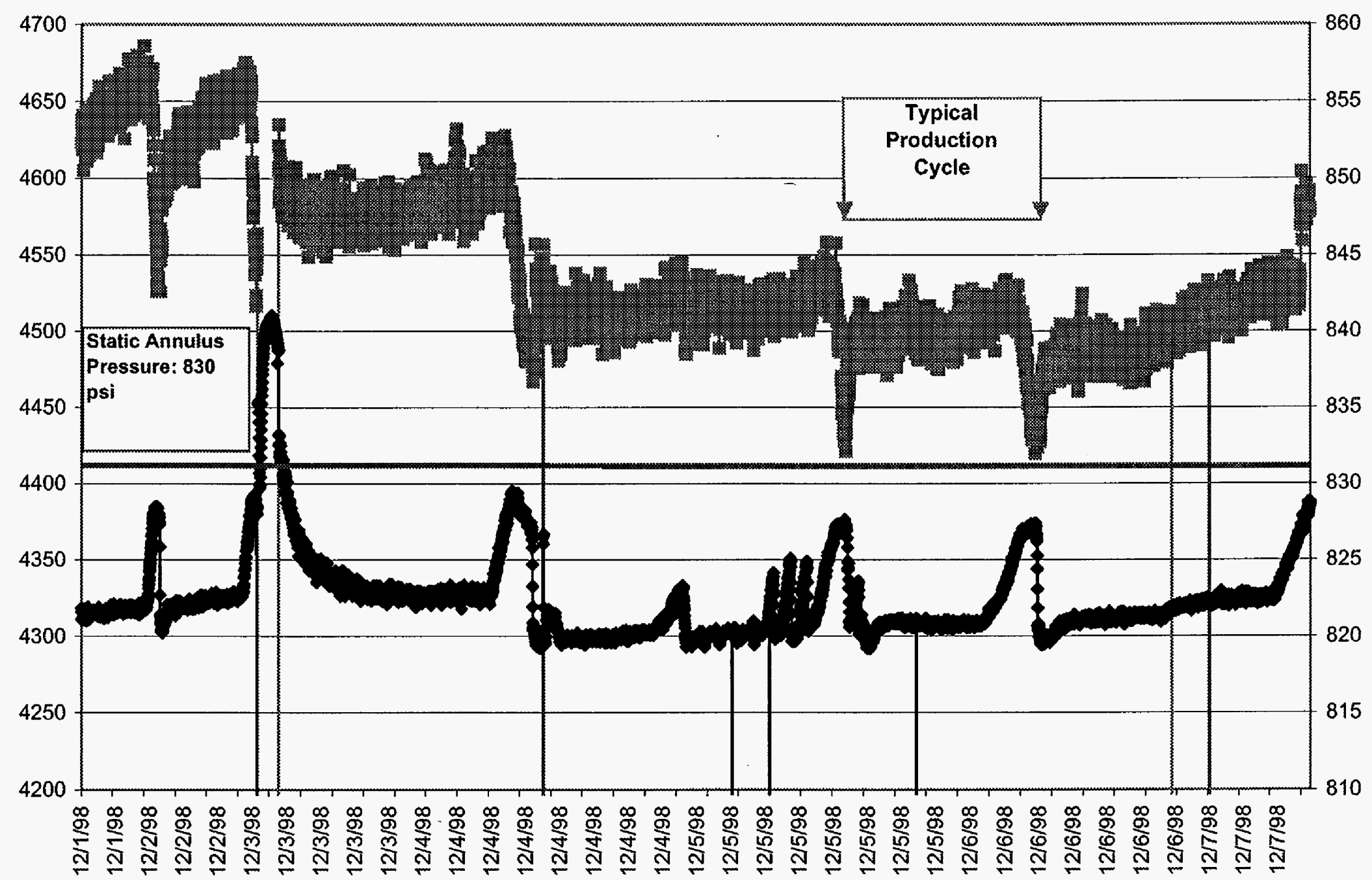


Figure 10 - Apparent Injectivity 12/1/98 - 12/7/98

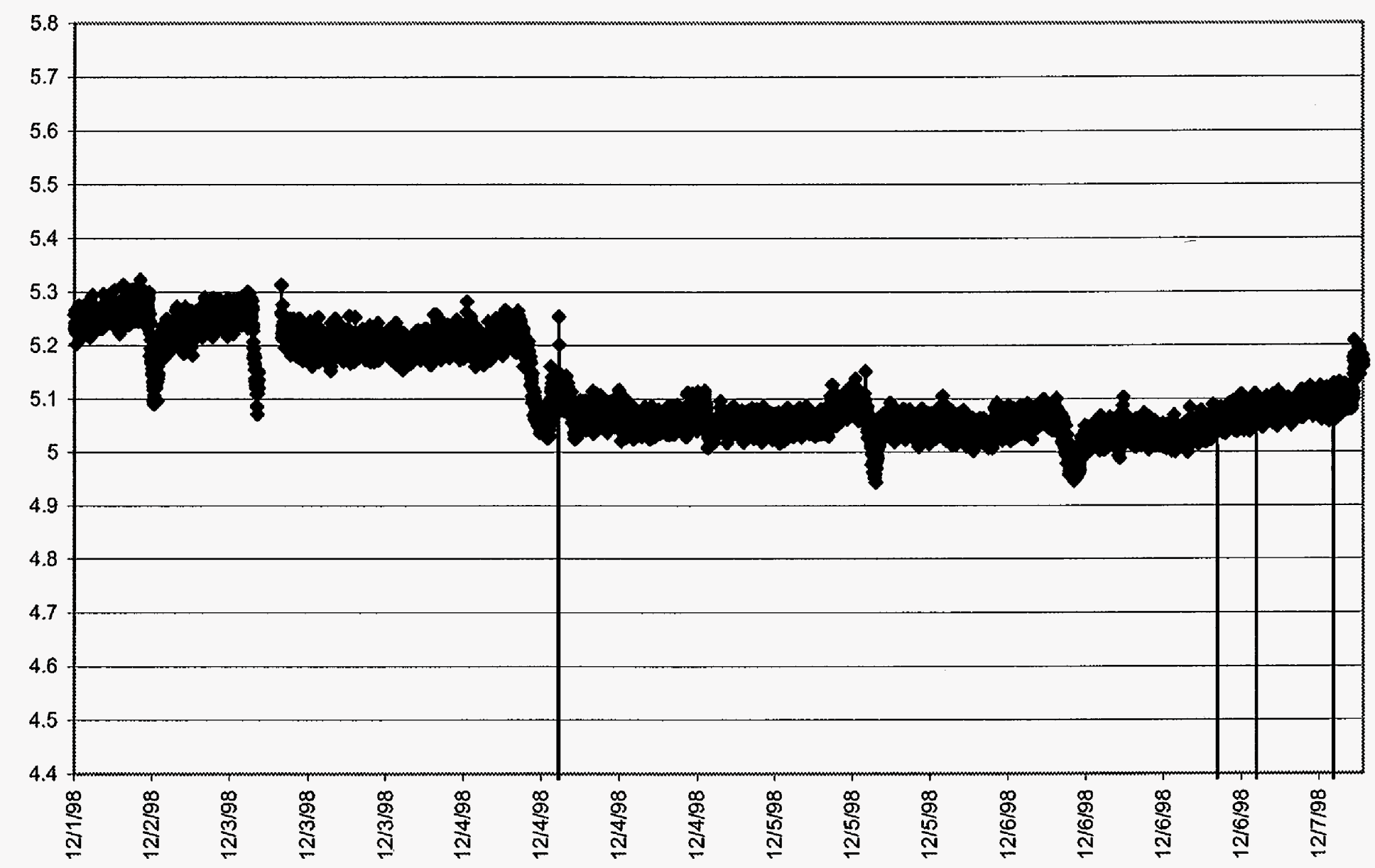




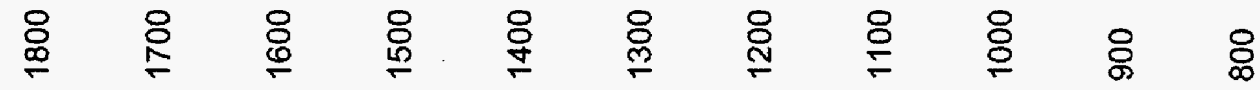

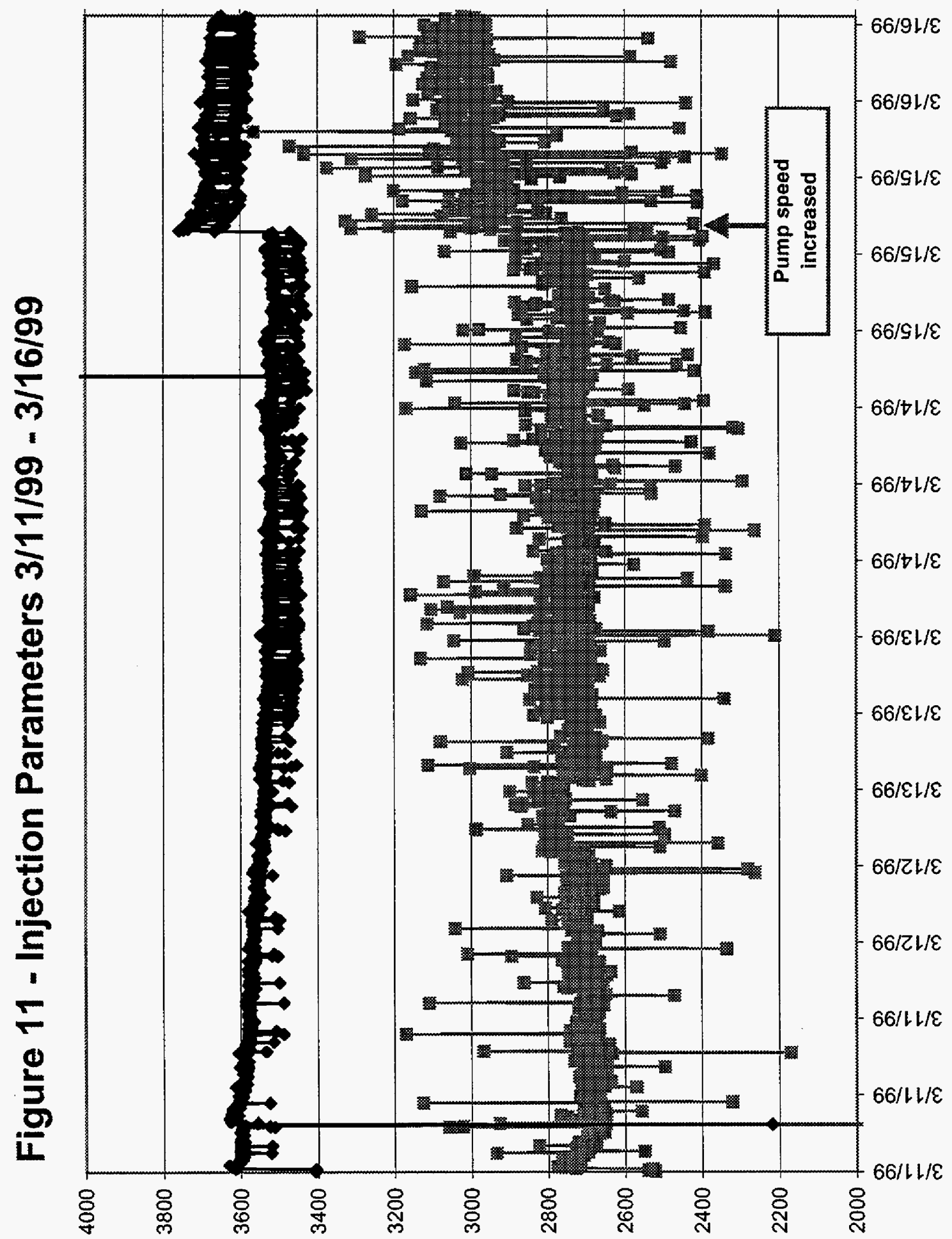




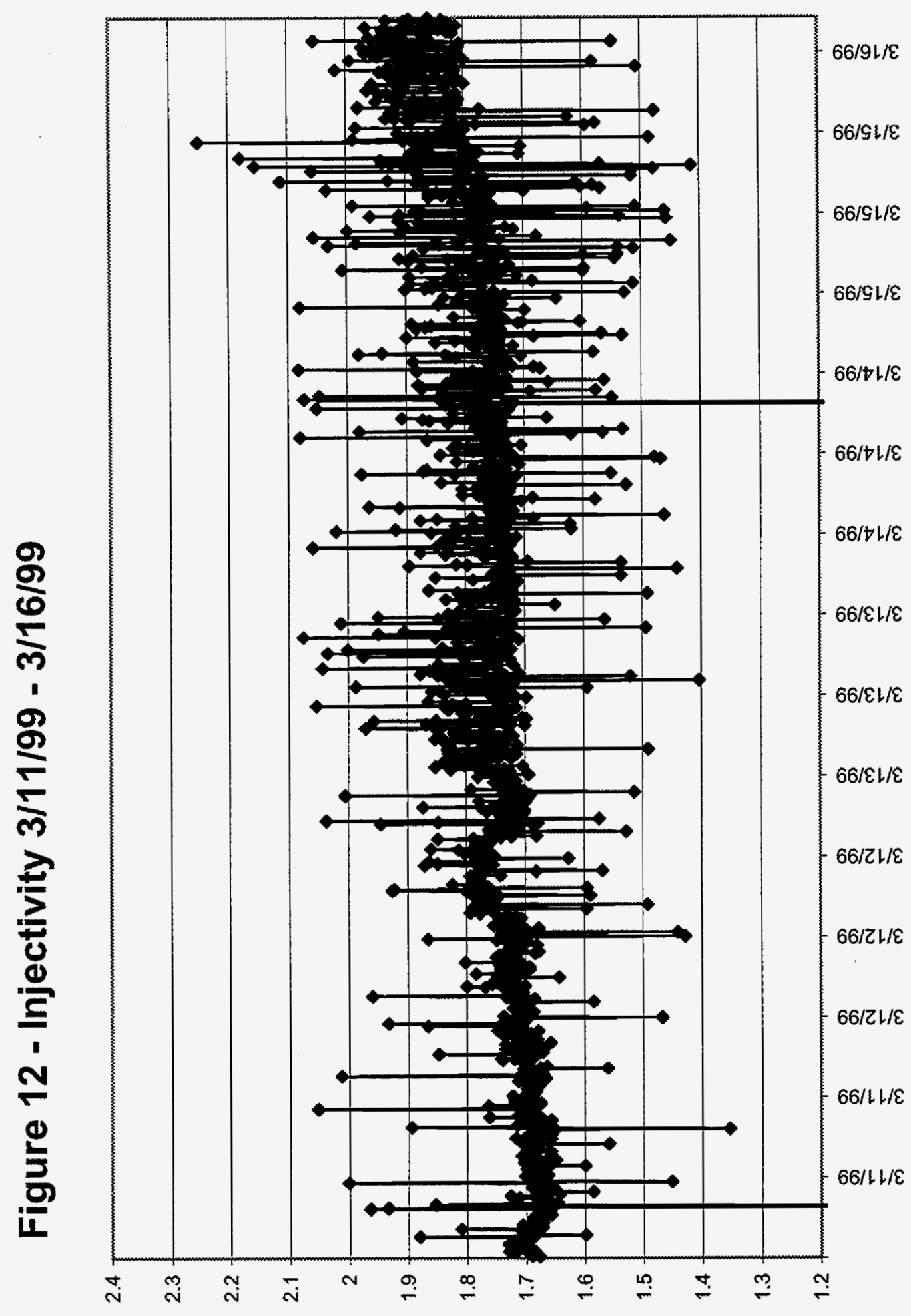




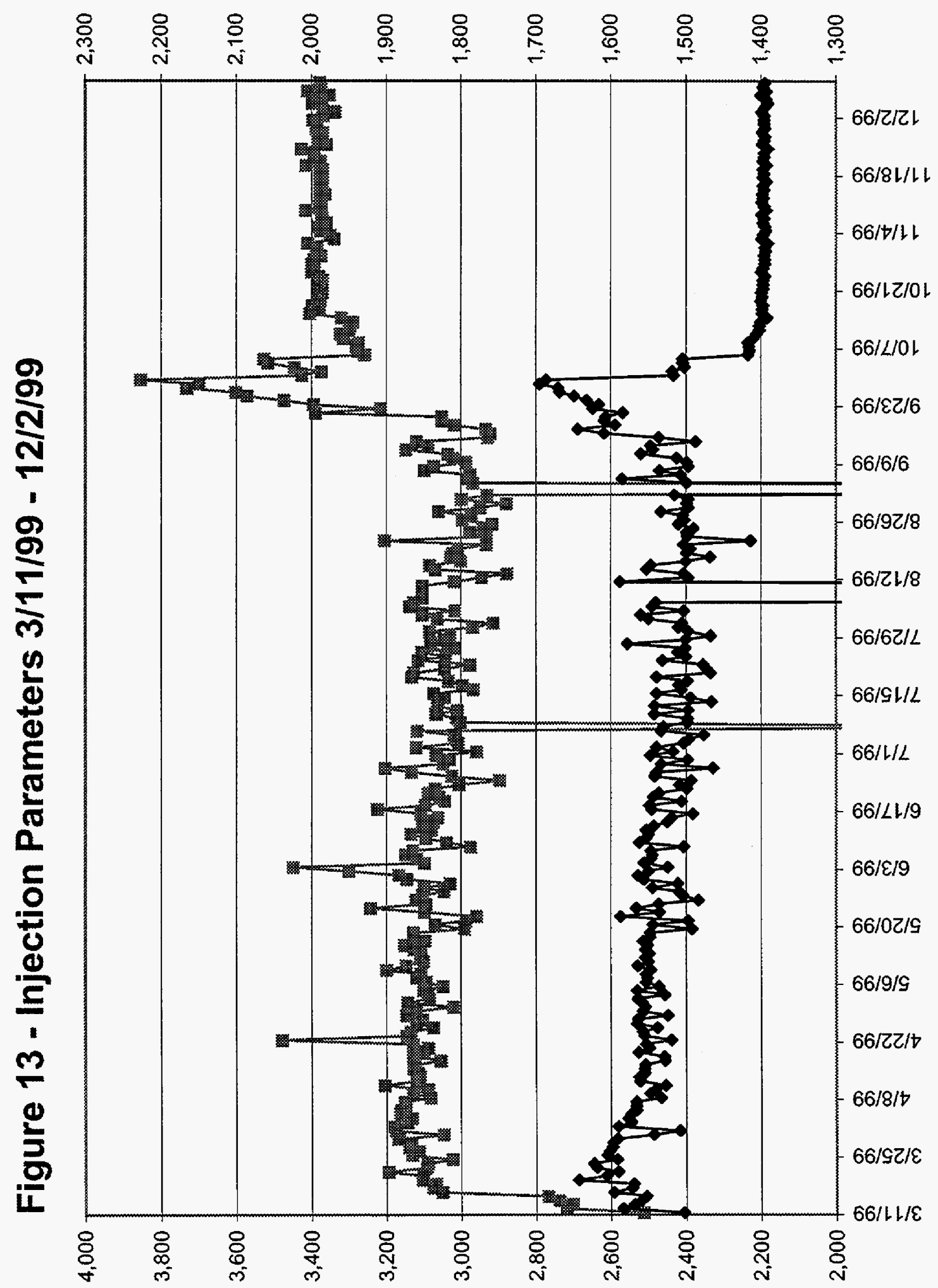




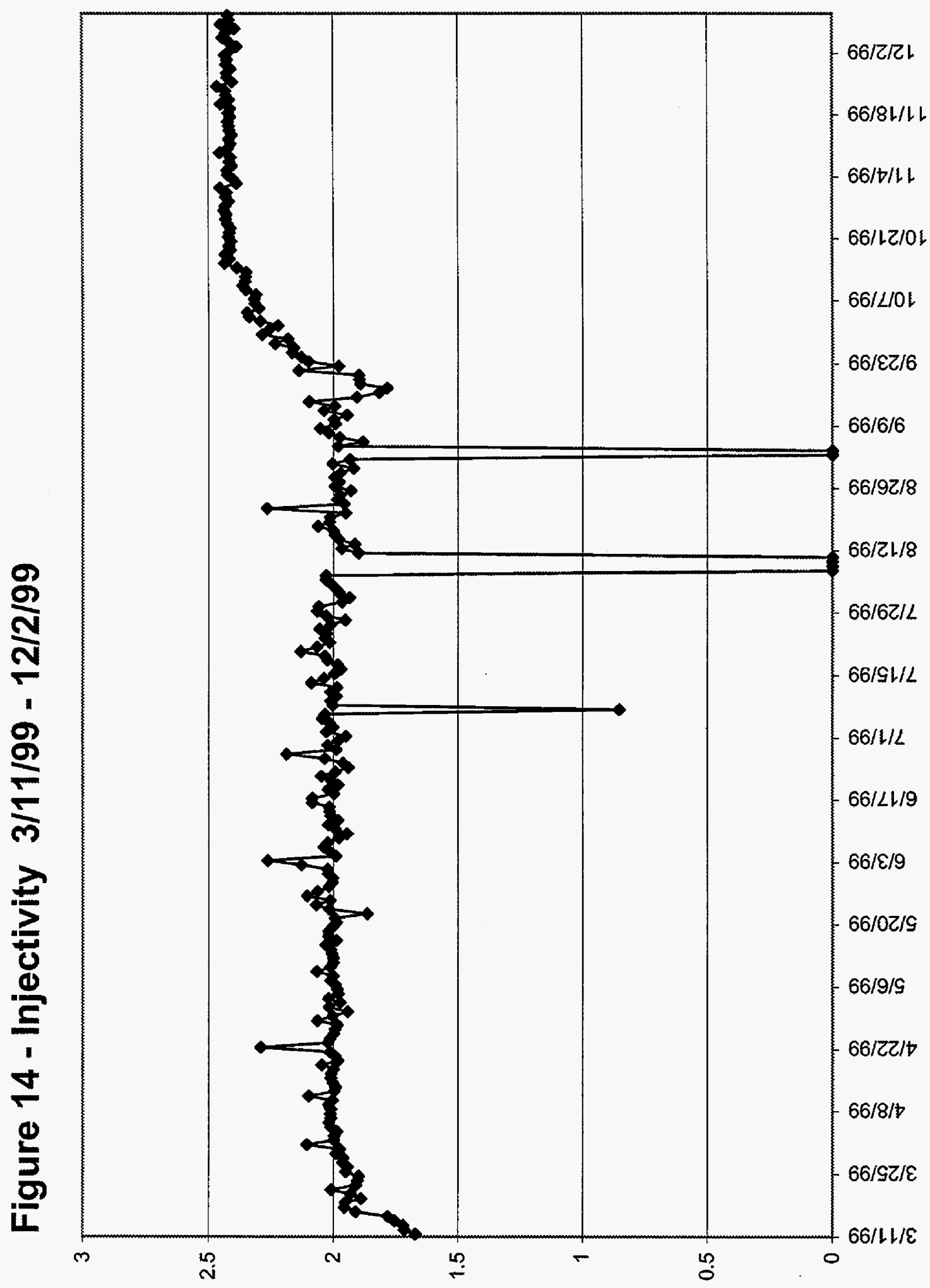




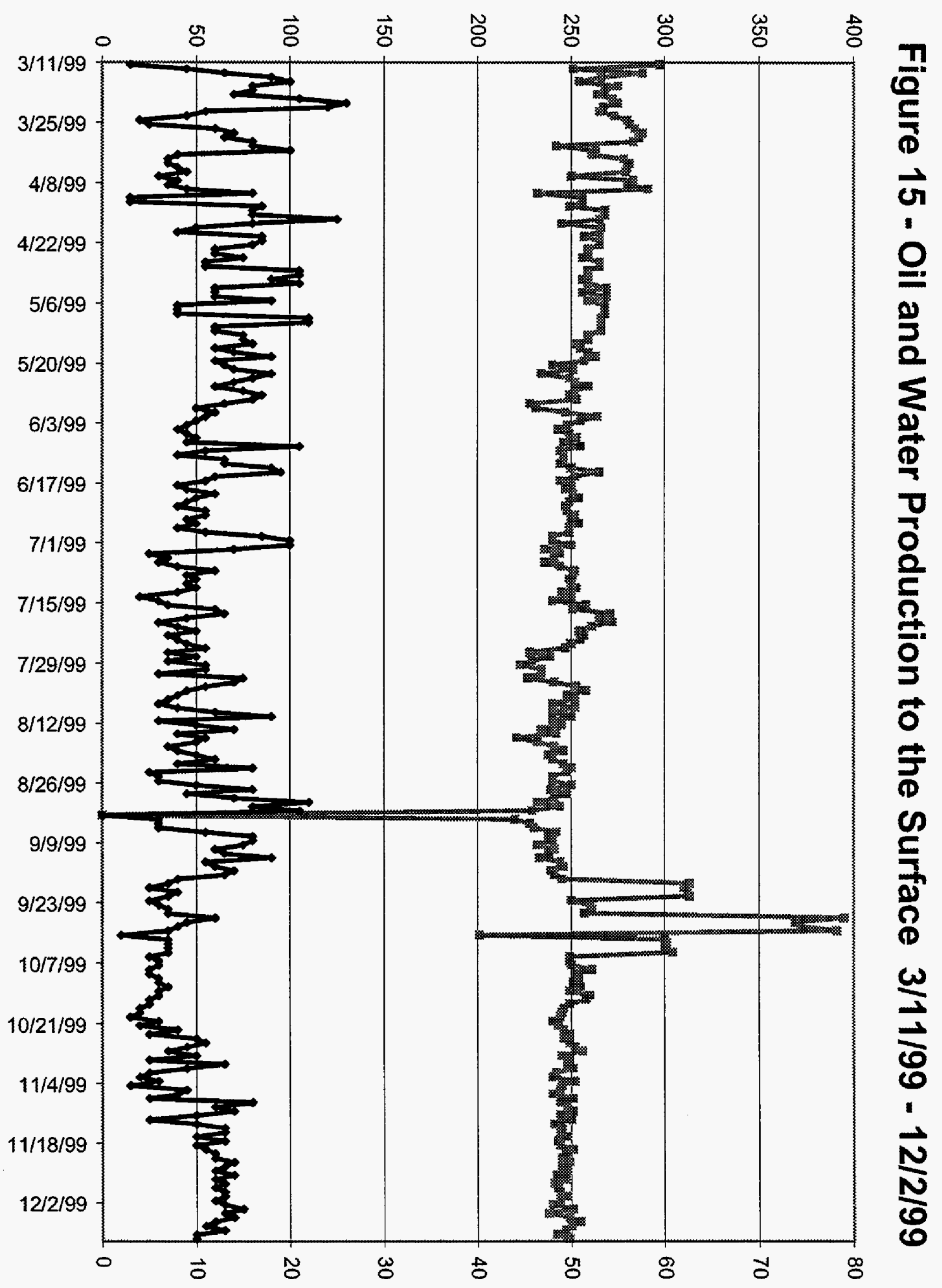




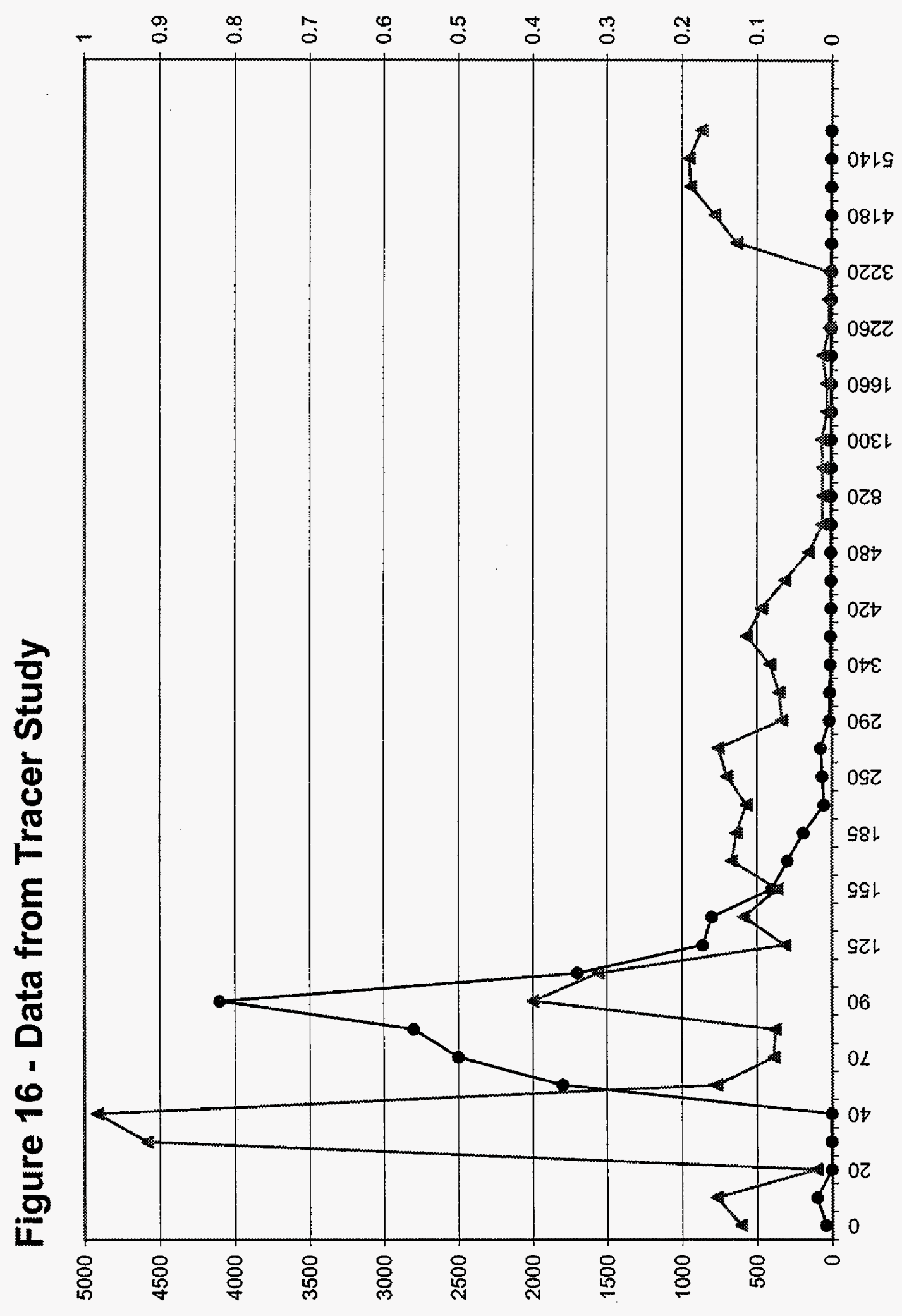




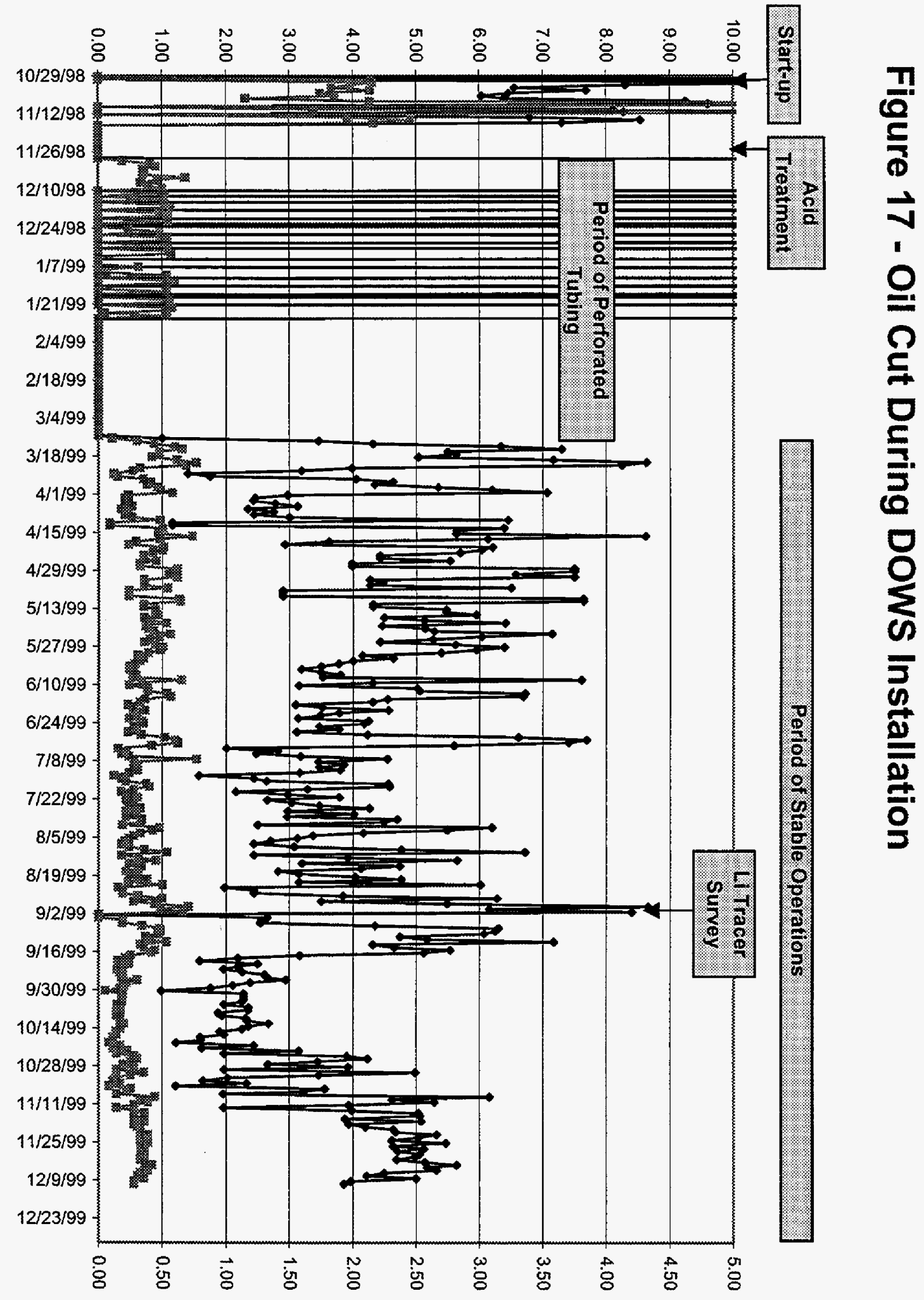


